\title{
Soils Infiltration Data for Selected Wyoming Watersheds, 1998-1999
}

By Kirk Miller, John Elliott, and Nolan Friday

Prepared in cooperation with the

WYOMING DEPARTMENT OF TRANSPORTATION

Open-File Report 2005-1322

U.S. Department of the Interior

U.S. Geological Survey 


\section{U.S. Department of the Interior \\ Gale A. Norton, Secretary \\ U.S. Geological Survey \\ P. Patrick Leahy, Acting Director}

U.S. Geological Survey, Reston, Virginia: 2005

For sale by U.S. Geological Survey, Information Services
Box 25286, Denver Federal Center
Denver, CO 80225
For more information about the USGS and its products:
Telephone: 1-888-ASK-USGS
World Wide Web: http://www.usgs.gov/

Any use of trade, product, or firm names in this publication is for descriptive purposes only and does not imply endorsement by the U.S. Government.

Although this report is in the public domain, permission must be secured from the individual copyright owners to reproduce any copyrighted materials contained within this report.

Suggested citation:

Miller, K.A., Elliott, John, and Friday, Nolan, 2005, Soils Infiltration Data for Selected Wyoming Watersheds, 19981999: Cheyenne, Wyoming, U.S. Geological Survey Open-File Report 2005-1322, 74 p. 


\section{Contents}

Abstract
Introduction
$\quad$ Purpose and Scope
Previous Investigations
Acknowledgements
Methods
Rescription of Infiltration Tests
Appendix 1. Graphs of Infiltration Data
Appendix 2. Infiltration Data

\section{Figures}

1. Map showing location of infiltration test sites, Wyoming, 1998-99.................................. 3

2. Schematic diagram and construction specifications for double-ring infiltrometer......... 7

3. Schematic of infiltration measurement equipment ......................................................... 8 Appendix figures:

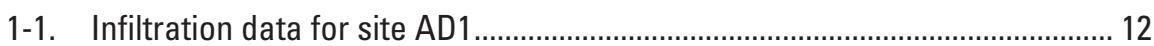

1-2. Infiltration data for site AD2

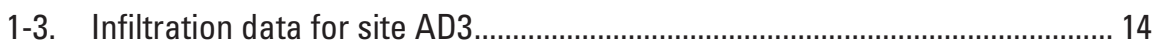

1-4. Infiltration data for site ARS1 ....................................................................... 15

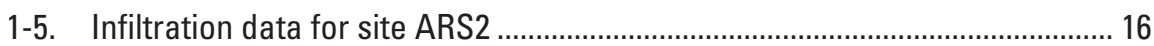

1-6. Infiltration data for site ARS3 ........................................................................... 17

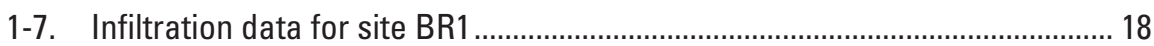

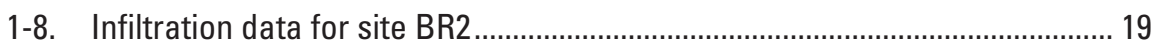

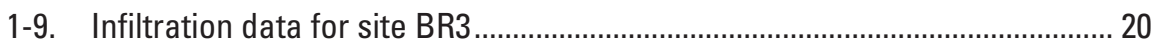

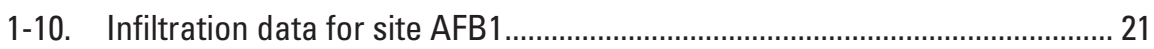

1-11. Infiltration data for site AFB2

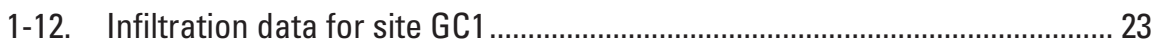

1-13. Infiltration data for site GC2

1-14. Infiltration data for site GC3 ................................................................... 25

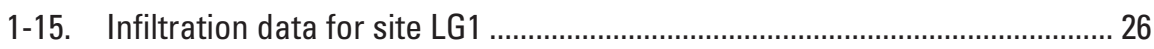

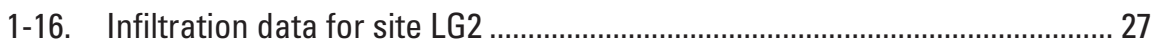

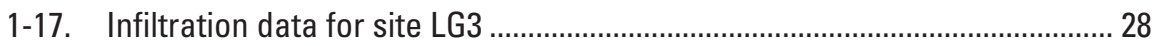

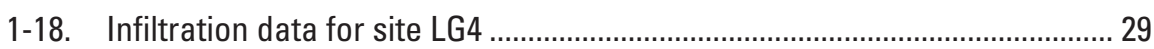

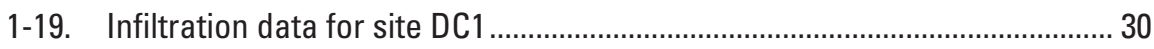

1-20. Infiltration data for site DC2

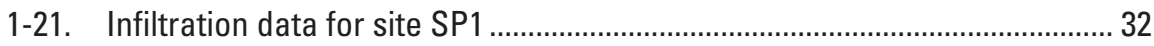

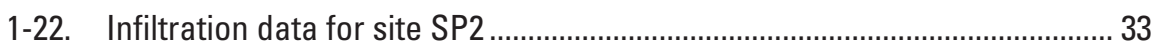

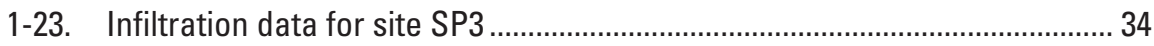




\section{Tables}

1. Locations, identifiers, and dates of infiltration tests ..................................................... 2

2. Description of infiltration test site soil and vegetation properties ................................... 4

3. Description of NRCS hydrologic soil groups................................................................... 5

4. Description of NRCS antecedent soil moisture conditions .............................................. 5

Appendix tables:

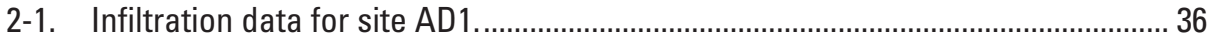

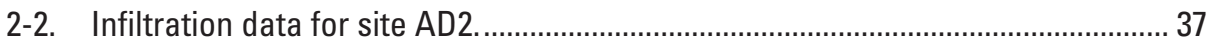

2-3. Infiltration data for site AD3 ............................................................................... 38

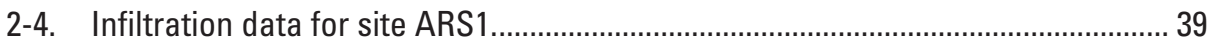

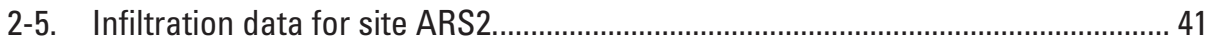

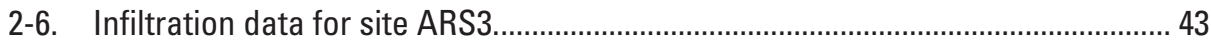

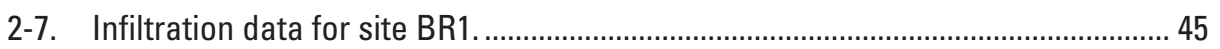

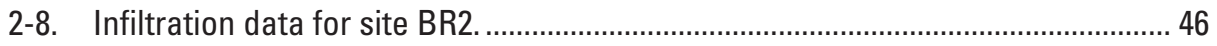

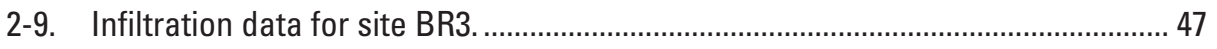

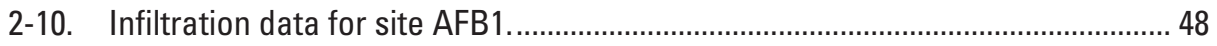

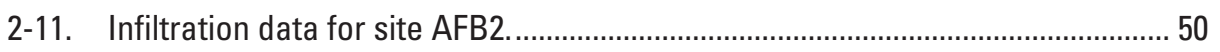

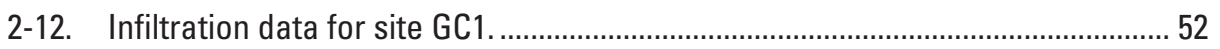

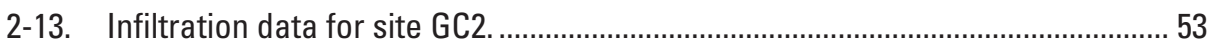

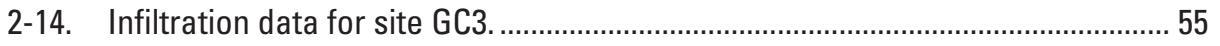

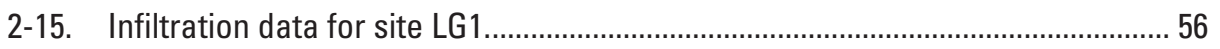

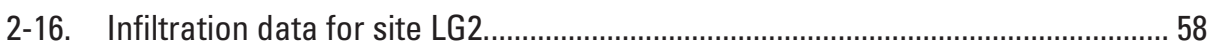

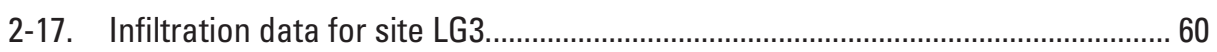

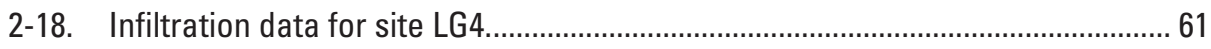

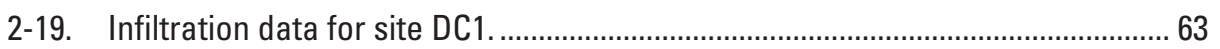

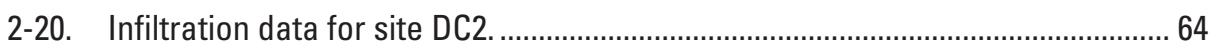

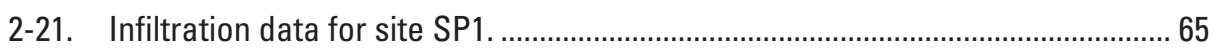

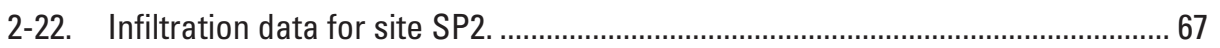

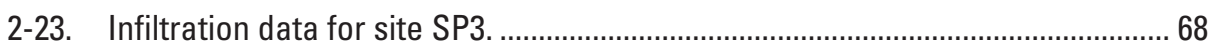




\section{Conversion Factors and Datum}

\begin{tabular}{lcl}
\hline Multiply & By & To obtain \\
\hline & Length & \\
centimeter $(\mathrm{cm})$ & 0.3937 & inch (in.) \\
millimeter $(\mathrm{mm})$ & 0.03937 & inch (in.) \\
meter $(\mathrm{m})$ & 3.281 & foot $(\mathrm{ft})$ \\
\hline & Area & \\
square centimeter $\left(\mathrm{cm}^{2}\right)$ & 0.155 & square inch $\left(\mathrm{in}^{2}\right)$ \\
\hline & Volume & \\
liter $(\mathrm{L})$ & 0.26 & gallons $(\mathrm{gal})$ \\
milliliter $(\mathrm{mL})$ & 0.026 & gallons (gal) \\
\hline & Mass & \\
kilogram $(\mathrm{kg})$ & 2.205 & pound, avoirdupois $(\mathrm{lb})$ \\
\hline & Flow rate & \\
centimeters per hour $(\mathrm{cm} / \mathrm{hr})$ & 0.3937 & inches per hour $(\mathrm{in} / \mathrm{hr})$ \\
\hline
\end{tabular}

Temperature in degrees Celsius $\left({ }^{\circ} \mathrm{C}\right)$ may be converted to degrees Fahrenheit $\left({ }^{\circ} \mathrm{F}\right)$ as follows:

$$
{ }^{\circ} \mathrm{F}=\left(1.8 \times{ }^{\circ} \mathrm{C}\right)+32
$$

Temperature in degrees Fahrenheit $\left({ }^{\circ} \mathrm{F}\right)$ may be converted to degrees Celsius $\left({ }^{\circ} \mathrm{C}\right)$ as follows:

$$
{ }^{\circ} \mathrm{C}=\left({ }^{\circ} \mathrm{F}-32\right) / 1.8
$$

Horizontal coordinate information is referenced to the North American Datum of 1983 (NAD 83) 



\title{
Soils Infiltration Data for Selected Wyoming Watersheds, 1998-1999
}

\author{
By Kirk Miller, John Elliott, and Nolan Friday
}

\begin{abstract}
Soils infiltration data collected during 1998-1999 are summarized for watersheds near Cheyenne, Casper, Sheridan, and Gillette, Wyoming. Incremental infiltration rates are calculated for each infiltration test from flow-rates needed to maintain a constant head in a double-ring infiltrometer. Site vegetative cover and condition, soil antecedent moisture condition, and published soils data are summarized for each test site.
\end{abstract}

\section{Introduction}

The Wyoming Department of Transportation (WYDOT) uses mathematical models to design and evaluate bridges and culverts. Various climatologic, physiographic, hydrologic, and hydraulic data are required as model input and for model calibration. Soils infiltration data can be used for model calibration. In addition, soils infiltration data are useful for other hydrologic analyses and models employed by the U.S. Geological Survey (USGS). In cooperation with the WYDOT, the USGS collected infiltration and relevant ancillary data for selected watersheds in Wyoming in 1998 and 1999.

\section{Purpose and Scope}

This report presents soils infiltration data measured at 23 sites in seven Wyoming watersheds during 1998 and 1999. Incremental infiltration rate data tables and plots are included as appendixes. Site soil names and hydrologic soil groups are from the U.S. Department of Agriculture (USDA) (1995, 1997, 1998, 2005a, 2005b). Vegetation cover and condition information are field observations recorded at the time the infiltration measurements were made. Further reduction, analysis, and interpretation of these data are beyond the scope of this report.

\section{Previous Investigations}

The USGS previously has collected infiltration data in Wyoming. Infiltration data for "a variety of wild natural undisturbed soils in Colorado, Wyoming, and Montana" are summarized in McQueen (1963). Data were collected using a USGS-designed rainfall-simulator infiltrometer ("microrainulator"). Mean infiltration rates from four or more tests averaged over the 40- to 60-minute test intervals ranged from $0.58 \mathrm{in} / \mathrm{hr}(1.5 \mathrm{~cm} / \mathrm{hr}$; shale-soil type) to $3.64 \mathrm{in} / \mathrm{hr}(9.2 \mathrm{~cm} / \mathrm{hr}$; sandy-soil type).

Rankl (1990) also measured infiltration rates using the USGS microrainulator described by McQueen (1963). The data were collected from two watersheds for comparison of infiltration rates within a basin. Adjusted (for lateral movement) incremental infiltration rates ranged from $0.61 \mathrm{in} / \mathrm{hr}$ $(1.5 \mathrm{~cm} / \mathrm{hr}$; silty clay to clay loam) to $0.82 \mathrm{in} / \mathrm{hr}(2.1 \mathrm{~cm} / \mathrm{hr}$; fine sandy-loam) after 1 hour.

Infiltration data previously have been collected in Wyoming by others. In particular, Abdel-Magid and others (1987) summarized infiltration data from 1983-1984 in an area also tested during this study. Mean infiltration rates determined from the final 30 minutes of the 2-hour tests ranged from 3.1 to $4.0 \mathrm{in} / \mathrm{hr}$ ( 7.87 to $10.15 \mathrm{~cm} / \mathrm{hr}$; sandy loam). Frasier and others (1995) studied infiltration characteristics at the same site in 1993; those data were not available at the time of this study. The USDA Natural Resources Conservation Service (NRCS) has more information on these and other infiltration data collected in Wyoming.

\section{Acknowledgements}

William Bailey, WYDOT, is acknowledged for assisting in the design of the data collection efforts. George Davis, Glen Mitchell, and Abe Stevenson, NRCS, are acknowledged for providing expert advice, opinions, and ancillary soils information. 


\section{Methods}

Infiltration data were collected from seven small watersheds across the State. Those watersheds were Childs Draw, Allison Draw, and Dry Creek (Cheyenne); Garden Creek (Casper); Little Goose Creek (Sheridan); and Stonepile and Donkey Creeks (Gillette). One or more sites representative of the dominant physical characteristics of each watershed were selected based on field reconnaissance. Access also was a primary consideration in site selection; areas were selected to minimize effects to private landowners and maximize future data collection efforts. Data were collected at two to three locations in each watershed. Where possible, site locations were determined using a global positioning satellite (GPS) unit. Site locations are shown in figure 1; map and site identifiers, location data, and test dates for each watershed are listed in table 1.

A general description of each site was prepared. Soils information for each site was obtained from NRCS published or digital sources. Mapping units, or mapping unit identifiers (MUIDs) were determined by plotting each site location on
NRCS soils maps. Using the MUID, the soil name (or other taxon) and slope range were determined from related attribute tables. Field observations of vegetation type and condition were recorded. Soils information and field observations for the test sites are listed in table 2.

Hydrologic soil groups were determined from related attribute tables by using the MUID. Soils are classified into hydrologic soil groups by the minimum infiltration rate obtained for bare soil after prolonged wetting (U.S.Department of Agriculture, 1986). For complex soil names, the convention is to list the dominant soil first. The hydrologic soil group listing follows the same convention. Relative infiltration rates and general descriptions of soil hydrologic properties as defined by the NRCS are presented in table 3 for the reader's convenience.

Soil moisture content is important in evaluating infiltration data. Quantitative soil moisture content was not determined for each site. However, field observations were compiled and equivalent NRCS qualitative antecedent soil moisture conditions (AMC) (table 4) were determined. For all the infiltration tests except BR1, a soil moisture condition

Table 1. Locations, identifiers, and dates of infiltration tests.

[Map identifier references figure 1; Location latitude and longitude in degrees minutes seconds; N/A, not applicable; —, no data.]

\begin{tabular}{|c|c|c|c|c|c|c|c|}
\hline \multirow{2}{*}{$\begin{array}{c}\text { Nearest } \\
\text { town }\end{array}$} & \multirow{2}{*}{$\begin{array}{c}\text { Map } \\
\text { identifier }\end{array}$} & \multirow[b]{2}{*}{ Watershed } & \multirow{2}{*}{$\begin{array}{c}\text { Site } \\
\text { identifier }\end{array}$} & \multicolumn{2}{|c|}{ Location } & \multirow[b]{2}{*}{ Relative location } & \multirow[b]{2}{*}{ Date } \\
\hline & & & & Latitude & Longitude & & \\
\hline Cheyenne & 1 & Allison Draw & $\mathrm{AD} 1$ & 410423.46 & 1045016.16 & N/A & $09 / 15 / 1998$ \\
\hline Cheyenne & 2 & Allison Draw & AD2 & 410423.41 & 1045014.52 & $\sim 130 \mathrm{ft}$ NE of AD1 & 09/16/1998 \\
\hline Cheyenne & 3 & Allison Draw & AD3 & 410423.41 & 1045014.52 & $36 \mathrm{ft} \mathrm{NE}$ of AD2 & 09/16/1998 \\
\hline Cheyenne & 4 & Childs Draw & ARS1 & 411240.49 & 1045114.96 & N/A & 09/17/1998 \\
\hline Cheyenne & 5 & Childs Draw & ARS2 & 411240.49 & 1045114.96 & $22 \mathrm{ft} \mathrm{NE} \mathrm{ARS1}$ & 09/17/1998 \\
\hline Cheyenne & 6 & Childs Draw & ARS3 & 411240.49 & 1045114.96 & $40 \mathrm{ft}$ NE of ARS2 & 09/18/1998 \\
\hline Cheyenne & 7 & Dry Creek & BR1 & 411036.94 & 1044735.70 & N/A & $09 / 22 / 1998$ \\
\hline Cheyenne & 8 & Dry Creek & BR2 & 411036.94 & 1044735.70 & $30 \mathrm{ft}$ NW of BR1 & 09/23/1998 \\
\hline Cheyenne & 9 & Dry Creek & BR3 & 411036.94 & 1044735.70 & $50 \mathrm{ft} \mathrm{NE}$ of BR1 & $09 / 23 / 1998$ \\
\hline Cheyenne & 10 & Dry Creek & AFB1 & 411113.94 & 1045104.16 & N/A & 09/24/1998 \\
\hline Cheyenne & 11 & Dry Creek & AFB2 & 411113.94 & 1045104.16 & $\sim 25 \mathrm{ft} \mathrm{SW}$ of $\mathrm{AFB} 1$ & 09/24/1998 \\
\hline Casper & 12 & Garden Creek & $\mathrm{GC} 1$ & 424735 & 1062036 & N/A & 09/15/1999 \\
\hline Casper & 13 & Garden Creek & $\mathrm{GC} 2$ & 424735 & 1062036 & $20 \mathrm{ft} \mathrm{N}$ of $\mathrm{GC} 1$ & 09/16/1999 \\
\hline Casper & 14 & Garden Creek & GC3 & 424735 & 1062036 & - & 09/16/1999 \\
\hline Sheridan & 15 & Little Goose Creek & LG1 & 443938 & 1065721 & N/A & 09/20/1999 \\
\hline Sheridan & 16 & Little Goose Creek & LG2 & 443938 & 1065721 & 20-25 ft SE of LG1 & 09/20/1999 \\
\hline Sheridan & 17 & Little Goose Creek & LG3 & 443621 & 1070215 & - & 09/21/1999 \\
\hline Sheridan & 18 & Little Goose Creek & LG4 & 443621 & 1070215 & - & 09/21/1999 \\
\hline Gillette & 19 & Donkey Creek & DC1 & 441543 & 1053043 & N/A & 09/29/1999 \\
\hline Gillette & 20 & Donkey Creek & $\mathrm{DC} 2$ & 441543 & 1053043 & $50 \mathrm{ft} \mathrm{N}$ of $\mathrm{DC} 1$ & 09/29/1999 \\
\hline Gillette & 21 & Stonepile Creek & SP1 & 441746 & 1053427 & Within $150 \mathrm{ft}$ of creek & 09/29/1999 \\
\hline Gillette & 22 & Stonepile Creek & $\mathrm{SP} 2$ & 441746 & 1053427 & $25 \mathrm{ft}$ streamward of SP1 & 09/29/1999 \\
\hline Gillette & 23 & Stonepile Creek & SP3 & 441746 & 1053427 & $25 \mathrm{ft}$ shoreward of SP1 & 09/29/1999 \\
\hline
\end{tabular}


equivalent to AMC I can be assumed. An equivalent soil moisture condition between AMC II and AMC III can be assumed for BR1 because of light rain and cool temperatures for the 2 days prior to the test and the day of the test.

The equipment and procedures used to collect the infiltration data were in accordance with American Society for Testing and Materials (ASTM) guidance. The WYDOT specified that the infiltration data was to be collected using a ring infiltrometer. Although generally accepted, problems are associated with ring infiltrometers relative to collecting representative infiltration data. Some modifications to equipment design and data-collection procedures were made for this study with the intent of addressing these problems. These modifications are described, and supporting references are noted in the following paragraphs.

To promote vertical infiltration (that is, to mitigate the effects of lateral divergence), a double-ring infiltrometer design was used (American Society for Testing and Materials, 1994). The design was modified by increasing the inner-ring diameter from the commonly cited 12 in. $(\sim 30 \mathrm{~cm})$ to $\sim 24$ in. $(\sim 45 \mathrm{~cm})$; the outer-ring diameter was increased accordingly. Larger diameter rings minimize lateral infiltration (Klute, 1986). For reference, the effective ring diameter of the previously noted investigations by McQueen (1963), Rankl (1990), and Abdel-Magid and others (1987) were 6.18 in. $(15.7 \mathrm{~cm})$, 5.75 in. $(14.6 \mathrm{~cm})$, and 11.8 in. $(30.0 \mathrm{~cm})$ respectively. Speci-

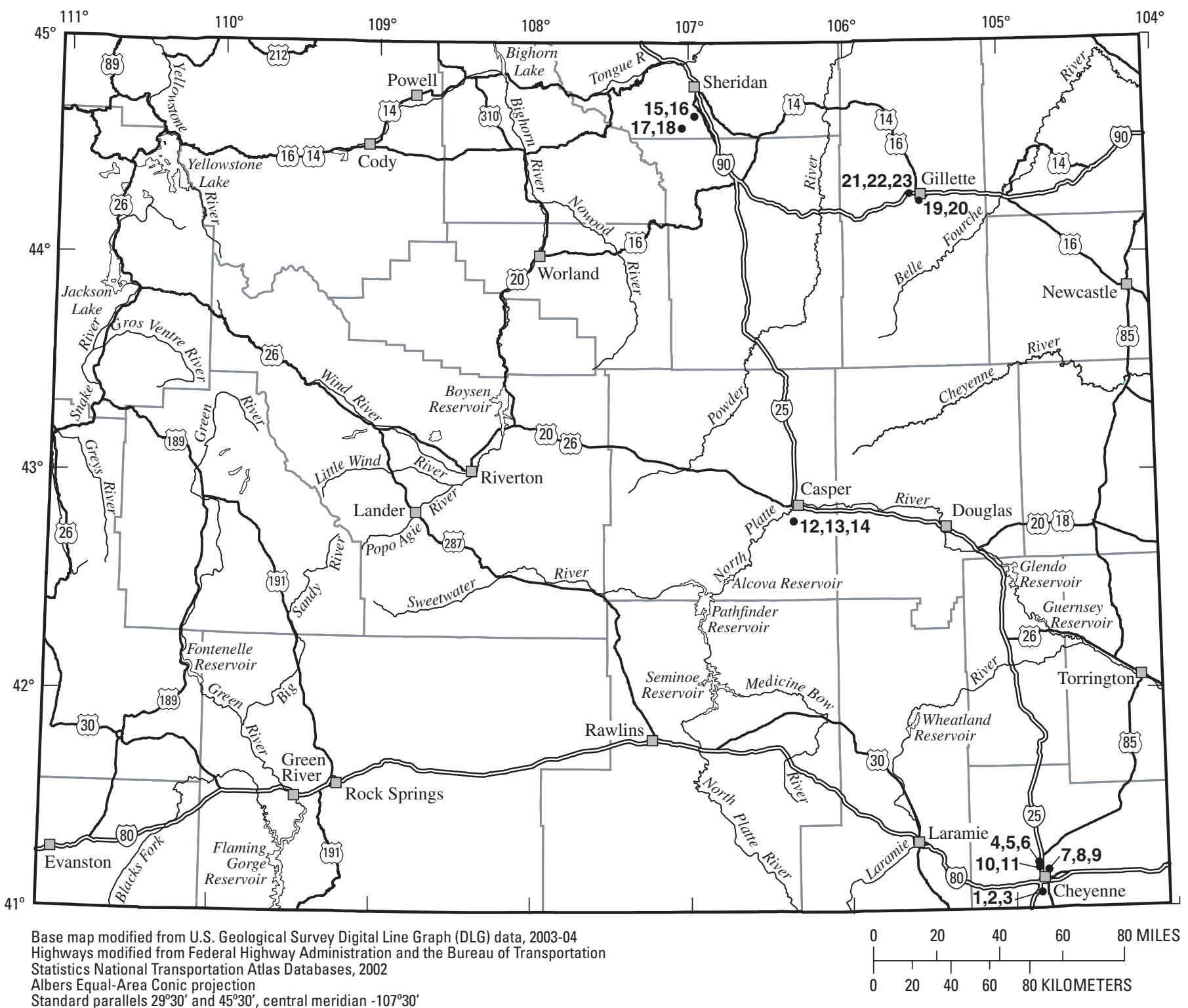

EXPLANATION

$\bullet^{1,2,3}$ Infiltration test sites and numbers

Figure 1. Location of infiltration test sites, Wyoming, 1998-99. 
fications for the rings are shown in figure 2. The exact area of the inner ring after construction was $458.0 \mathrm{in}^{2}\left(2,955 \mathrm{~cm}^{2}\right)$.

Table 2. Description of infiltration test site soil and vegetation properties.

[Soil name and hydrologic soils group(s) from U.S. Department of Agriculture (1997, 1998, 2005a, 2005b); do., ditto (indicates that the entry above it is repeated); --, no data.]

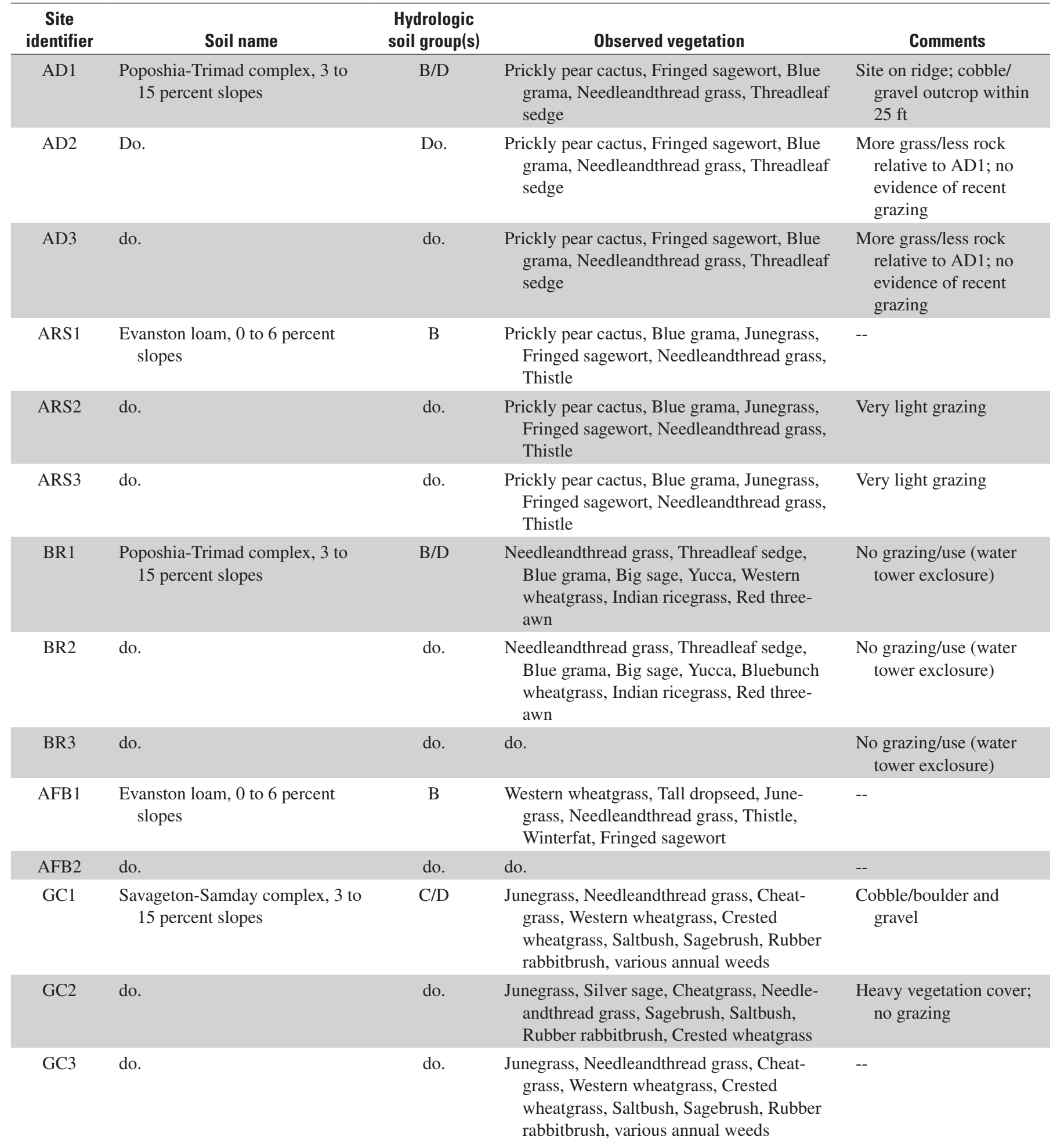


Table 2. Description of infiltration test site soil and vegetation properties.-Continued

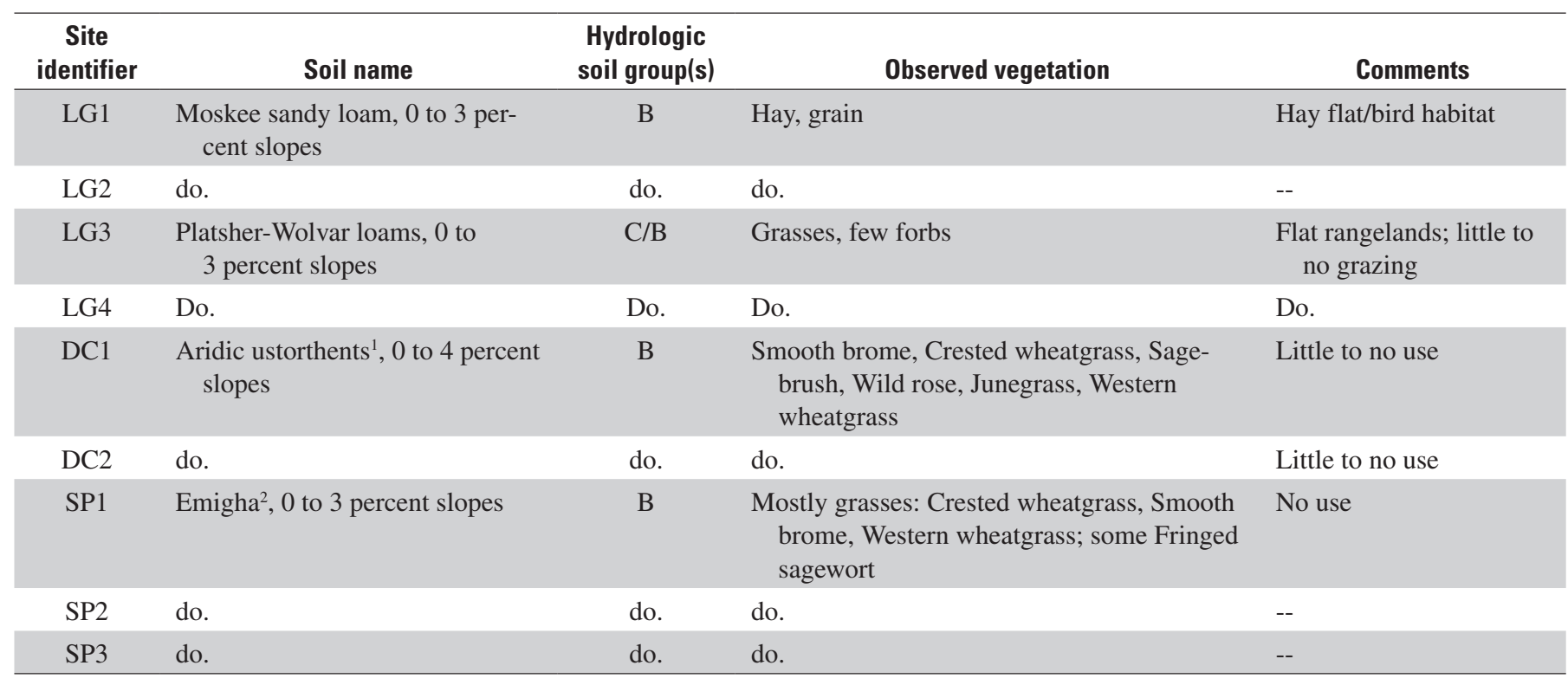

1) Taxon above Family.

2) Series.

Table 3. Description of Natural Resources Conservation Service's hydrologic soil groups.

[Source: U.S. Department of Agriculture (1995).]

\begin{tabular}{cl}
\hline $\begin{array}{c}\text { Hydrologic } \\
\text { soil group }\end{array}$ & Description \\
\hline A & High infiltration rates. Soils are deep, well drained to excessively drained sands and gravels. \\
B & $\begin{array}{c}\text { Moderate infiltration rates. Deep and moderately deep, moderately well and well drained soils with moderately coarse } \\
\text { textures. }\end{array}$ \\
C & $\begin{array}{c}\text { Slow infiltration rates. Soils with layers impeding downward movement of water, or soils with moderately fine or fine } \\
\text { textures. }\end{array}$ \\
D & Very slow infiltration rates. Soils are clayey, have a high water table, or are shallow to an impervious layer. \\
\hline
\end{tabular}

Table 4. Description of Natural Resources Conservation Service's antecedent soil moisture conditions.

[Source: Novotny and Olem (1994).]

\begin{tabular}{cl}
\hline $\begin{array}{c}\text { Antecedent soil } \\
\text { moisture (AMC) } \\
\text { condition }\end{array}$ & $\begin{array}{c}\text { A condition of watershed soils where the soils are dry but not to the wilting point, and when satisfactory plowing or } \\
\text { cultivation takes place. }\end{array}$ \\
\hline AMC I & $\begin{array}{c}\text { The average case for annual floods, that is, an average of the conditions that have preceded the occurrence of the } \\
\text { annual flood on numerous watersheds. } \\
\text { AMC II } \\
\text { AMC III } \\
\text { If heavy rainfall or light rainfall and low temperatures have occurred during the } 5 \text { days prior to the given storm and } \\
\text { the soil is nearly saturated. }\end{array}$ \\
\hline
\end{tabular}


For each test, the rings were driven into the soil a minimum of 2 in. $(5 \mathrm{~cm})$ (Klute, 1986) and a maximum of 6 in. $(15 \mathrm{~cm})$ (American Society for Testing and Materials, 1994; Johnson, 1963). Deeper penetration may result in increased soil disturbance (Klute, 1986). The rings were driven into the soil using the driving cap (fig. 2). A large timber was laid across the cap and struck with a sledge hammer. The timber was moved around the cap to facilitate driving the rings into the soil vertically. Alternatively, the rings were jacked into the soil using a vehicle and a high-lift jack. Even though the jacking method is preferred (American Society for Testing and Materials, 1994), it was not always possible for the conditions encountered during this study.

Water for the infiltration tests was supplied by two containers (fig. 3). A 50-L polyethylene carboy was used to supply water to the inner ring. Water for the outer ring was supplied by a separate, larger non-metallic container. Sources for the water in each container were local municipal supplies. A graduated sight tube was attached to the side of the 50-L carboy and calibrated by averaging multiple $250-\mathrm{mL}$ withdrawals. To begin the infiltration test, the initial site tube reading and the time were noted and both rings were filled quickly to some arbitrary shallow depth generally between 2 to 3 in. (5 to $8 \mathrm{~cm})$. Larger depths may result in higher infiltration rates (Klute, 1986). The test proceeded by maintaining this constant depth (head). For the inner ring, a float valve fixed to the side of the ring automatically maintained the constant head. For the outer ring, the constant head was maintained manually by periodically measuring the depth and adding more water as needed. Site tube readings were made periodically; initially, readings were noted every few minutes. The test continued until a base infiltration rate (Trout and others, 1982) was attained or until the inner ring water supply was exhausted.

\section{Description of Infiltration Tests}

Infiltration tests were completed on seven soils/soil complexes on slopes ranging from 0 to 15 percent. Hydrologic soil groups at these test sites ranged from B (moderate infiltration) to $\mathrm{C} / \mathrm{D}$ (slow to very slow infiltration). Vegetation cover was typical of grasslands and rangelands of the High Plains and Powder River Basin, Wyoming. Incremental infiltration rates were calculated and plotted according to published guidelines (American Society for Testing and Materials, 1994) (Appendixes 1 and 2.). To facilitate comparison, the graphs were scaled the same for all tests. It should be noted that a few tests exceeded 3 hours elapsed time; although these data do not appear on the graphs, they are included in the tables.

Eleven tests were completed in three watersheds near Cheyenne during September 15-24, 1998. Three tests were completed in Allison Draw on an upland plateau southwest of Cheyenne (AD1, AD2, and AD3). Nearby outcrops of cobble and gravel were noted. All three tests were run past an appar- ent base infiltration rate. Three more tests were completed in Childs Draw on the USDA High Plains Grasslands Research Station north of Cheyenne (ARS1, ARS2, and ARS3). All three tests had not reached an apparent base infiltration prior to exhausting the water supply. The water supply to the inner ring was interrupted at about 2.8 hours elapsed time for test ARS3; after adjusting the supply hose, flow was restored and the test continued. Three more tests were completed on the Dry Creek side of Buffalo Ridge in the northern part of Cheyenne (BR1, BR2, and BR3). The test sites were within the water tower exclosure. All three tests were run past an apparent base infiltration rate. Light rain and cool temperatures occurred 2 days prior to and during the day of test BR1. Infiltration data from tests BR2 and BR3 compare well with each other. Another two tests were completed for the Dry Creek watershed near the eastern edge of F.E. Warren Air Force Base (AFB1 and AFB2). Both tests had not reached an apparent base infiltration prior to exhausting the water supply. The water supply to the inner ring was interrupted at about 1.5 hours elapsed time for test ARS2; after adjusting the supply hose, flow was restored and the test continued.

Three tests were completed in the Garden Creek watershed near Casper during September 15 and 16, 1999. Test sites GC1, GC2, and GC3 were located east of Garden Creek Road about 1 mile north of Wyoming Boulevard. An apparent base infiltration rate was not reached prior to ending any of the tests. A leak at the soil-ring interface developed during test $\mathrm{GC} 1$; data from this test are considered suspect.

Four tests were completed at two locations in the Little Goose Creek watershed near Sheridan during September 20 and 21, 1999. Test sites LG1 and LG2 were located on a Wyoming Game and Fish Department Bird Farm hay flat. Test sites LG3 and LG4 were located in a county road right-of-way near the Little Goose Ranch, about 6 miles south of Big Horn. Apparent base infiltration rates were approached near the end of all four tests.

Five tests were completed in two watersheds near Gillette on September 29, 1999. Tests DC1 and DC2 were located within $50 \mathrm{ft}$ of Donkey Creek on Gillette High School property south of Gillette. Problems with the float valve near the end of both tests increased the inner-ring water levels. Infiltration data from the tests compare well with each other. Tests SP1, SP2, and SP3 were located within $150 \mathrm{ft}$ of Stonepile Creek, about 2 miles east of Gillette. Problems with the float valve near the end of test SP2 increased inner-ring water levels. Apparent base infiltration rates were not reached prior to the end of any of the tests. 


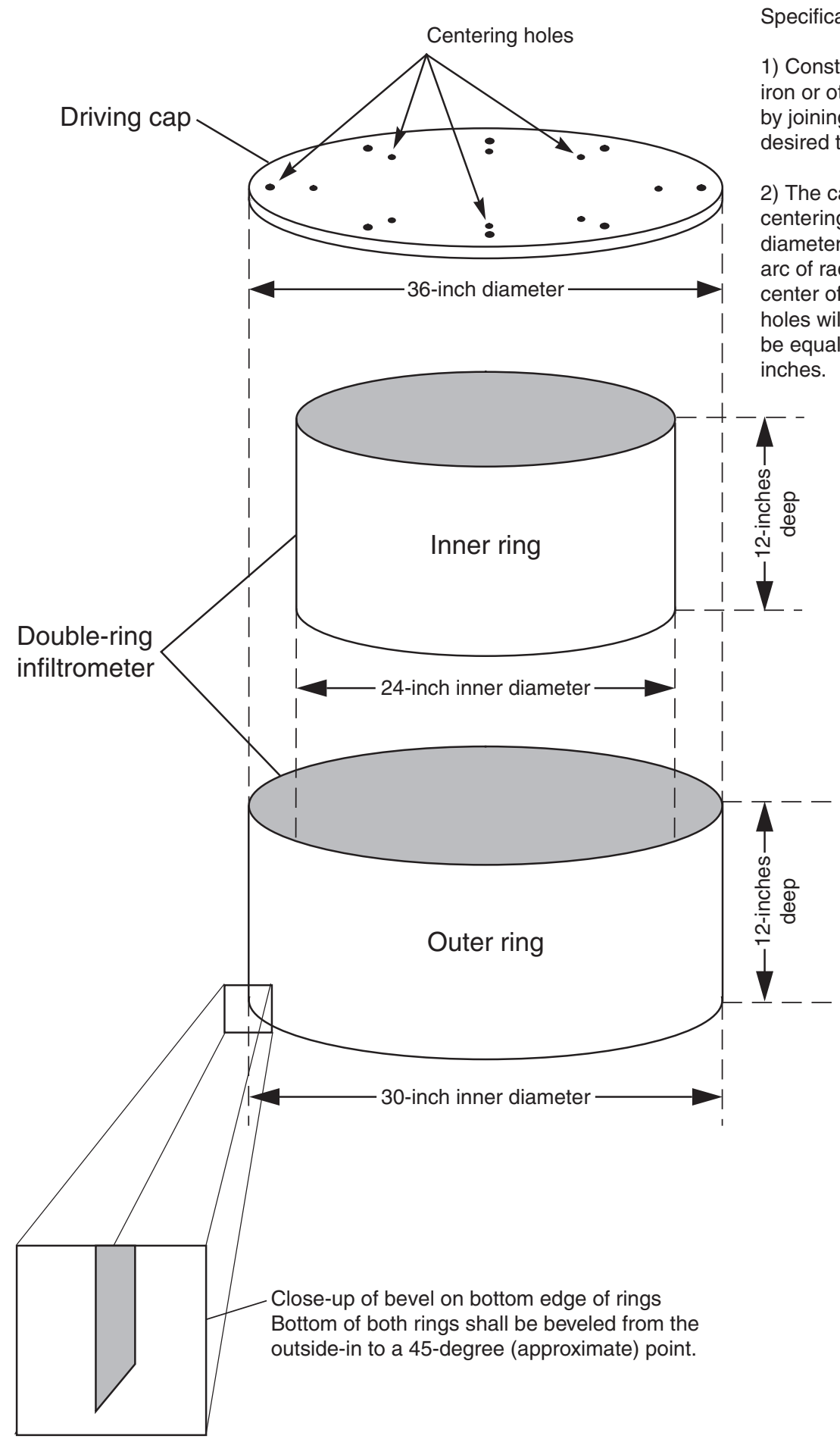

Specifications for rings:

1) Constructed of 1/8-inch (approximate) thick black iron or other heavy metal so as to withstand repeated driving into ground with a $1 / 2-\mathrm{lb}$ sledge hammer.

2) Rings shall be riveted or welded at the joint so as to withstand repeated use; joint shall be water tight.

Figure 2. Schematic diagram and construction specifications for double-ring infiltrometer. 


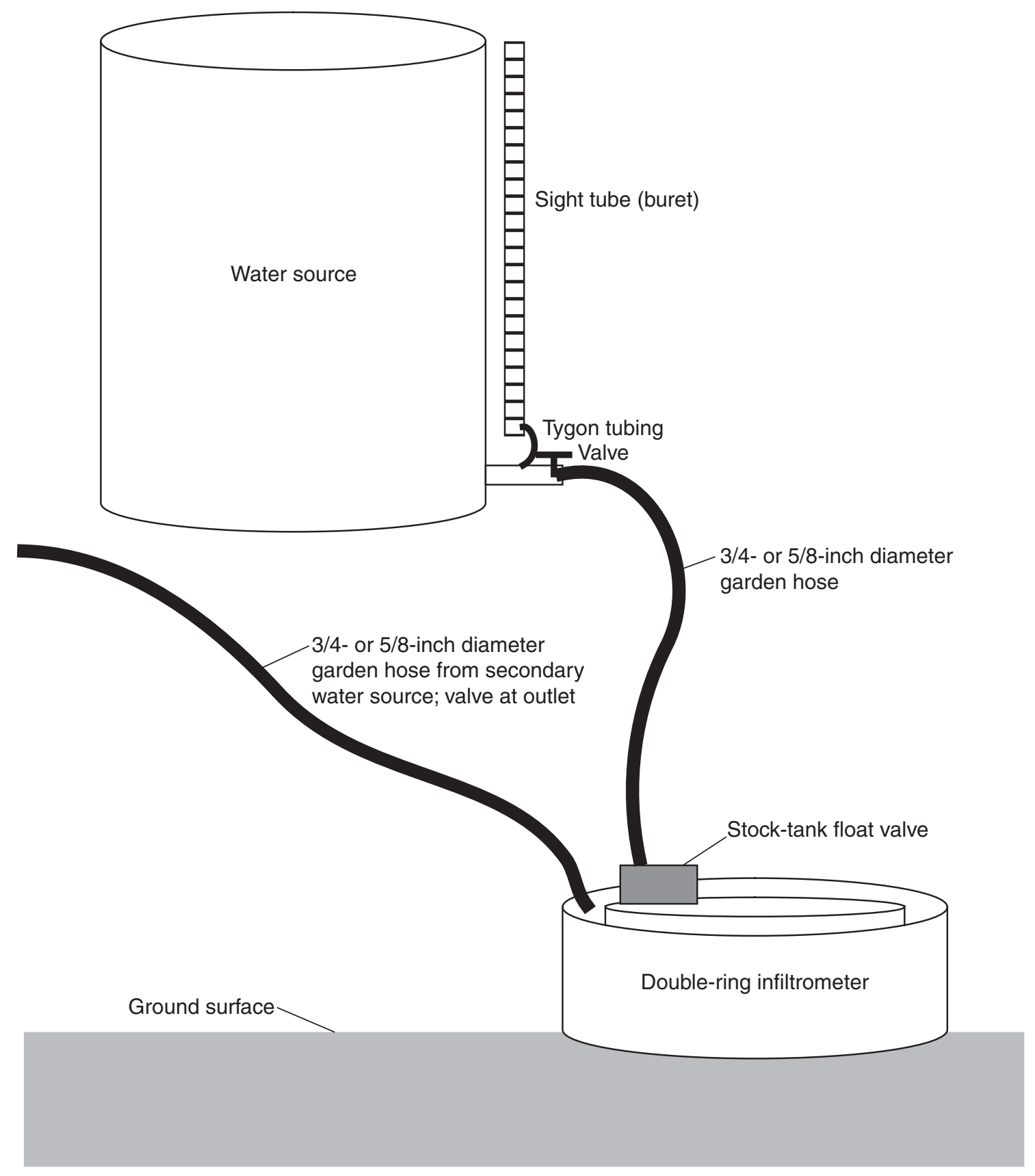

Figure 3. Schematic of infiltration measurement equipment. 


\section{References}

Abdel-Magid, A.H., Schuman, G.E., and Hart, R.H., 1987, Soil bulk density and water infiltration as affected by grazing systems: Journal of Range Management, v. 40, no. 4, p. 307-309.

American Society for Testing and Materials, 1994, Standard test method for infiltration rate of soils in field using double-ring infiltrometer: ASTM 3385-94, 7 p.

Frasier, G.W., Hart, R.H., and Schuman, G.E., 1995, Impact of grazing intensity on infiltration/runoff characteristics of a shortgrass prairie: Fifth International Rangeland Congress 1995, p. 159-160.

Johnson, A.I., 1963, A field method of measurement of infiltration: U.S. Geological Survey Water-Supply Paper 1544-F, p. 4-9.

Klute, Arnold, ed., 1986, Methods of soil analysis-part 1. Physical and mineralogical methods (2d edition): Madison, Wisc., American Society of Agronomy, Soil Science Society of America, $1188 \mathrm{p}$.

McQueen, I.S., 1963, Development of a hand portable rainfallsimulator infiltrometer: U.S. Geological Survey Circular $482,16 \mathrm{p}$.

Novotny, Vladimir, and Olem, Harvey, 1994, Water quality-Prevention, identification, and management of diffuse pollution: New York, Van Nostrand Reinhold, 1,054 p.

Rankl, J.G., 1990, A point-infiltration model for estimating runoff from rainfall on small basins in semiarid areas of Wyoming: U.S. Geological Survey Water-Supply Paper 2366, 29 p.
Trout, T.J., Garcia-Castillas, I.G., and Hart, W.E., 1982, Soilwater engineering - Field and laboratory manual: Department of Agricultural and Chemical Engineering, Colorado State University, 193 p.

U.S. Department of Agriculture, 1986, Urban hydrology for small watersheds (PDF version): U.S. Department of Agriculture, Natural Resources Conservation Service Technical Release 55 (TR-55), chapter 2.

U.S. Department of Agriculture, 1995, State soil geographic (STATSGO) data base-Data use information (PDF version): U.S. Department of Agriculture, Natural Resources Conservation Service Miscellaneous Publication Number $1492,113 \mathrm{p}$.

U.S. Department of Agriculture, 1997, Soil survey of Natrona County, Wyoming: U.S. Department of Agriculture, Soil Conservation Service, total number of pages unknown.

U.S. Department of Agriculture, 1998, Soil survey of Sheridan County area, Wyoming: U.S. Department of Agriculture, Natural Resources Conservation Service, 704 p.

U.S. Department of Agriculture, 2005a, Soil survey geographic (SSURGO) data base for Campbell County, Wyoming, southern part: U.S. Department of Agriculture, Natural Resources Conservation Service, Fort Worth, Texas, online version accessed 8/16/2005 at http://SoilDataMart. nrcs.usda.gov/.

U.S. Department of Agriculture, 2005b, Soil survey geographic (SSURGO) data base for Laramie County, Wyoming, western part: U.S. Department of Agriculture, Natural Resources Conservation Service, Fort Worth, Texas, online version accessed 8/16/2005 at http://SoilDataMart.nrcs. usda.gov/. 

Appendix 1. Graphs of Infiltration Data 


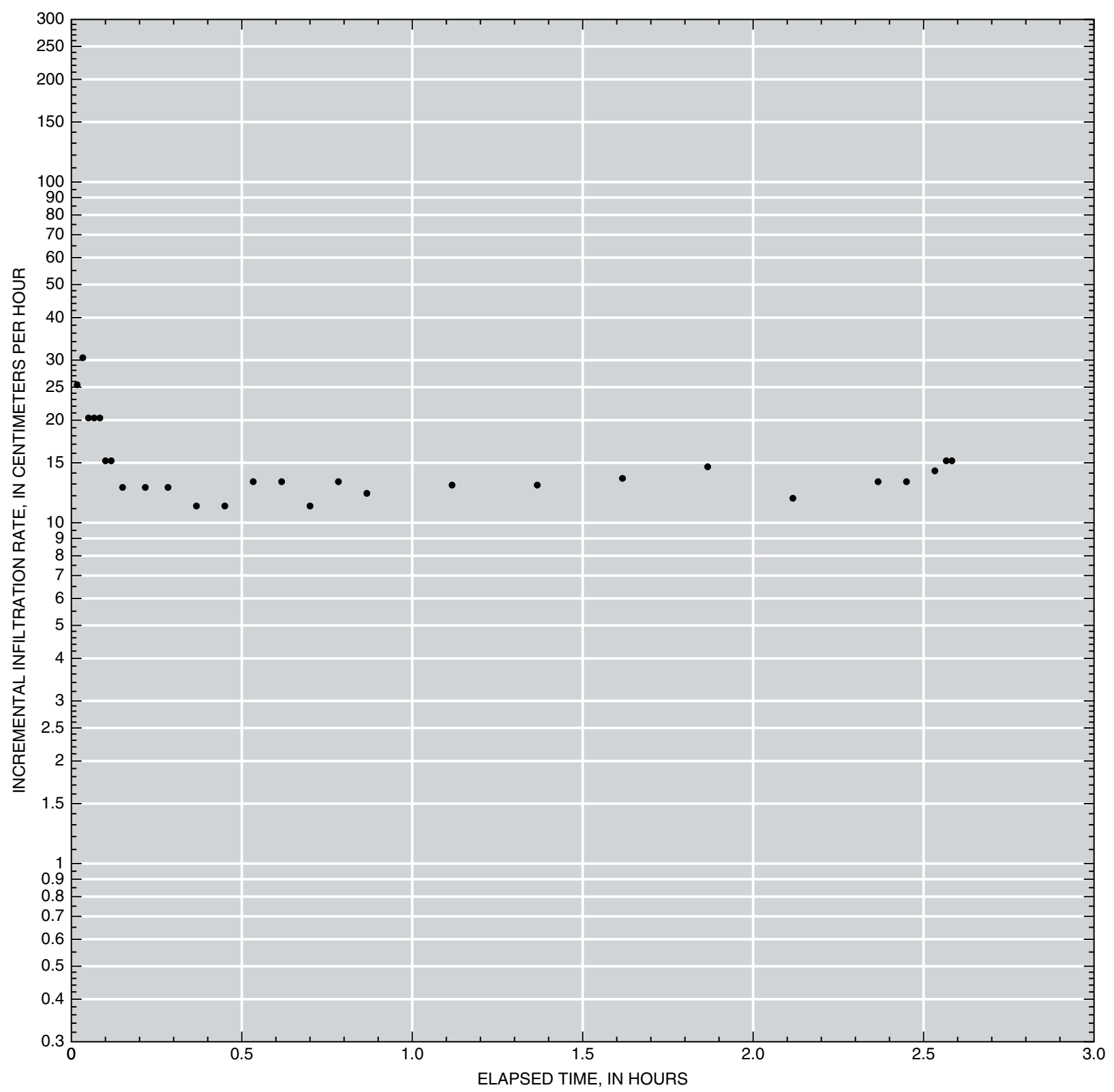

Incremental infiltration rate (velocity) is calculated as:

$\mathrm{v}=\mathrm{dV} /(\mathrm{A} * \mathrm{dt})$

where:

$\mathrm{v}=$ incremental infiltration velocity, in centimeters per hour,

$\mathrm{dV}=$ volume of water used during time interval to maintain constant head, in milliliters,

$A=$ area of ring infiltrometer, in square centimeters,

$d t=$ time interval, in hours.

Modified from American Society for Testing and Materials (1994)

Appendix 1-1. Infiltration data for site AD1. 


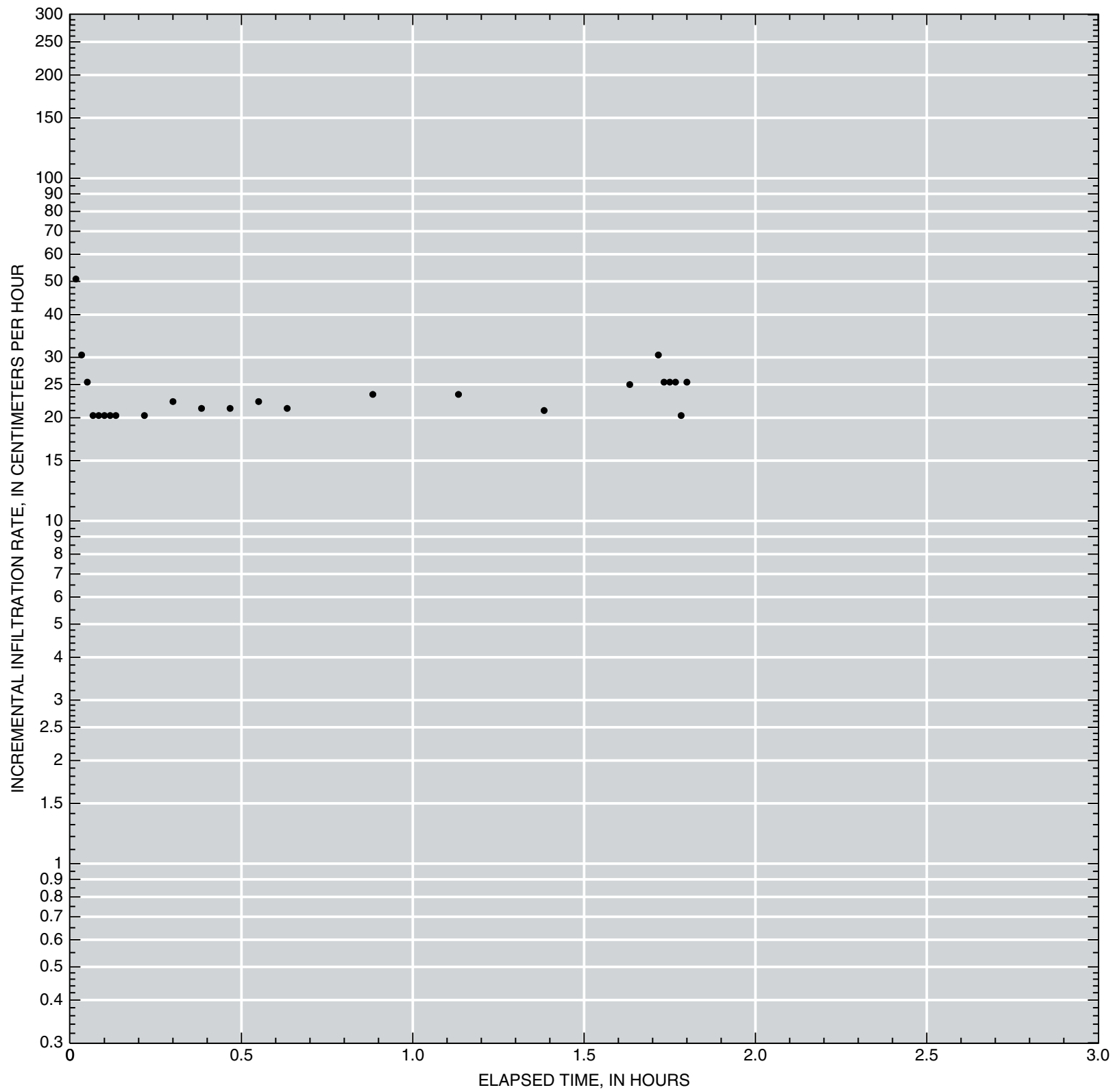

Incremental infiltration rate (velocity) is calculated as:

$\mathrm{V}=\mathrm{dV} /(\mathrm{A} * \mathrm{dt})$

where:

$\mathrm{v}=$ incremental infiltration velocity, in centimeters per hour,

$d V=$ volume of water used during time interval to maintain constant head, in milliliters,

$A=$ area of ring infiltrometer, in square centimeters,

$d t=$ time interval, in hours.

Modified from American Society for Testing and Materials (1994)

Appendix 1-2. Infiltration data for site AD2. 


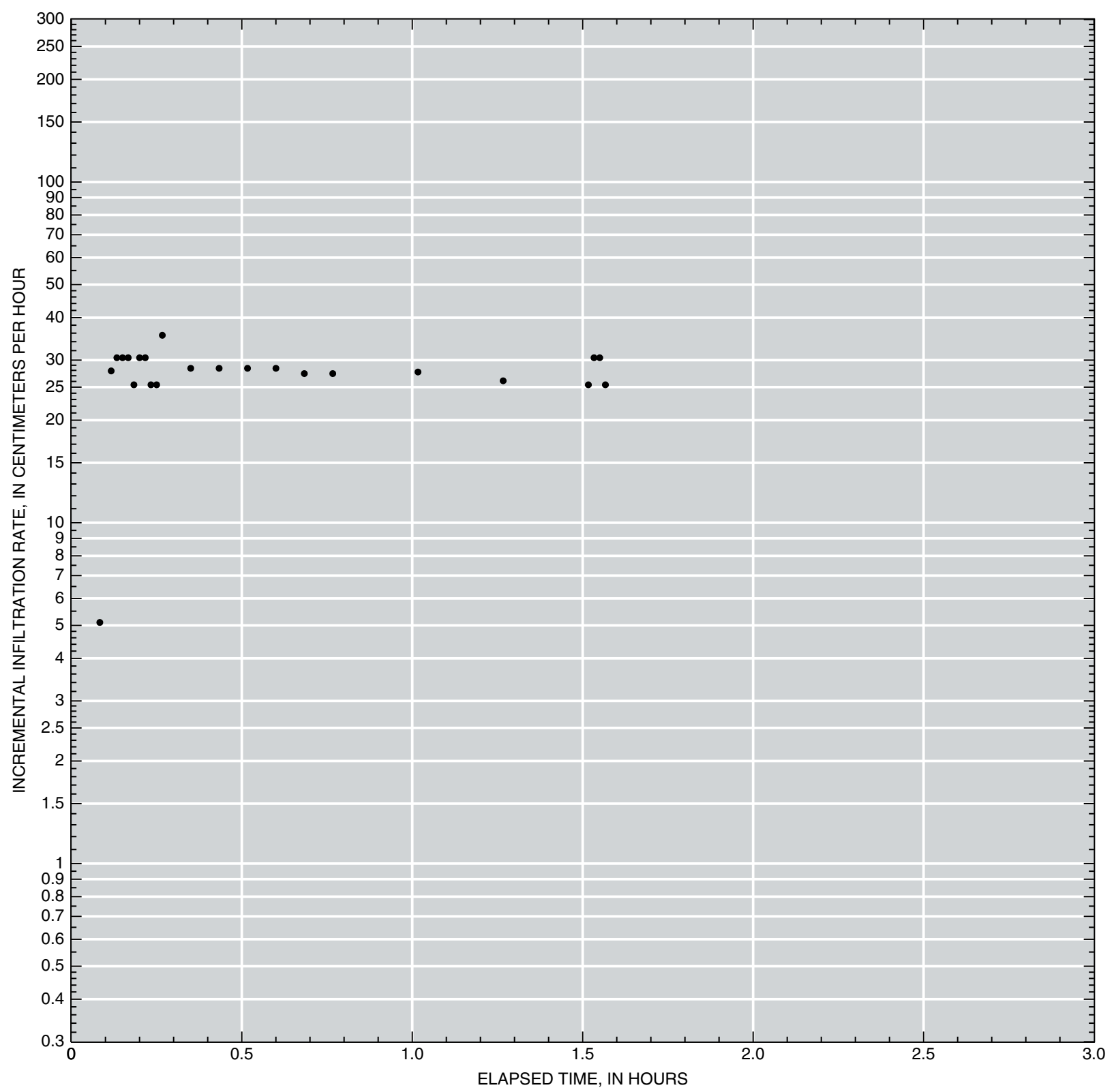

Incremental infiltration rate (velocity) is calculated as:

$\mathrm{v}=\mathrm{dV} /(\mathrm{A} * \mathrm{dt})$

where:

$\mathrm{v}=$ incremental infiltration velocity, in centimeters per hour,

$\mathrm{dV}=$ volume of water used during time interval to maintain constant head, in milliliters,

$A=$ area of ring infiltrometer, in square centimeters,

$d t=$ time interval, in hours.

Modified from American Society for Testing and Materials (1994)

Appendix 1-3. Infiltration data for site AD3. 


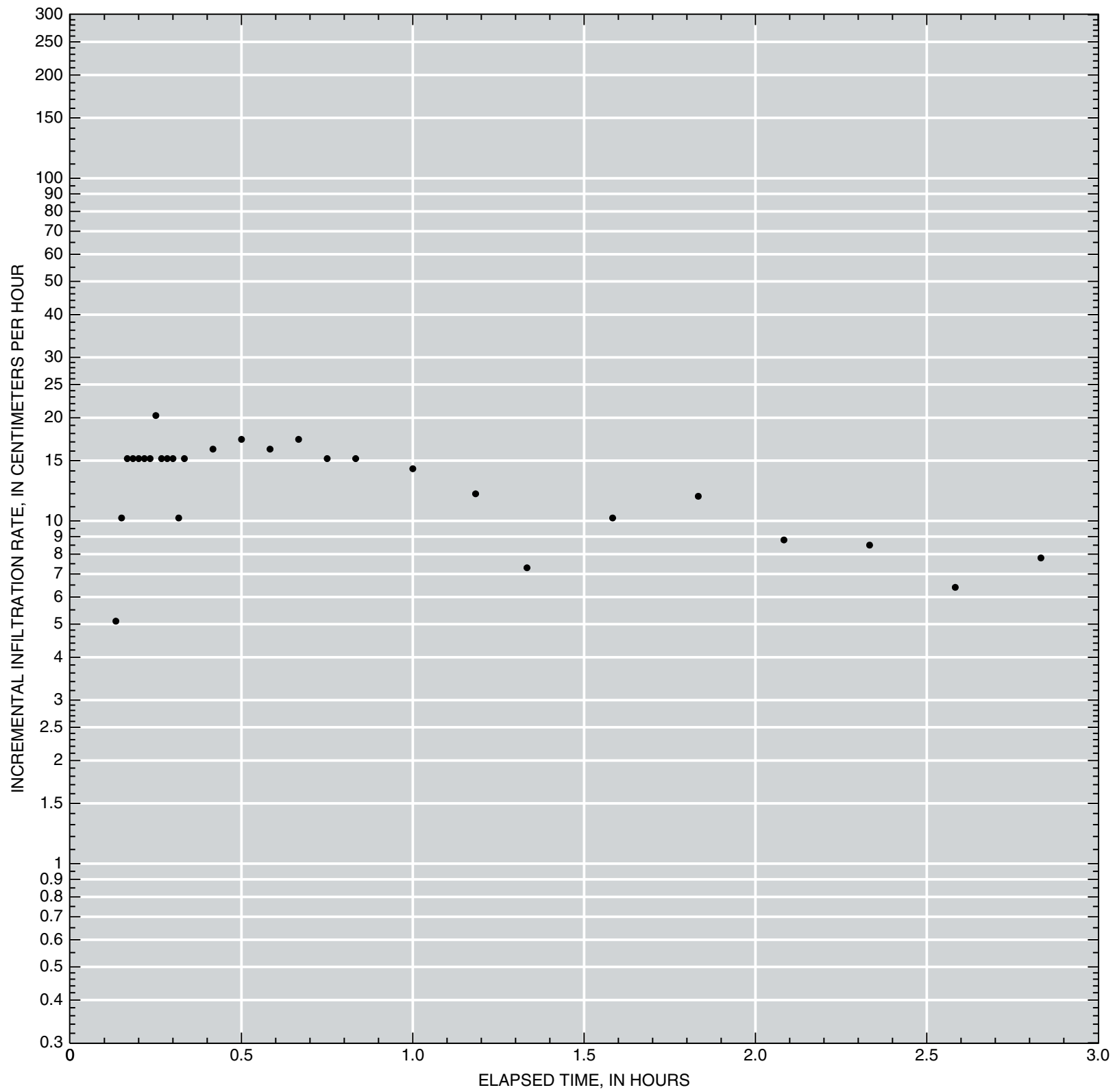

Incremental infiltration rate (velocity) is calculated as:

$\mathrm{V}=\mathrm{dV} /(\mathrm{A} * \mathrm{dt})$

where:

$\mathrm{v}=$ incremental infiltration velocity, in centimeters per hour,

$\mathrm{dV}=$ volume of water used during time interval to maintain constant head, in milliliters,

$A=$ area of ring infiltrometer, in square centimeters,

$d t=$ time interval, in hours.

Modified from American Society for Testing and Materials (1994)

Appendix 1-4. Infiltration data for site ARS1. 


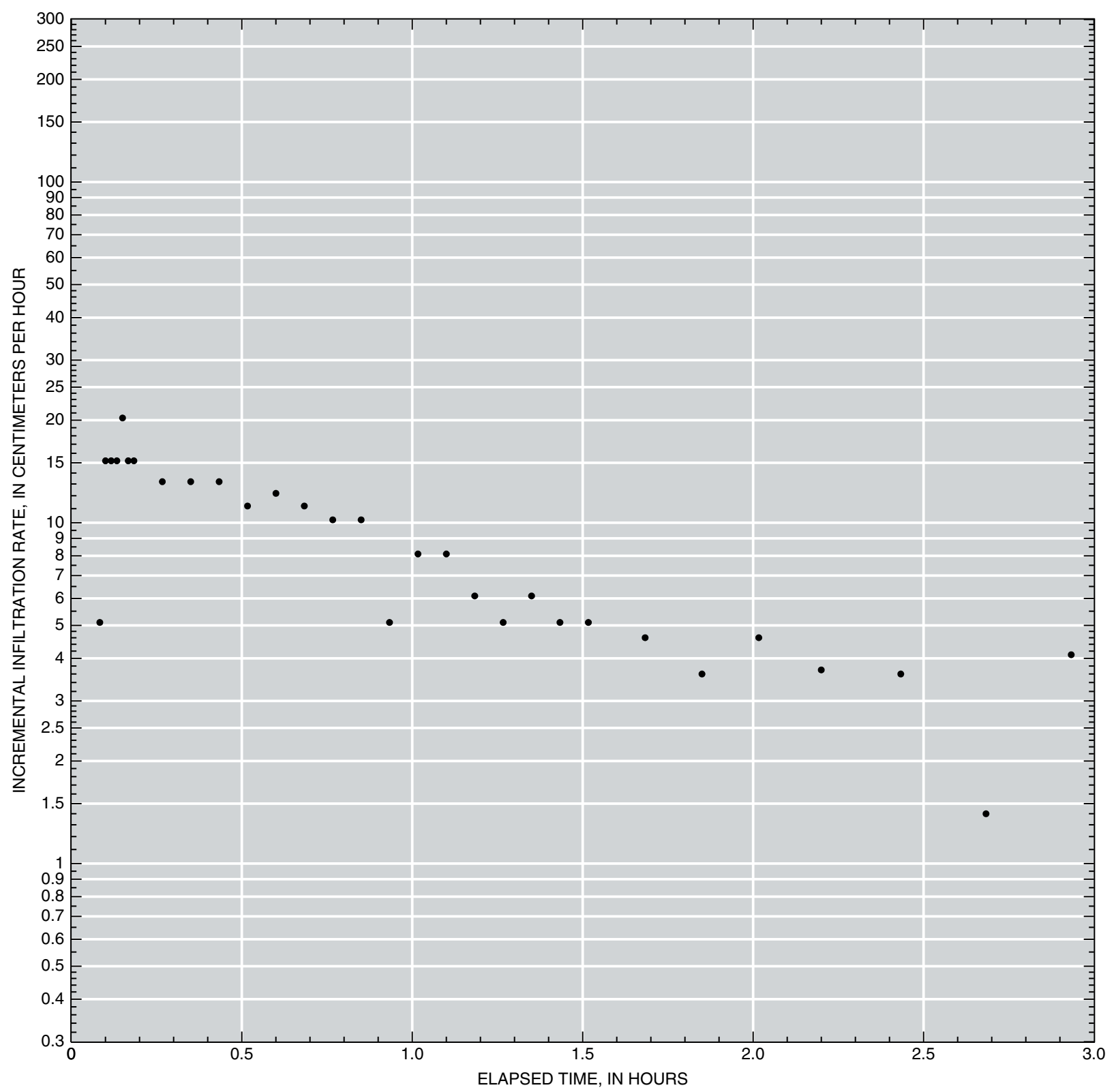

Incremental infiltration rate (velocity) is calculated as:

$\mathrm{v}=\mathrm{dV} /(\mathrm{A} * \mathrm{dt})$

where:

$\mathrm{v}=$ incremental infiltration velocity, in centimeters per hour,

$\mathrm{dV}=$ volume of water used during time interval to maintain constant head, in milliliters,

$A=$ area of ring infiltrometer, in square centimeters,

$d t=$ time interval, in hours.

Modified from American Society for Testing and Materials (1994)

Appendix 1-5. Infiltration data for site ARS2. 


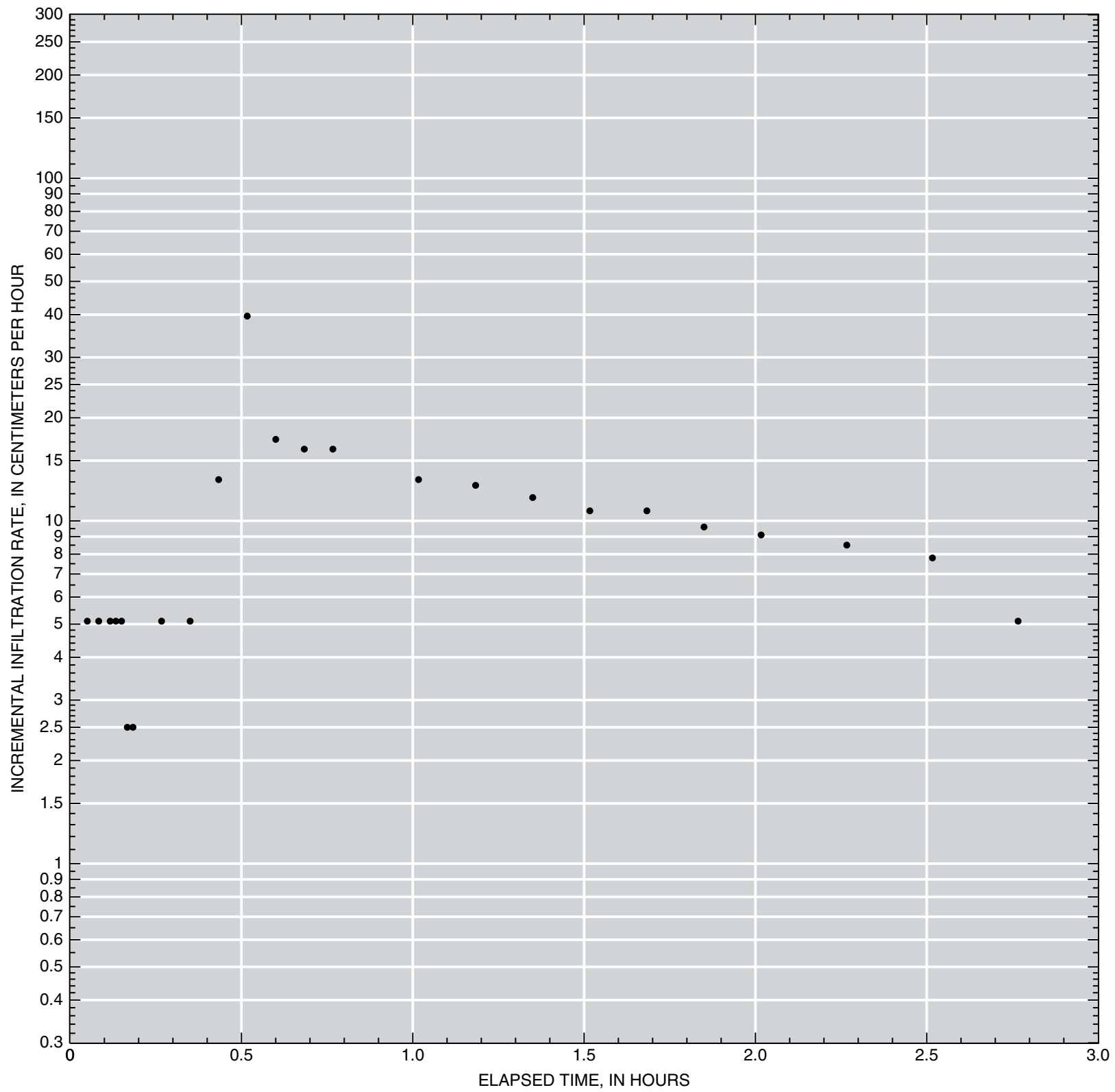

Incremental infiltration rate (velocity) is calculated as:

$\mathrm{V}=\mathrm{dV} /(\mathrm{A} * \mathrm{dt})$

where:

$\mathrm{v}=$ incremental infiltration velocity, in centimeters per hour,

$\mathrm{dV}=$ volume of water used during time interval to maintain constant head, in milliliters,

$A=$ area of ring infiltrometer, in square centimeters,

$d t=$ time interval, in hours.

Modified from American Society for Testing and Materials (1994)

Appendix 1-6. Infiltration data for site ARS3. 


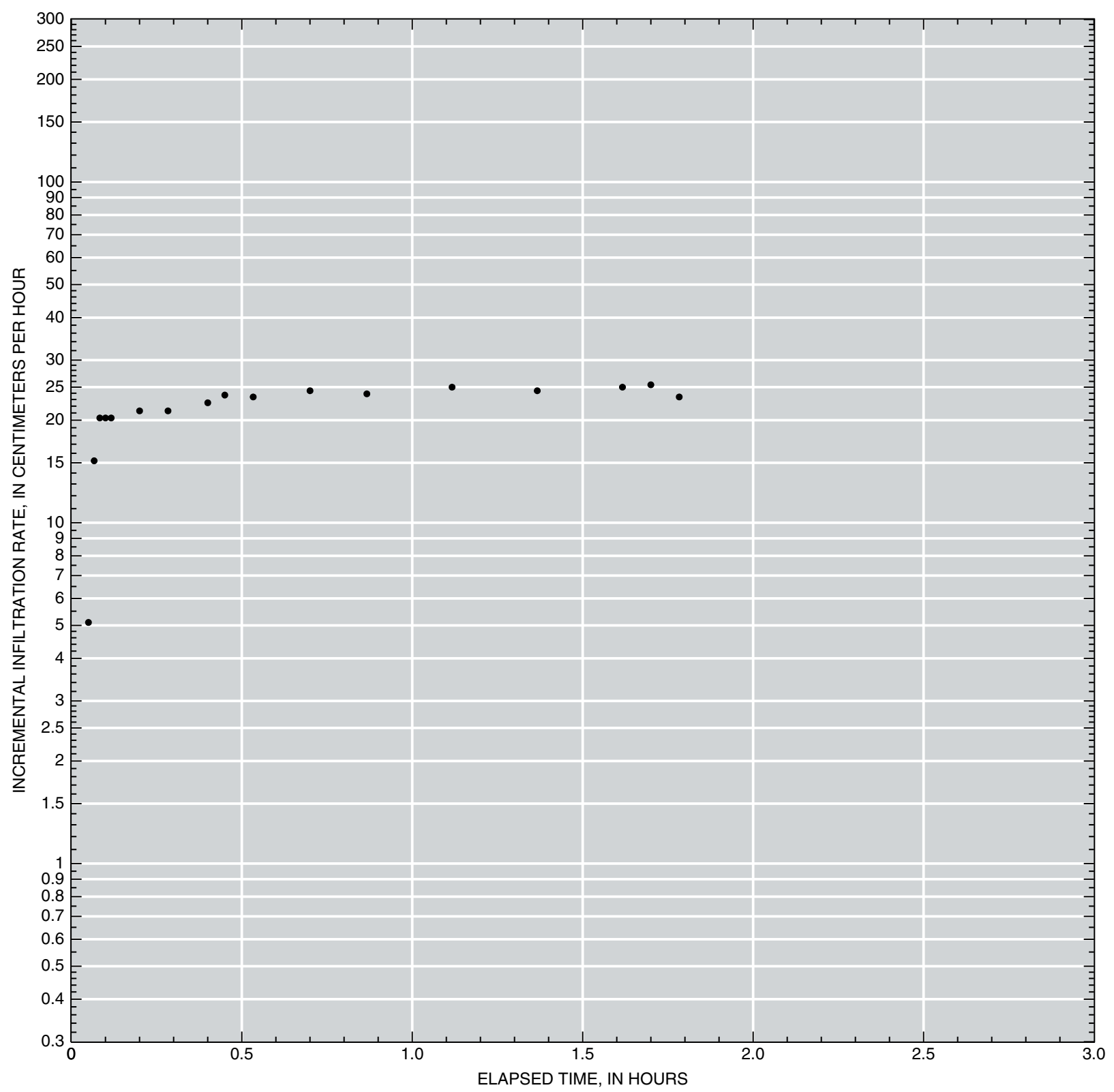

Incremental infiltration rate (velocity) is calculated as:

$\mathrm{v}=\mathrm{dV} /(\mathrm{A} * \mathrm{dt})$

where:

$\mathrm{v}=$ incremental infiltration velocity, in centimeters per hour,

$\mathrm{dV}=$ volume of water used during time interval to maintain constant head, in milliliters,

$A=$ area of ring infiltrometer, in square centimeters,

$d t=$ time interval, in hours.

Modified from American Society for Testing and Materials (1994)

Appendix 1-7. Infiltration data for site BR1. 


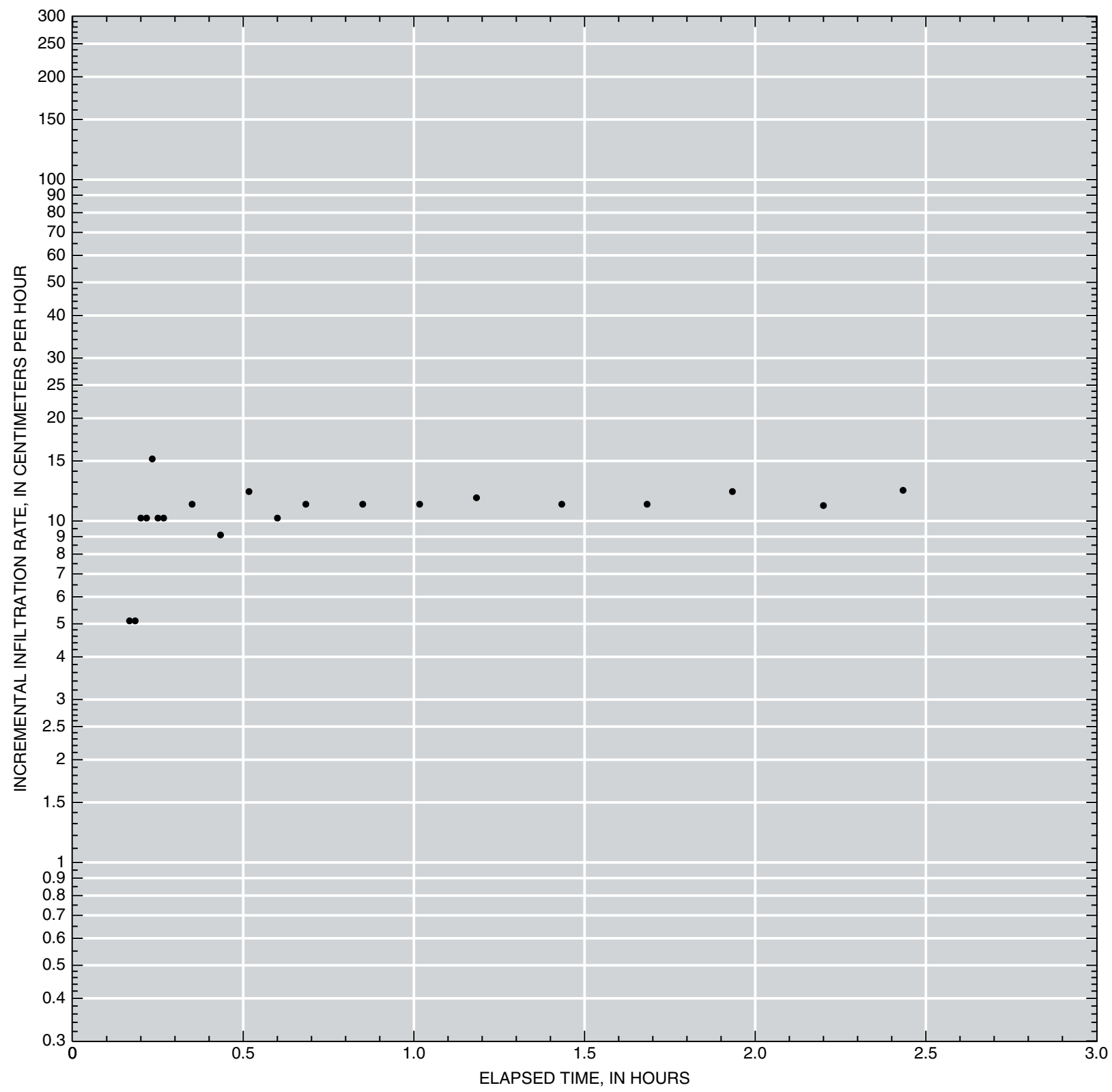

Incremental infiltration rate (velocity) is calculated as:

$\mathrm{V}=\mathrm{dV} /(\mathrm{A} * \mathrm{dt})$

where:

$\mathrm{v}=$ incremental infiltration velocity, in centimeters per hour,

$d V=$ volume of water used during time interval to maintain constant head, in milliliters,

$A=$ area of ring infiltrometer, in square centimeters,

$d t=$ time interval, in hours.

Modified from American Society for Testing and Materials (1994)

Appendix 1-8. Infiltration data for site BR2. 


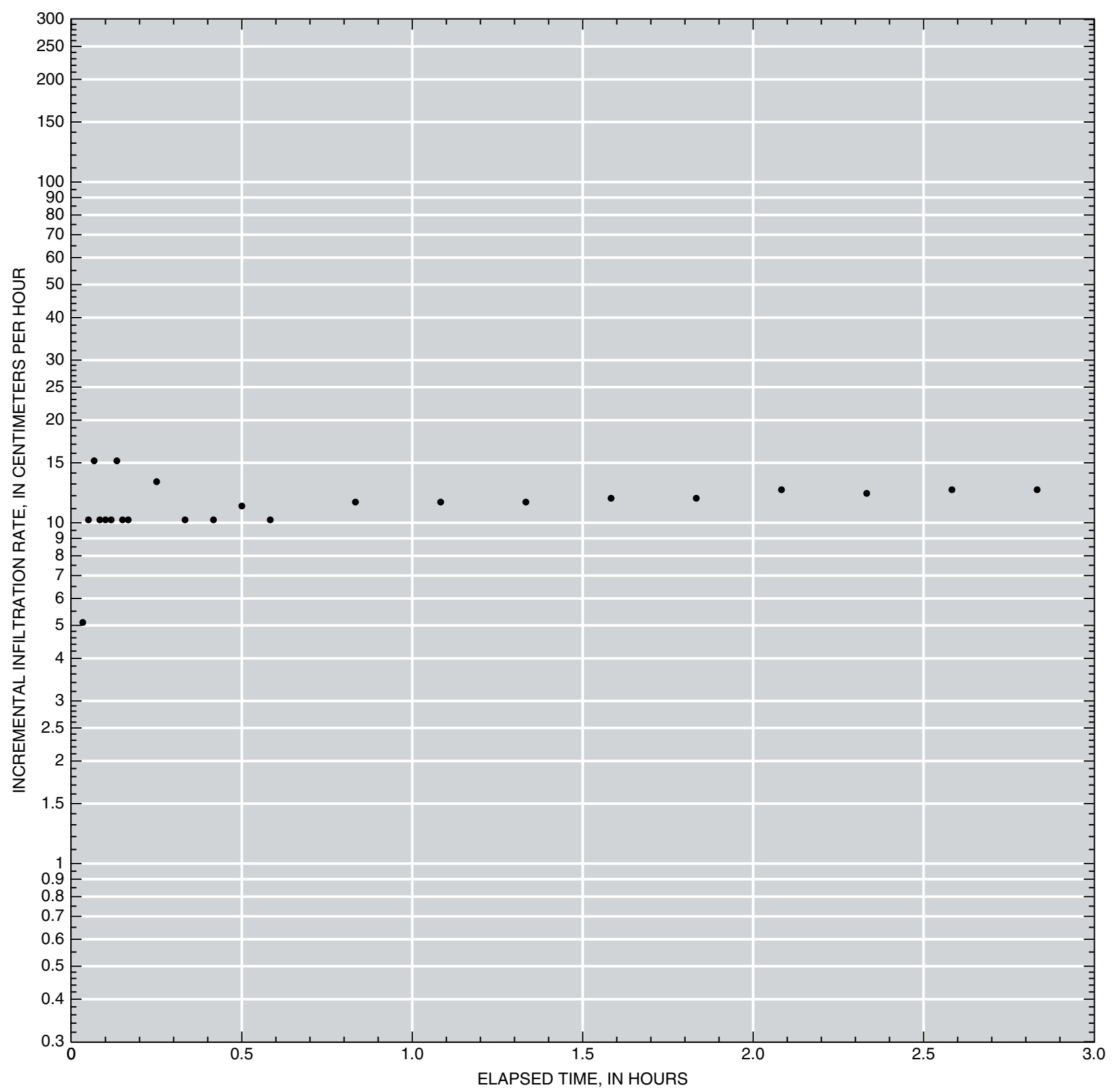

Incremental infiltration rate (velocity) is calculated as:

$\mathrm{v}=\mathrm{dV} /(\mathrm{A} * \mathrm{dt})$

where:

$\mathrm{v}=$ incremental infiltration velocity, in centimeters per hour,

$\mathrm{dV}=$ volume of water used during time interval to maintain constant head, in milliliters,

$A=$ area of ring infiltrometer, in square centimeters,

$d t=$ time interval, in hours.

Modified from American Society for Testing and Materials (1994)

Appendix 1-9. Infiltration data for site BR3. 


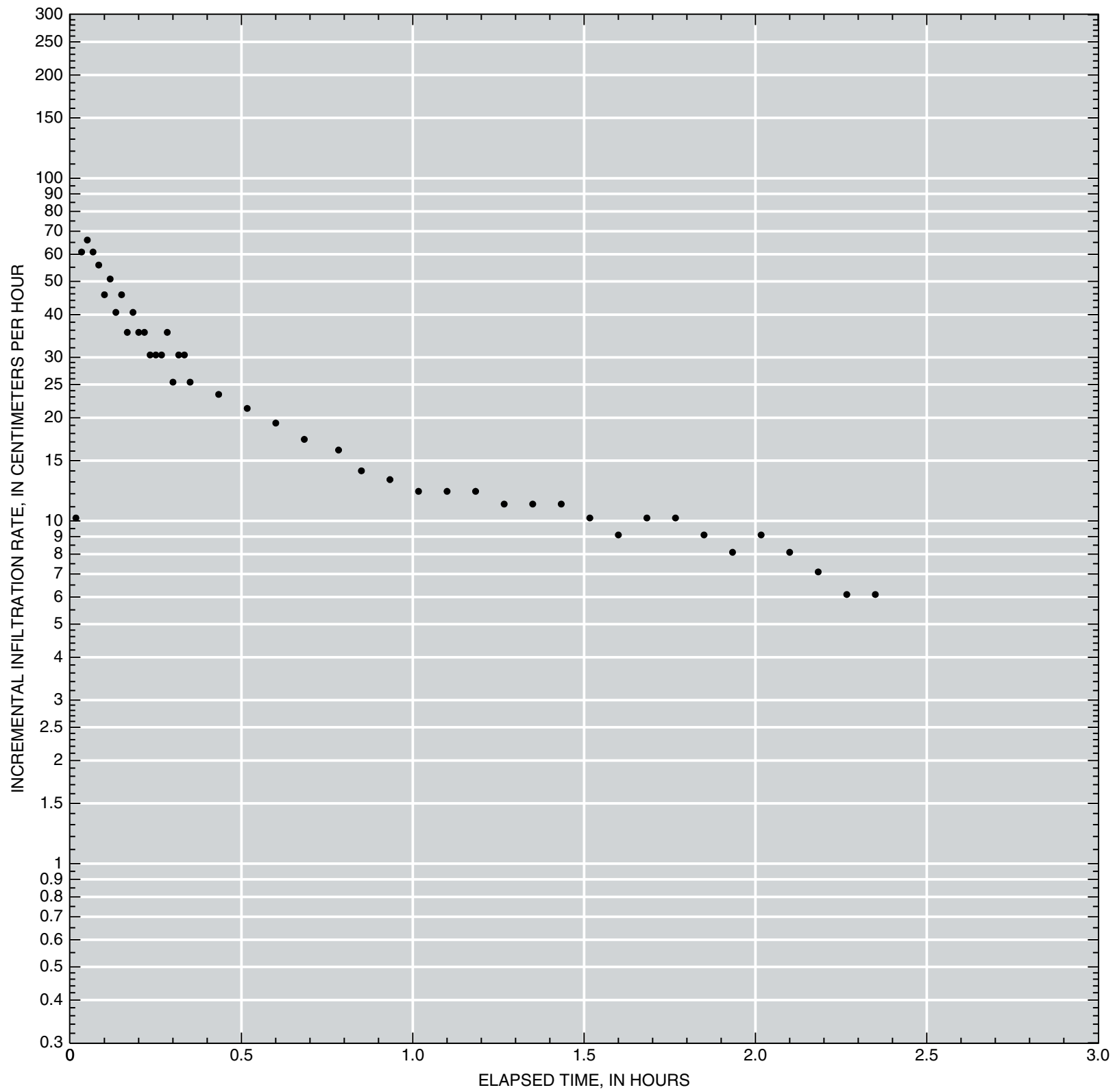

Incremental infiltration rate (velocity) is calculated as:

$\mathrm{V}=\mathrm{dV} /(\mathrm{A} * \mathrm{dt})$

where:

$\mathrm{v}=$ incremental infiltration velocity, in centimeters per hour,

$\mathrm{dV}=$ volume of water used during time interval to maintain constant head, in milliliters,

$A=$ area of ring infiltrometer, in square centimeters,

$d t=$ time interval, in hours.

Modified from American Society for Testing and Materials (1994)

Appendix 1-10. Infiltration data for site AFB1. 


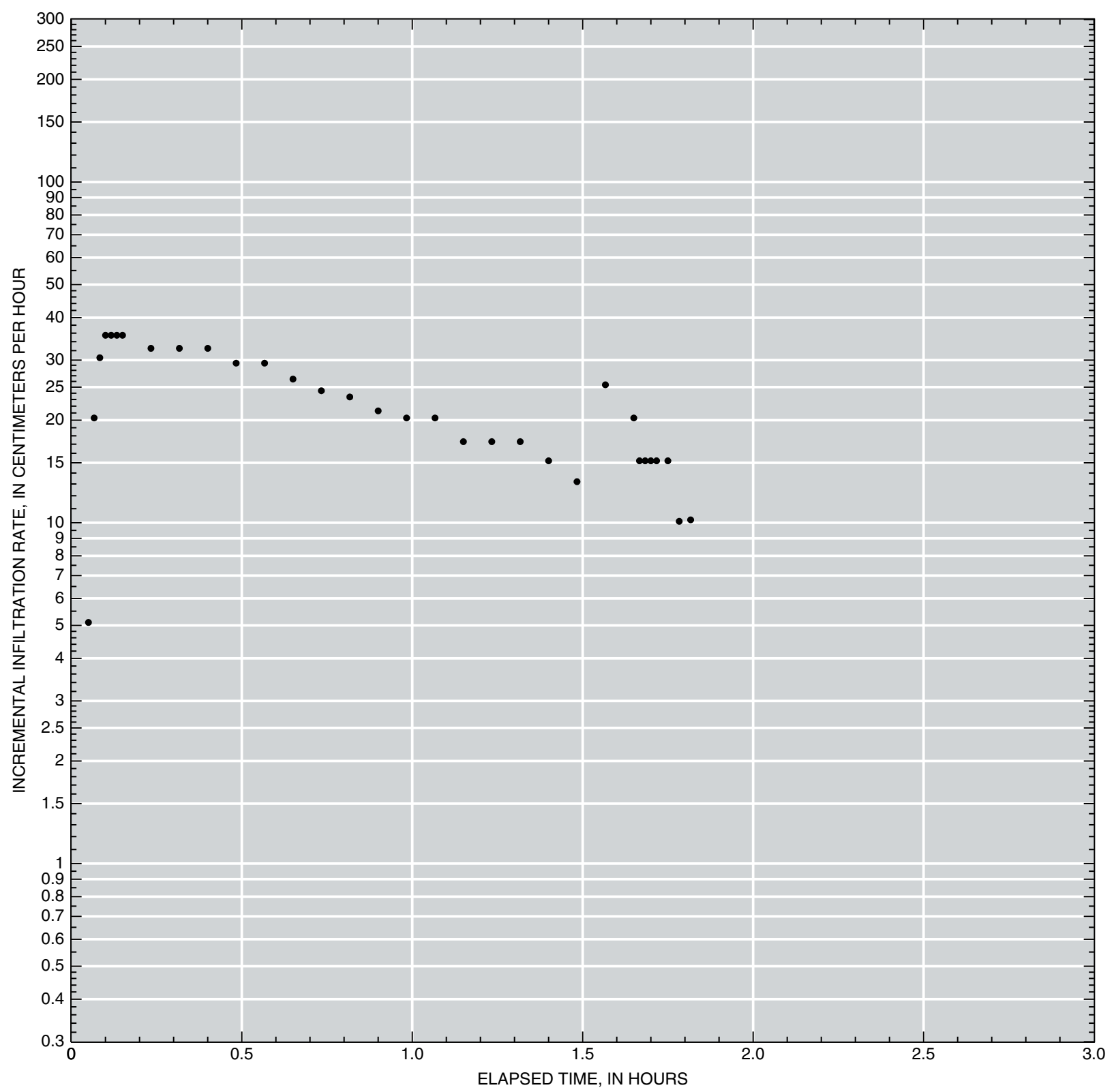

Incremental infiltration rate (velocity) is calculated as:

$\mathrm{V}=\mathrm{dV} /(\mathrm{A} * \mathrm{dt})$

where:

$\mathrm{v}=$ incremental infiltration velocity, in centimeters per hour,

$\mathrm{dV}=$ volume of water used during time interval to maintain constant head, in milliliters,

$A=$ area of ring infiltrometer, in square centimeters,

$d t=$ time interval, in hours.

Modified from American Society for Testing and Materials (1994)

Appendix 1-11. Infiltration data for site AFB2. 


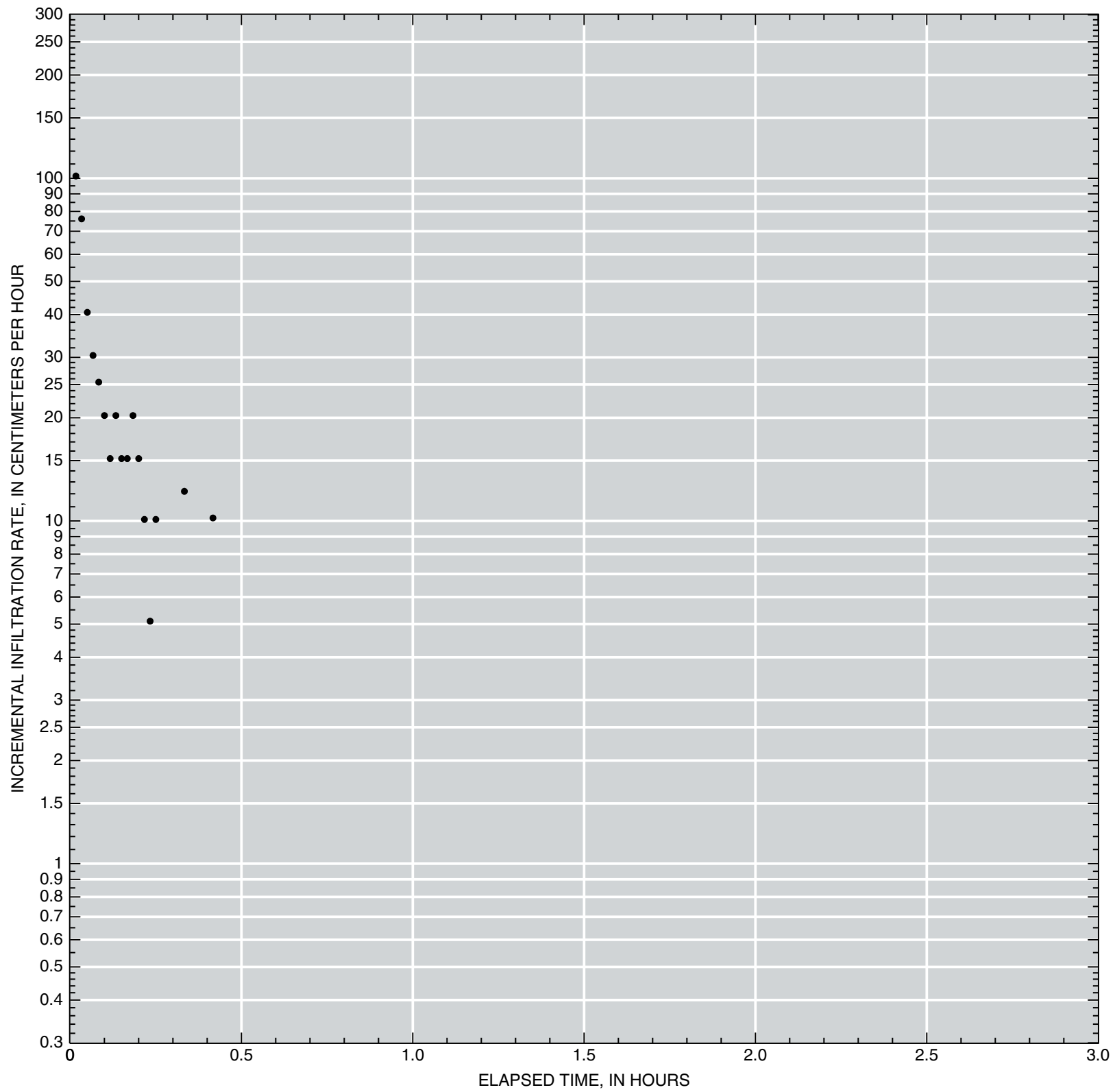

Incremental infiltration rate (velocity) is calculated as:

$\mathrm{V}=\mathrm{dV} /(\mathrm{A} * \mathrm{dt})$

where:

$\mathrm{v}=$ incremental infiltration velocity, in centimeters per hour,

$\mathrm{dV}=$ volume of water used during time interval to maintain constant head, in milliliters,

$A=$ area of ring infiltrometer, in square centimeters,

$d t=$ time interval, in hours.

Modified from American Society for Testing and Materials (1994)

Appendix 1-12. Infiltration data for site GC1. 


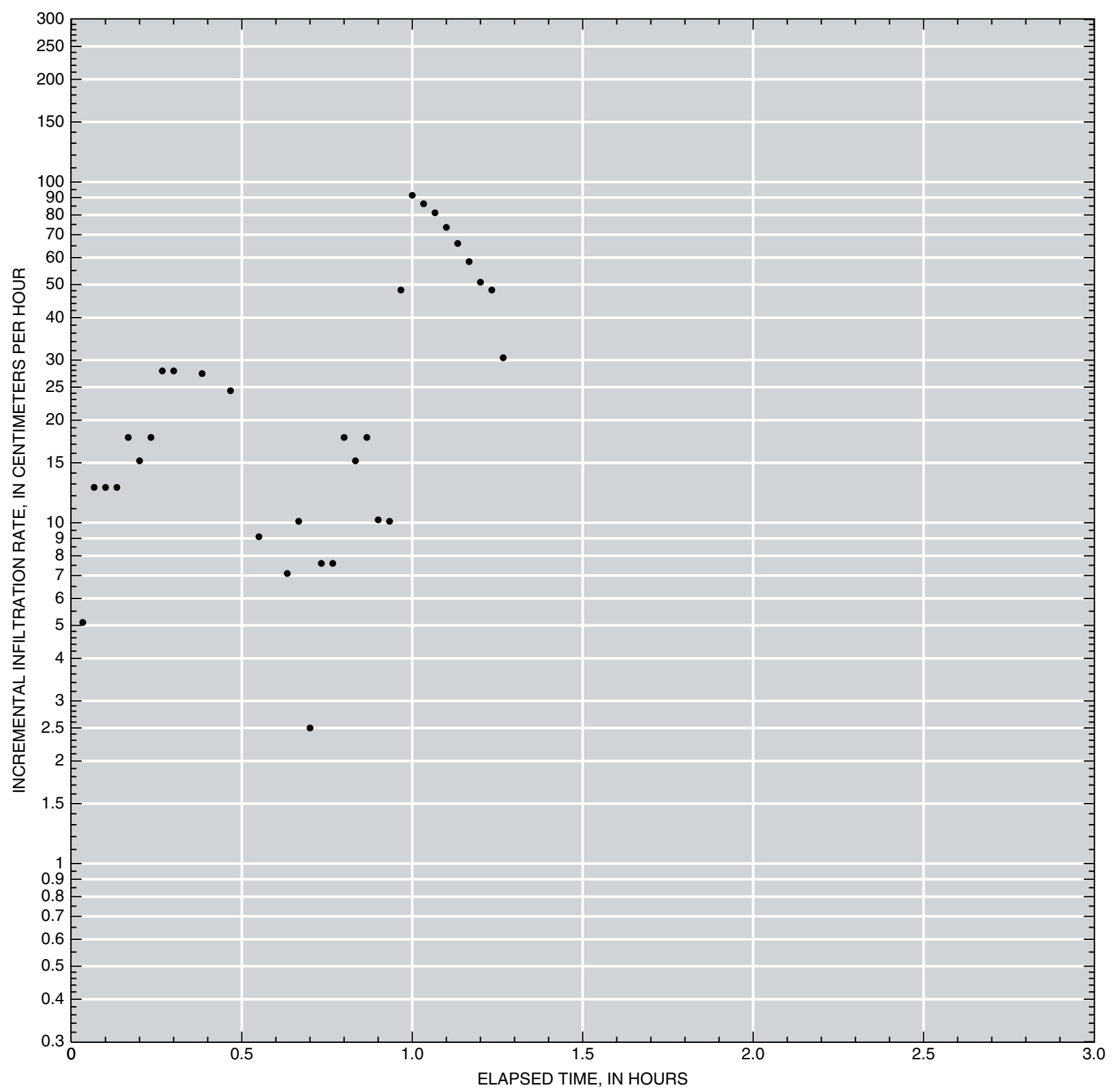

Incremental infiltration rate (velocity) is calculated as:

$\mathrm{v}=\mathrm{dV} /(\mathrm{A} * \mathrm{dt})$

where:

$\mathrm{v}=$ incremental infiltration velocity, in centimeters per hour,

$\mathrm{dV}=$ volume of water used during time interval to maintain constant head, in milliliters,

$A=$ area of ring infiltrometer, in square centimeters,

$d t=$ time interval, in hours.

Modified from American Society for Testing and Materials (1994)

Appendix 1-13. Infiltration data for site GC2. 


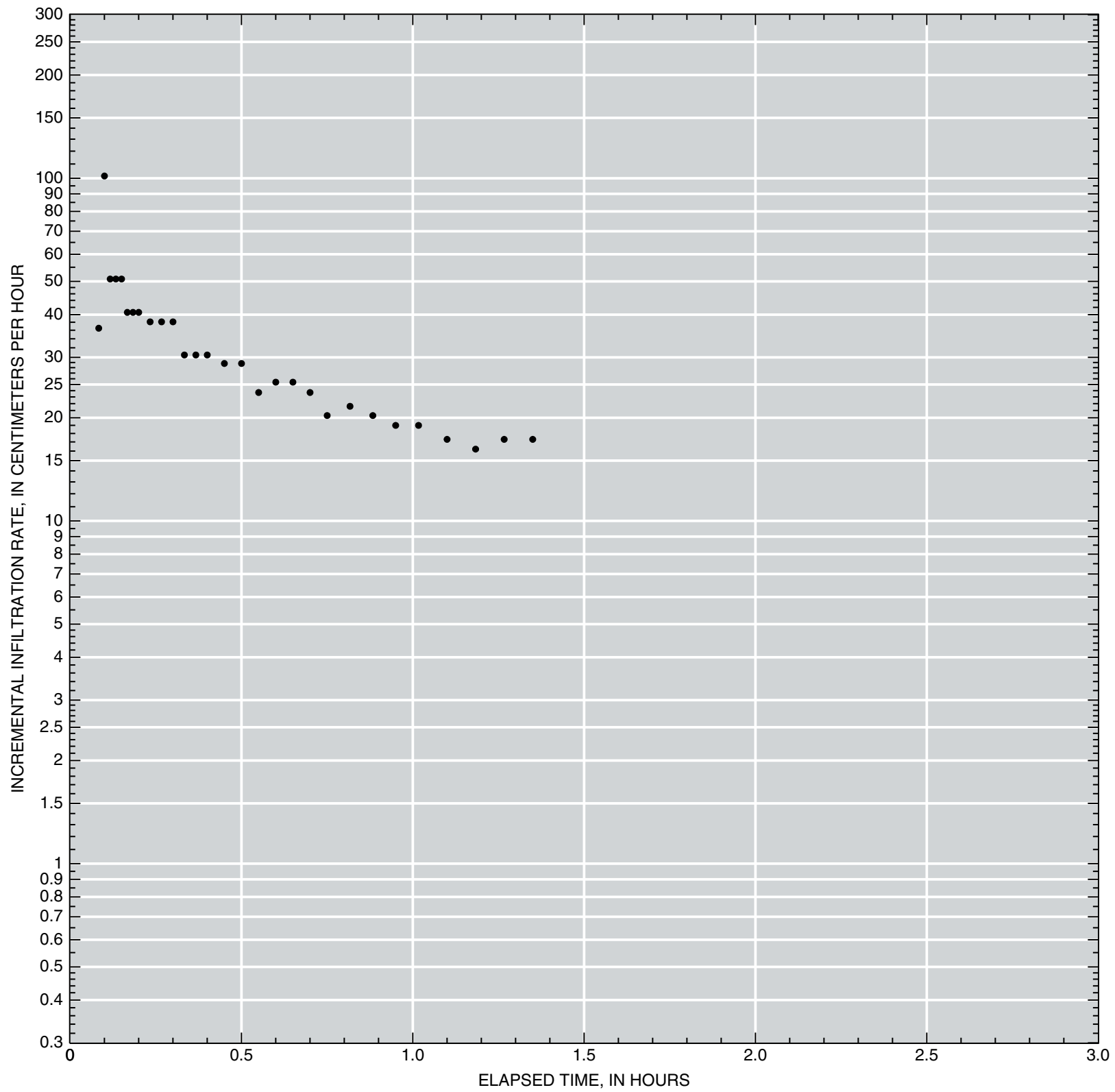

Incremental infiltration rate (velocity) is calculated as:

$\mathrm{V}=\mathrm{dV} /(\mathrm{A} * \mathrm{dt})$

where:

$\mathrm{v}=$ incremental infiltration velocity, in centimeters per hour,

$\mathrm{dV}=$ volume of water used during time interval to maintain constant head, in milliliters,

$A=$ area of ring infiltrometer, in square centimeters,

$d t=$ time interval, in hours.

Modified from American Society for Testing and Materials (1994)

Appendix 1-14. Infiltration data for site GC3. 


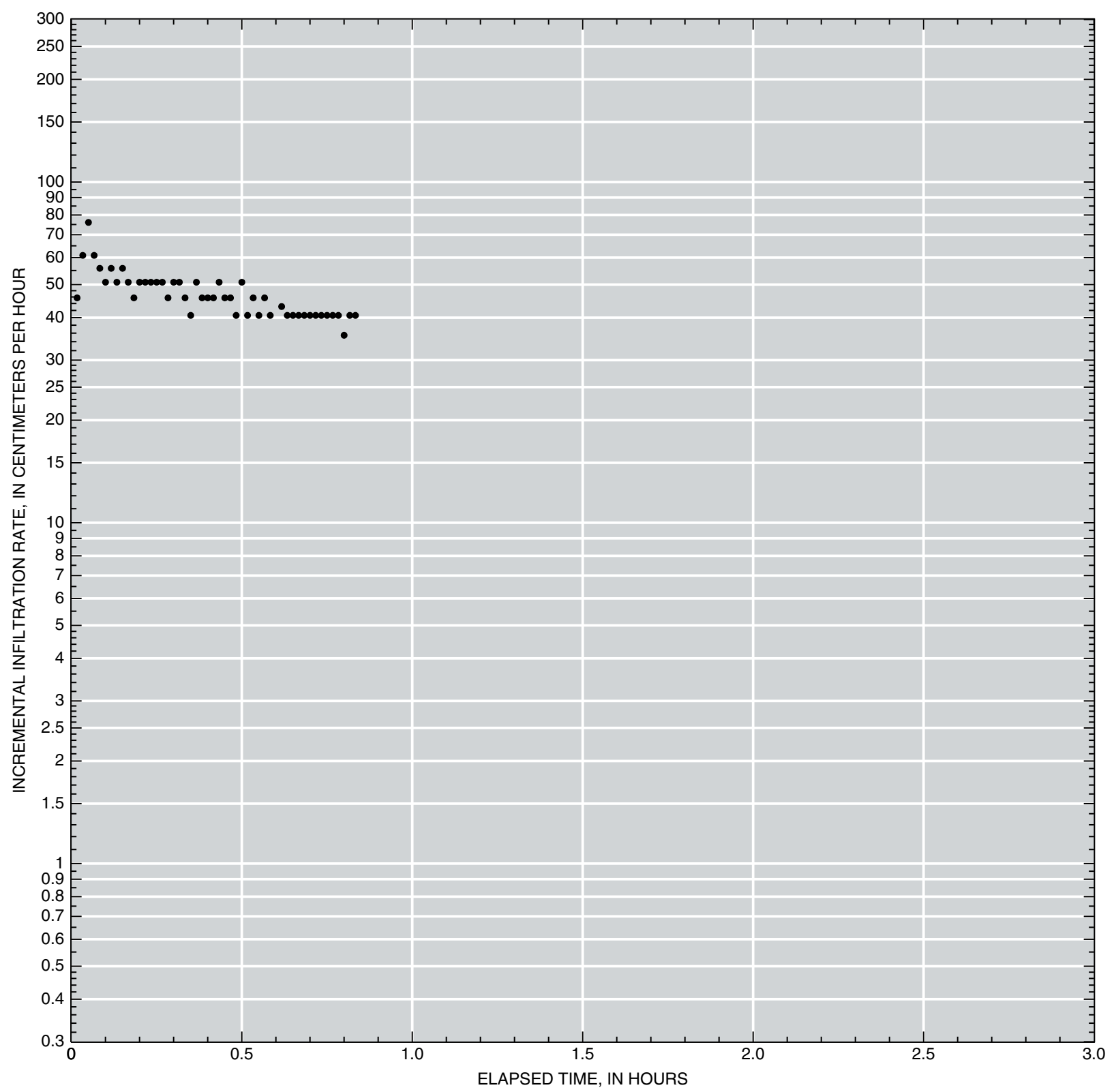

Incremental infiltration rate (velocity) is calculated as:

$\mathrm{v}=\mathrm{dV} /(\mathrm{A} * \mathrm{dt})$

where:

$\mathrm{v}=$ incremental infiltration velocity, in centimeters per hour,

$\mathrm{dV}=$ volume of water used during time interval to maintain constant head, in milliliters,

$A=$ area of ring infiltrometer, in square centimeters,

$d t=$ time interval, in hours.

Modified from American Society for Testing and Materials (1994)

Appendix 1-15. Infiltration data for site LG1. 


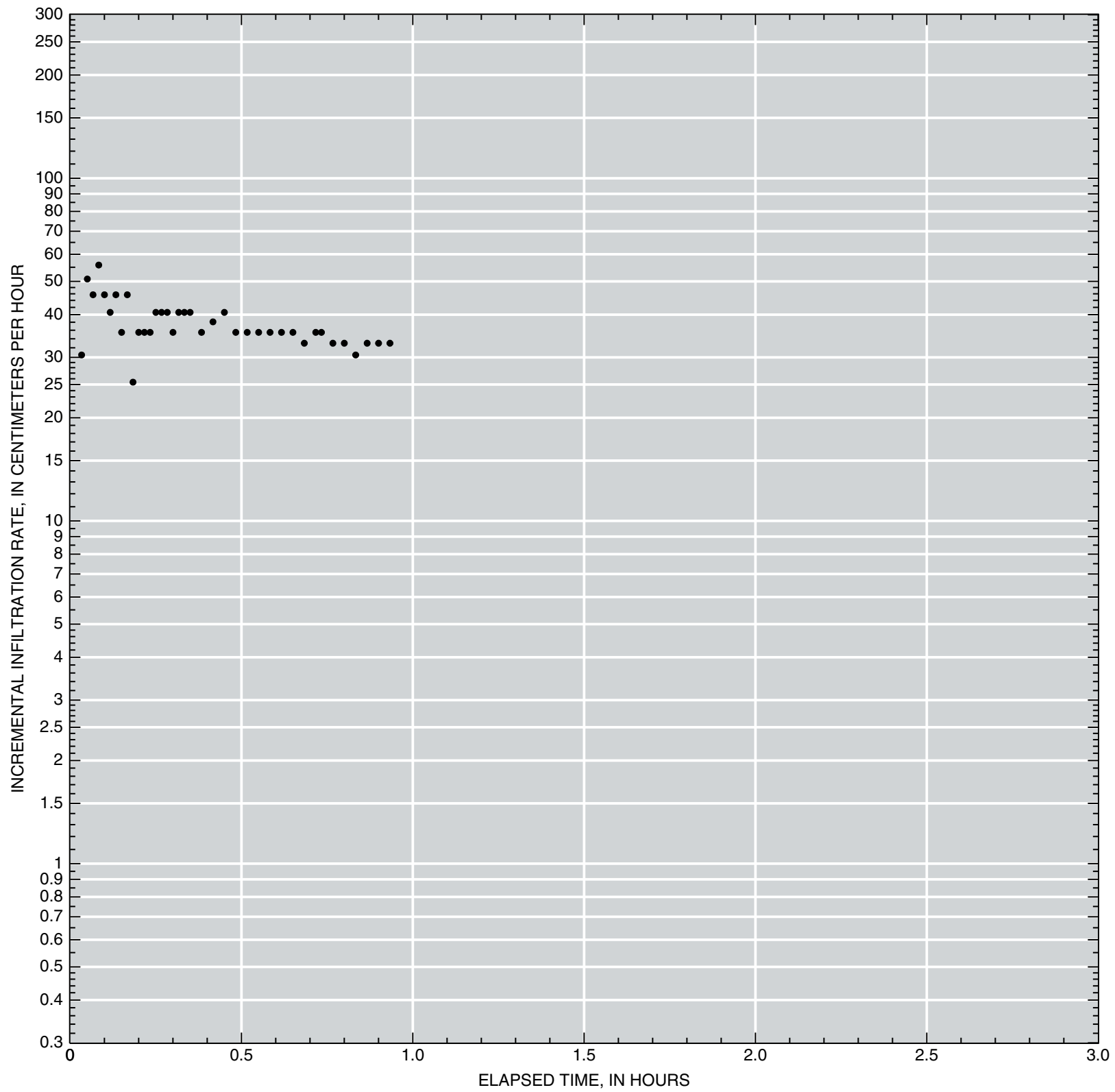

Incremental infiltration rate (velocity) is calculated as:

$\mathrm{V}=\mathrm{dV} /(\mathrm{A} * \mathrm{dt})$

where:

$\mathrm{v}=$ incremental infiltration velocity, in centimeters per hour,

$\mathrm{dV}=$ volume of water used during time interval to maintain constant head, in milliliters,

$A=$ area of ring infiltrometer, in square centimeters,

$d t=$ time interval, in hours.

Modified from American Society for Testing and Materials (1994)

Appendix 1-16. Infiltration data for site LG2. 


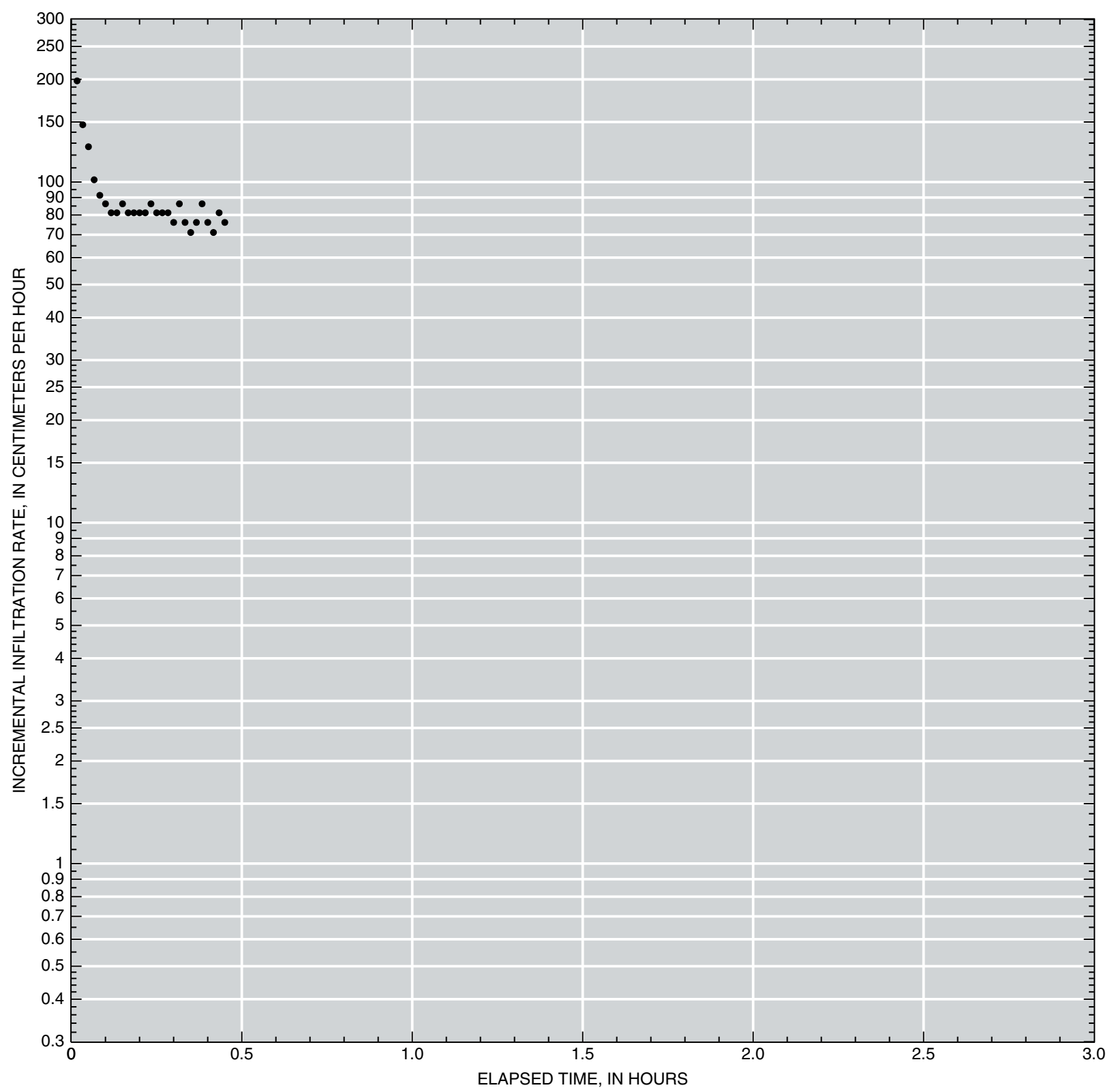

Incremental infiltration rate (velocity) is calculated as:

$\mathrm{v}=\mathrm{dV} /(\mathrm{A} * \mathrm{dt})$

where:

$\mathrm{v}=$ incremental infiltration velocity, in centimeters per hour,

$\mathrm{dV}=$ volume of water used during time interval to maintain constant head, in milliliters,

$A=$ area of ring infiltrometer, in square centimeters,

$d t=$ time interval, in hours.

Modified from American Society for Testing and Materials (1994)

Appendix 1-17. Infiltration data for site LG3. 


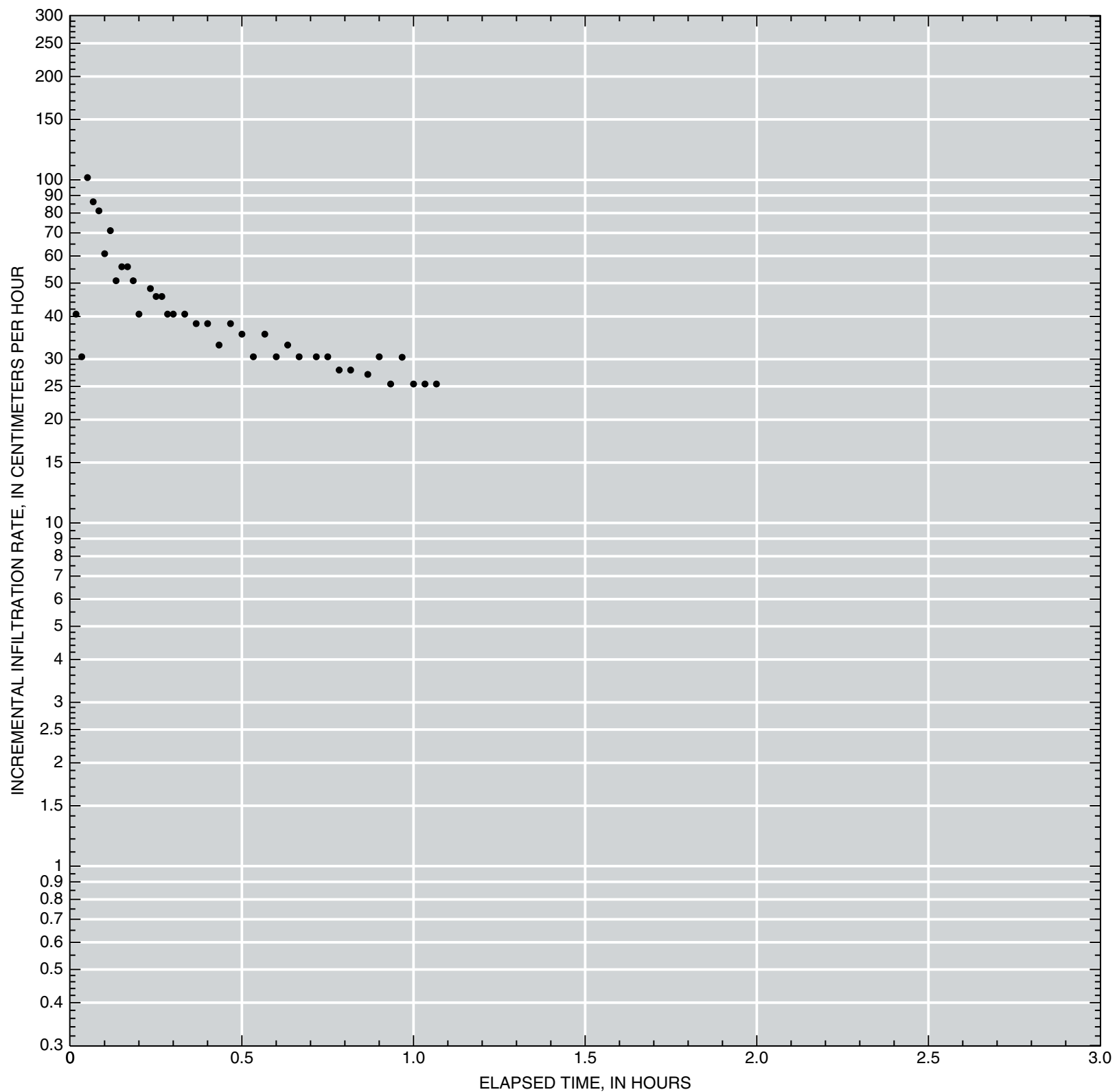

Incremental infiltration rate (velocity) is calculated as:

$\mathrm{V}=\mathrm{dV} /(\mathrm{A} * \mathrm{dt})$

where:

$\mathrm{v}=$ incremental infiltration velocity, in centimeters per hour,

$d V=$ volume of water used during time interval to maintain constant head, in milliliters,

$A=$ area of ring infiltrometer, in square centimeters,

$d t=$ time interval, in hours.

Modified from American Society for Testing and Materials (1994)

Appendix 1-18. Infiltration data for site LG4. 


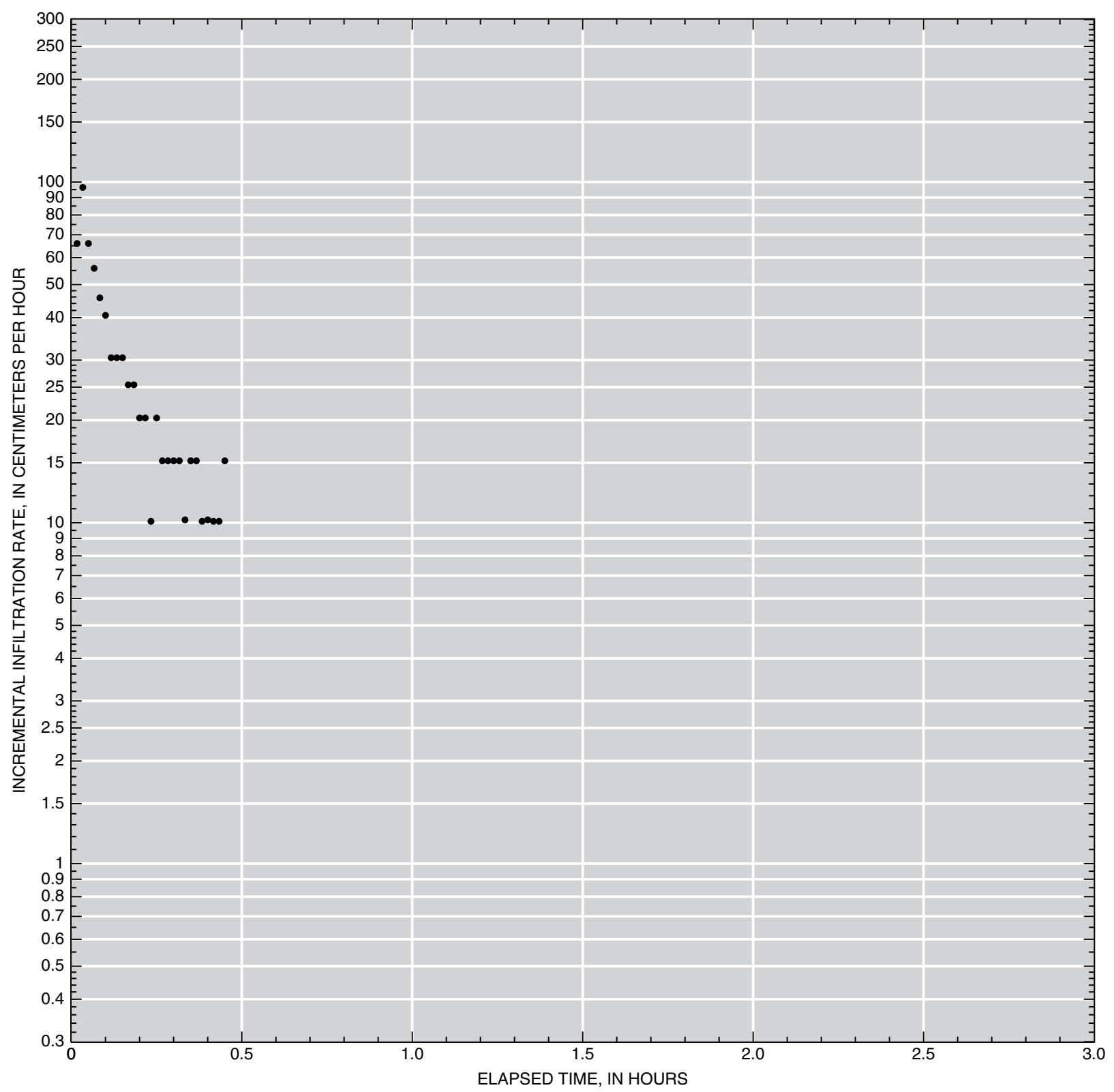

Incremental infiltration rate (velocity) is calculated as:

$\mathrm{v}=\mathrm{dV} /(\mathrm{A} * d \mathrm{t})$

where:

$\mathrm{v}=$ incremental infiltration velocity, in centimeters per hour,

$\mathrm{dV}=$ volume of water used during time interval to maintain constant head, in milliliters,

$A$ = area of ring infiltrometer, in square centimeters,

$d t=$ time interval, in hours.

Modified from American Society for Testing and Materials (1994)

Appendix 1-19. Infiltration data for site DC1. 


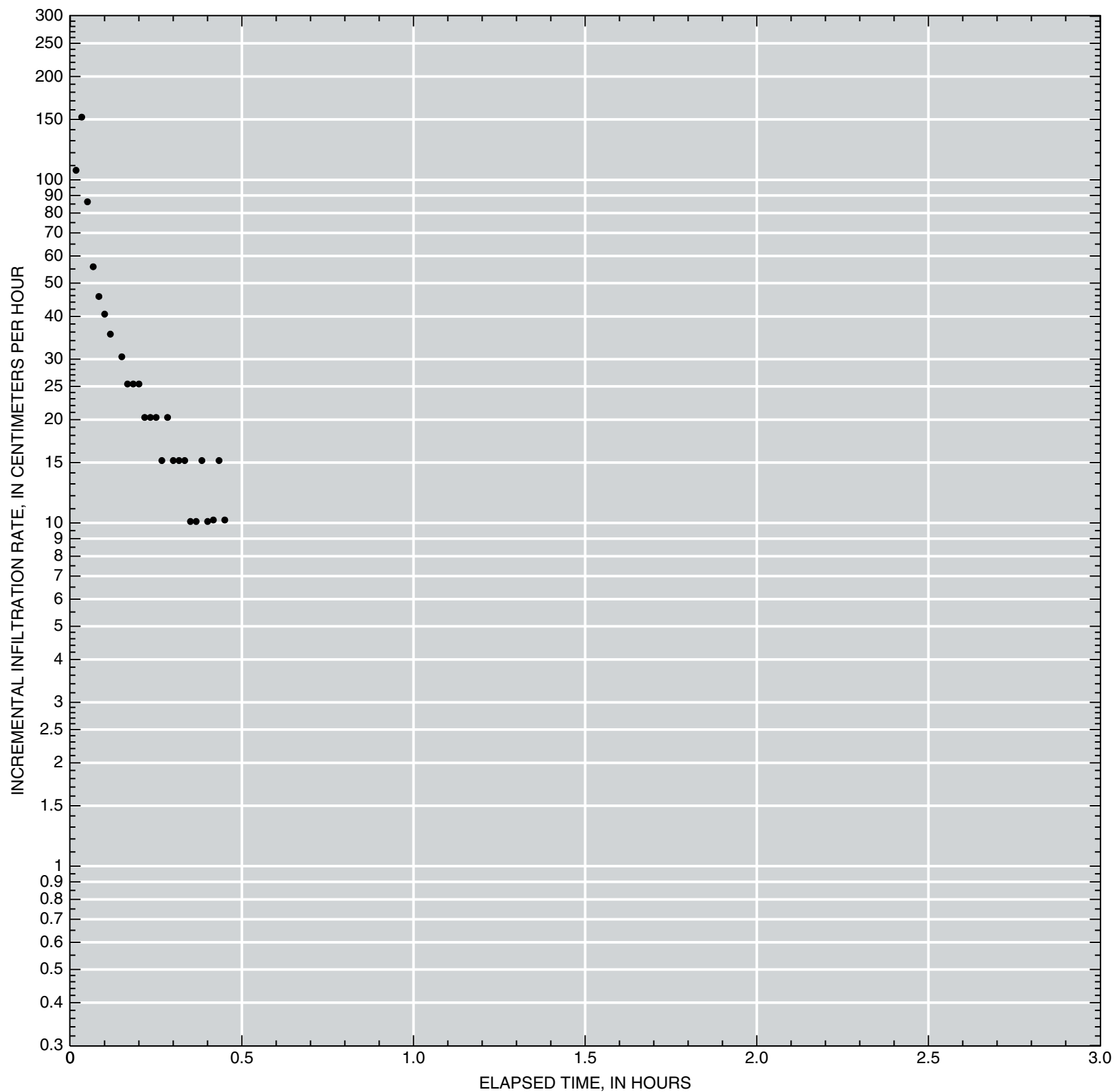

Incremental infiltration rate (velocity) is calculated as:

$\mathrm{V}=\mathrm{dV} /(\mathrm{A} * \mathrm{dt})$

where:

$\mathrm{v}=$ incremental infiltration velocity, in centimeters per hour,

$\mathrm{dV}=$ volume of water used during time interval to maintain constant head, in milliliters,

$A=$ area of ring infiltrometer, in square centimeters,

$d t=$ time interval, in hours.

Modified from American Society for Testing and Materials (1994)

Appendix 1-20. Infiltration data for site DC2. 


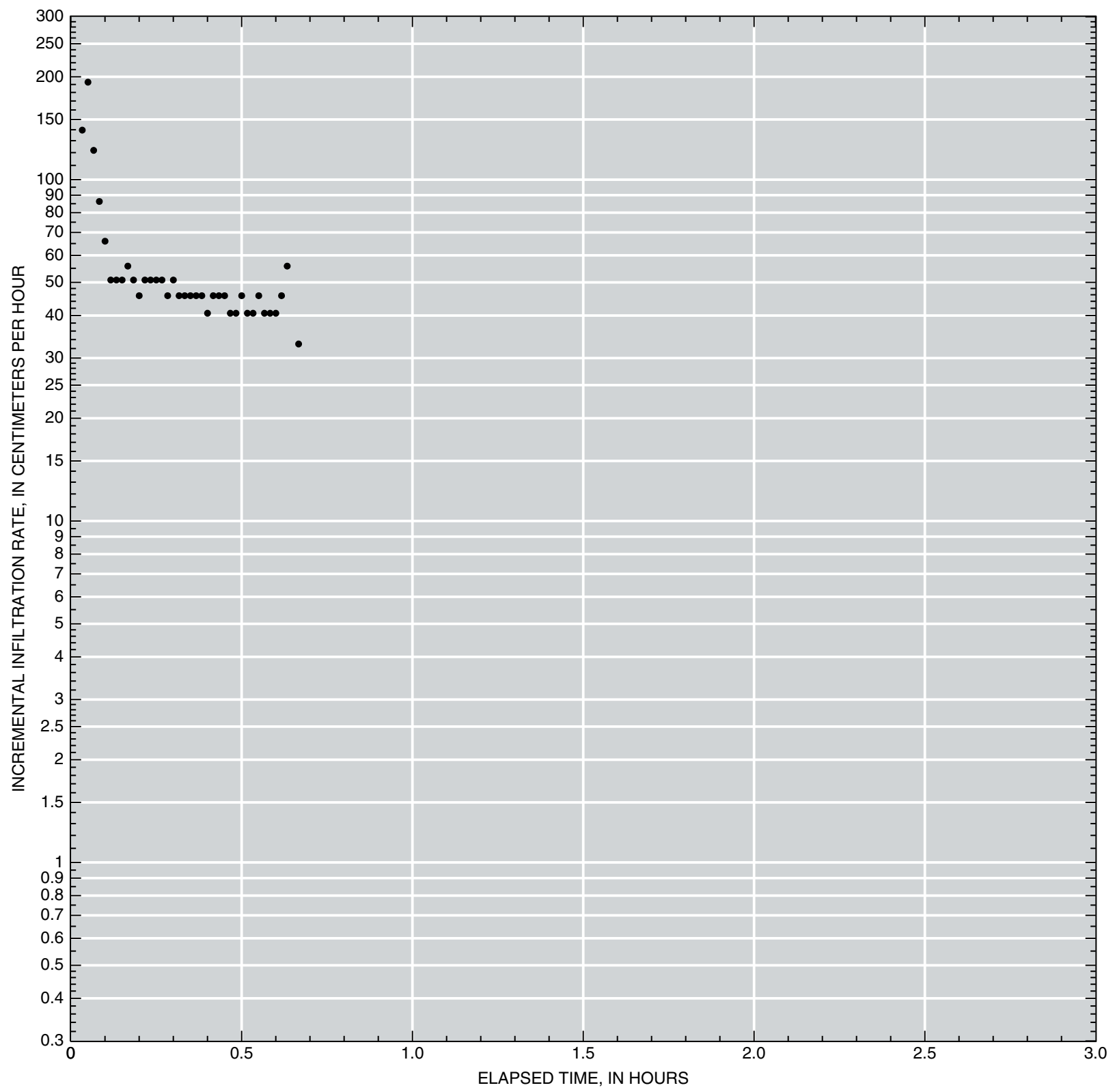

Incremental infiltration rate (velocity) is calculated as:

$\mathrm{v}=\mathrm{dV} /(\mathrm{A} * \mathrm{dt})$

where:

$\mathrm{v}=$ incremental infiltration velocity, in centimeters per hour,

$\mathrm{dV}=$ volume of water used during time interval to maintain constant head, in milliliters,

$A=$ area of ring infiltrometer, in square centimeters,

$d t=$ time interval, in hours.

Modified from American Society for Testing and Materials (1994)

Appendix 1-21. Infiltration data for site SP1. 


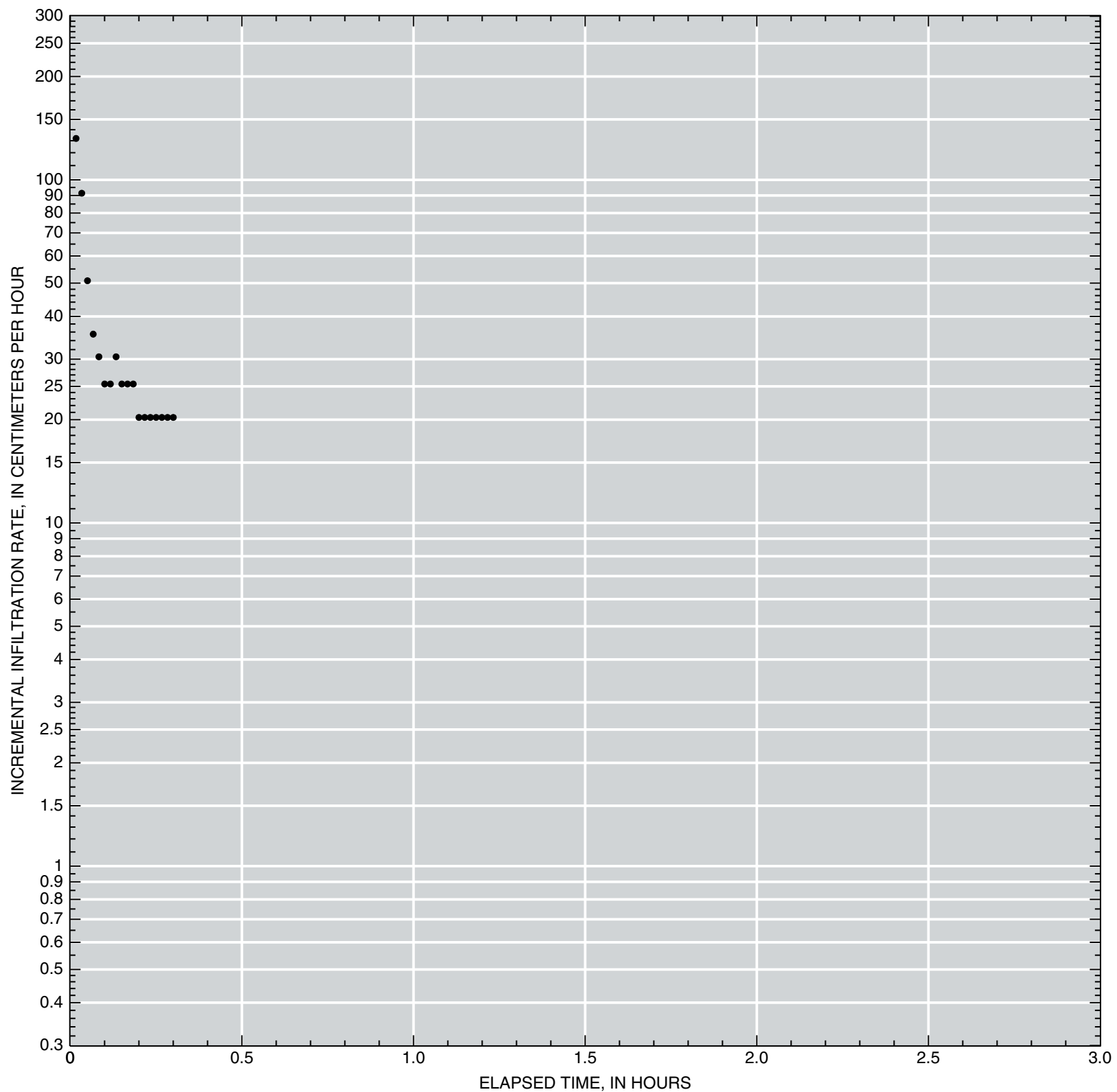

Incremental infiltration rate (velocity) is calculated as:

$\mathrm{V}=\mathrm{dV} /(\mathrm{A} * \mathrm{dt})$

where:

$\mathrm{v}=$ incremental infiltration velocity, in centimeters per hour,

$d V=$ volume of water used during time interval to maintain constant head, in milliliters,

$A=$ area of ring infiltrometer, in square centimeters,

$d t=$ time interval, in hours.

Modified from American Society for Testing and Materials (1994)

Appendix 1-22. Infiltration data for site SP2. 


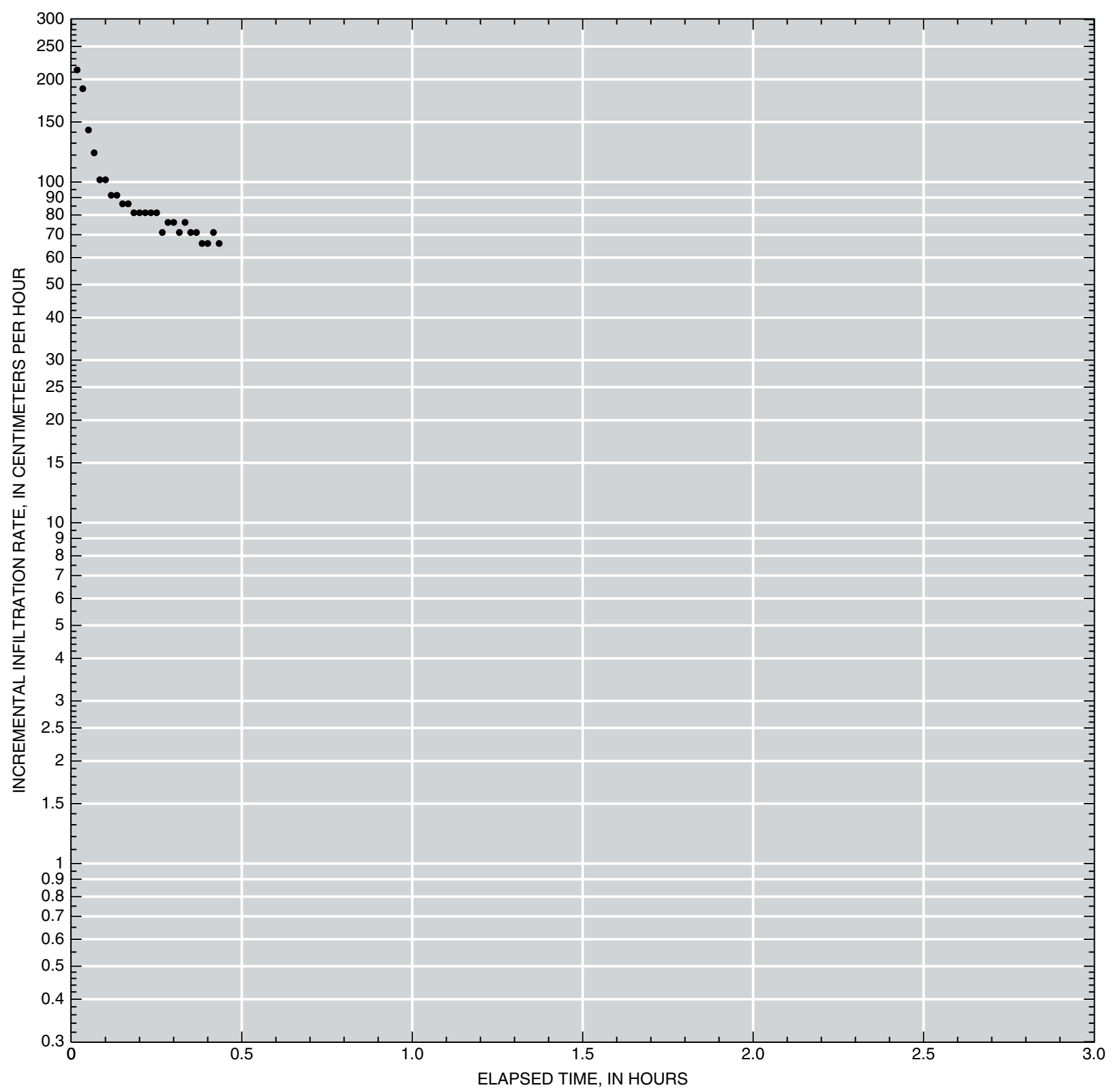

Incremental infiltration rate (velocity) is calculated as:

$\mathrm{V}=\mathrm{dV} /(\mathrm{A} * \mathrm{dt})$

where:

$\mathrm{v}=$ incremental infiltration velocity, in centimeters per hour,

$\mathrm{dV}=$ volume of water used during time interval to maintain constant head, in milliliters,

$A=$ area of ring infiltrometer, in square centimeters,

$d t=$ time interval, in hours.

Modified from American Society for Testing and Materials (1994)

Appendix 1-23. Infiltration data for site SP3. 


\section{Appendix 2. Infiltration Data}


Appendix 2-1. Infiltration data for site AD1.

[hrs, hours; min, minutes; $\mathrm{mL}$, milliliters; cm/hr, centimeters per hour; --, no data]

\begin{tabular}{|c|c|c|c|c|c|c|c|}
\hline \multicolumn{2}{|c|}{ Time } & \multirow[b]{2}{*}{ Tube (units) } & \multirow[b]{2}{*}{ Time } & \multicolumn{2}{|c|}{ Time } & \multicolumn{2}{|c|}{ Incremental } \\
\hline hrs & $\min$ & & & Interval (hrs) & Elapsed (hrs) & Volume (mL) & Velocity $(\mathrm{cm} / \mathrm{hr})$ \\
\hline 10 & 38 & 9.10 & 10.633 & -- & -- & -- & -- \\
\hline 10 & 39 & 9.60 & 10.650 & 0.017 & 0.017 & 1,250 & 25.4 \\
\hline 10 & 40 & 10.20 & 10.667 & .017 & .033 & 1,500 & 30.5 \\
\hline 10 & 41 & 10.60 & 10.683 & .017 & .050 & 1,000 & 20.3 \\
\hline 10 & 42 & 11.00 & 10.700 & .017 & .067 & 1,000 & 20.3 \\
\hline 10 & 43 & 11.40 & 10.717 & .017 & .083 & 1,000 & 20.3 \\
\hline 10 & 44 & 11.70 & 10.733 & .017 & .100 & 749 & 15.2 \\
\hline 10 & 45 & 12.00 & 10.750 & .017 & .117 & 750 & 15.2 \\
\hline 10 & 47 & 12.50 & 10.783 & .033 & .150 & 1,250 & 12.7 \\
\hline 10 & 51 & 13.50 & 10.850 & .067 & .217 & 2,500 & 12.7 \\
\hline 10 & 55 & 14.50 & 10.917 & .067 & .283 & 2,500 & 12.7 \\
\hline 11 & 00 & 15.60 & 11.000 & .083 & .367 & 2,750 & 11.2 \\
\hline 11 & 05 & 16.70 & 11.083 & .083 & .450 & 2,750 & 11.2 \\
\hline 11 & 10 & 18.00 & 11.167 & .083 & .533 & 3,250 & 13.2 \\
\hline 11 & 15 & 19.30 & 11.250 & .083 & .617 & 3,250 & 13.2 \\
\hline 11 & 20 & 20.40 & 11.333 & .083 & .700 & 2,749 & 11.2 \\
\hline 11 & 25 & 21.70 & 11.417 & .083 & .783 & 3,250 & 13.2 \\
\hline 11 & 30 & 22.90 & 11.500 & .083 & .867 & 3,000 & 12.2 \\
\hline 11 & 45 & 26.70 & 11.750 & .250 & 1.117 & 9,500 & 12.9 \\
\hline 12 & 00 & 30.50 & 12.000 & .250 & 1.367 & 9,500 & 12.9 \\
\hline 12 & 15 & 34.50 & 12.250 & .250 & 1.617 & 10,000 & 13.5 \\
\hline 12 & 30 & 38.80 & 12.500 & .250 & 1.867 & 10,750 & 14.6 \\
\hline 12 & 45 & 42.30 & 12.750 & .250 & 2.117 & 8,750 & 11.8 \\
\hline 13 & 00 & 46.20 & 13.000 & .250 & 2.367 & 9,750 & 13.2 \\
\hline 13 & 05 & 47.50 & 13.083 & .083 & 2.450 & 3,249 & 13.2 \\
\hline 13 & 10 & 48.90 & 13.167 & .083 & 2.533 & 3,500 & 14.2 \\
\hline 13 & 12 & 49.50 & 13.200 & .033 & 2.567 & 1,500 & 15.2 \\
\hline 13 & 13 & 49.80 & 13.217 & .017 & 2.583 & 749 & 15.2 \\
\hline
\end{tabular}

\begin{tabular}{|c|c|}
\hline \multicolumn{2}{|c|}{ Penetration } \\
\hline Ring & Depth (inches) \\
\hline Inner & 3.0 \\
\hline Outer & 1.5 \\
\hline \multicolumn{2}{|c|}{ Constant water level } \\
\hline Ring & Depth (feet) \\
\hline Inner & 0.30 \\
\hline Outer & 0.35 \\
\hline
\end{tabular}

\begin{tabular}{cc}
\hline \multicolumn{2}{c}{ Water temperature } \\
\hline Temperature (degrees Celsius) & Time \\
\hline 19.0 & $10: 47$ \\
21.5 & $12: 00$ \\
23.5 & $13: 13$ \\
\hline \multicolumn{2}{c}{ Soil temperature } \\
\hline Temperature (degrees Celsius) & Depth (inches) \\
\hline 22.0 & 5.0 \\
\hline
\end{tabular}

Comments: No evidence of rings leaking. 
Appendix 2-2. Infiltration data for site AD2.

[hrs, hours; min, minutes; $\mathrm{mL}$, milliliters; $\mathrm{cm} / \mathrm{hr}$, centimeters per hour; nd, no data; --, no data]

\begin{tabular}{|c|c|c|c|c|c|c|c|}
\hline \multicolumn{2}{|c|}{ Time } & \multirow[b]{2}{*}{ Tube (units) } & \multirow[b]{2}{*}{ Time } & \multicolumn{2}{|c|}{ Time } & \multicolumn{2}{|c|}{ Incremental } \\
\hline hrs & $\min$ & & & Interval (hrs) & Elapsed (hrs) & Volume (mL) & Velocity $(\mathrm{cm} / \mathrm{hr})$ \\
\hline 8 & 52 & -- & 8.867 & -- & -- & -- & -- \\
\hline 8 & 53 & 1.00 & 8.883 & 0.017 & 0.017 & 2,500 & 50.8 \\
\hline 8 & 54 & 1.60 & 8.900 & .017 & .033 & 1,500 & 30.5 \\
\hline 8 & 55 & 2.10 & 8.917 & .017 & .050 & 1,250 & 25.4 \\
\hline 8 & 56 & 2.50 & 8.933 & .017 & .067 & 1,000 & 20.3 \\
\hline 8 & 57 & 2.90 & 8.950 & .017 & .083 & 1,000 & 20.3 \\
\hline 8 & 58 & 3.30 & 8.967 & .017 & .100 & 1,000 & 20.3 \\
\hline 8 & 59 & 3.70 & 8.983 & .017 & .117 & 1,000 & 20.3 \\
\hline 9 & 00 & 4.10 & 9.000 & .017 & .133 & 999 & 20.3 \\
\hline 9 & 05 & 6.10 & 9.083 & .083 & .217 & 5,000 & 20.3 \\
\hline 9 & 10 & 8.30 & 9.167 & .083 & .300 & 5,500 & 22.3 \\
\hline 9 & 15 & 10.40 & 9.250 & .083 & .383 & 5,250 & 21.3 \\
\hline 9 & 20 & 12.50 & 9.333 & .083 & .467 & 5,250 & 21.3 \\
\hline 9 & 25 & 14.70 & 9.417 & .083 & .550 & 5,500 & 22.3 \\
\hline 9 & 30 & 16.80 & 9.500 & .083 & .633 & 5,250 & 21.3 \\
\hline 9 & 45 & 23.70 & 9.750 & .250 & .883 & 17,250 & 23.4 \\
\hline 10 & 00 & 30.60 & 10.000 & .250 & 1.133 & 17,250 & 23.4 \\
\hline 10 & 15 & 36.80 & 10.250 & .250 & 1.383 & 15,500 & 21.0 \\
\hline 10 & 30 & 44.20 & 10.500 & .250 & 1.633 & 18,500 & 25.0 \\
\hline 10 & 35 & 47.20 & 10.583 & .083 & 1.717 & 7,500 & 30.5 \\
\hline 10 & 36 & 47.70 & 10.600 & .017 & 1.733 & 1,250 & 25.4 \\
\hline 10 & 37 & 48.20 & 10.617 & .017 & 1.750 & 1,250 & 25.4 \\
\hline 10 & 38 & 48.70 & 10.633 & .017 & 1.767 & 1,250 & 25.4 \\
\hline 10 & 39 & 49.10 & 10.650 & .017 & 1.783 & 999 & 20.3 \\
\hline 10 & 40 & 49.60 & 10.667 & .017 & 1.800 & 1,250 & 25.4 \\
\hline
\end{tabular}

\begin{tabular}{|c|c|}
\hline \multicolumn{2}{|c|}{ Penetration } \\
\hline Ring & Depth (inches) \\
\hline Inner & 3.5 \\
\hline Outer & 3.0 \\
\hline \multicolumn{2}{|c|}{ Constant water level } \\
\hline Ring & Depth (inches) \\
\hline Inner & 3.0 \\
\hline Outer & 3.0 \\
\hline
\end{tabular}

\begin{tabular}{cc}
\hline \multicolumn{2}{c}{ Water temperature } \\
\hline Temperature (degrees Celsius) & Time \\
\hline 16.0 & $09: 05$ \\
16.5 & $09: 25$ \\
18.0 & $10: 40$ \\
\hline \multicolumn{2}{c}{ Soil temperature } \\
\hline Temperature (degrees Celsius) & Depth (inches) \\
\hline 19.0 & 5.8 \\
\hline
\end{tabular}

Comments: No evidence of rings leaking. 
Appendix 2-3. Infiltration data for site AD3.

[hrs, hours; min, minutes; $\mathrm{mL}$, milliliters; cm/hr, centimeters per hour; --, no data]

\begin{tabular}{|c|c|c|c|c|c|c|c|}
\hline \multicolumn{2}{|c|}{ Time } & \multirow[b]{2}{*}{ Tube (units) } & \multirow[b]{2}{*}{ Time } & \multicolumn{2}{|c|}{ Time } & \multicolumn{2}{|c|}{ Incremental } \\
\hline hrs & $\min$ & & & Interval (hrs) & Elapsed (hrs) & Volume (mL) & Velocity $(\mathrm{cm} / \mathrm{hr})$ \\
\hline 11 & 29 & 0.10 & 11.483 & -- & -- & -- & -- \\
\hline 11 & 34 & 0.60 & 11.567 & 0.083 & 0.083 & 1,250 & 5.1 \\
\hline 11 & 36 & 1.70 & 11.600 & .033 & .117 & 2,750 & 27.9 \\
\hline 11 & 37 & 2.30 & 11.617 & .017 & .133 & 1,500 & 30.5 \\
\hline 11 & 38 & 2.90 & 11.633 & .017 & .150 & 1,500 & 30.5 \\
\hline 11 & 39 & 3.50 & 11.650 & .017 & .167 & 1,500 & 30.5 \\
\hline 11 & 40 & 4.00 & 11.667 & .017 & .183 & 1,250 & 25.4 \\
\hline 11 & 41 & 4.60 & 11.683 & .017 & .200 & 1,500 & 30.5 \\
\hline 11 & 42 & 5.20 & 11.700 & .017 & .217 & 1,500 & 30.5 \\
\hline 11 & 43 & 5.70 & 11.717 & .017 & .233 & 1,250 & 25.4 \\
\hline 11 & 44 & 6.20 & 11.733 & .017 & .250 & 1,250 & 25.4 \\
\hline 11 & 45 & 6.90 & 11.750 & .017 & .267 & 1,750 & 35.5 \\
\hline 11 & 50 & 9.70 & 11.833 & .083 & .350 & 7,000 & 28.4 \\
\hline 11 & 55 & 12.50 & 11.917 & .083 & .433 & 7,000 & 28.4 \\
\hline 12 & & 15.30 & 12.000 & .083 & .517 & 7,000 & 28.4 \\
\hline 12 & 5 & 18.10 & 12.083 & .083 & .600 & 7,000 & 28.4 \\
\hline 12 & 10 & 20.80 & 12.167 & .083 & .683 & 6,750 & 27.4 \\
\hline 12 & 15 & 23.50 & 12.250 & .083 & .767 & 6,750 & 27.4 \\
\hline 12 & 30 & 31.70 & 12.500 & .250 & 1.017 & 20,500 & 27.7 \\
\hline 12 & 45 & 39.40 & 12.750 & .250 & 1.267 & 19,250 & 26.1 \\
\hline 13 & & 46.90 & 13.000 & .250 & 1.517 & 18,750 & 25.4 \\
\hline 13 & 1 & 47.50 & 13.017 & .017 & 1.533 & 1,500 & 30.5 \\
\hline 13 & 2 & 48.10 & 13.033 & .017 & 1.550 & 1,500 & 30.5 \\
\hline 13 & 3 & 48.60 & 13.050 & .017 & 1.567 & 1,250 & 25.4 \\
\hline
\end{tabular}

\begin{tabular}{|c|c|}
\hline \multicolumn{2}{|c|}{ Penetration } \\
\hline Ring & Depth (inches) \\
\hline Inner & 4.0 \\
\hline Outer & 4.0 \\
\hline \multicolumn{2}{|c|}{ Constant water level } \\
\hline Ring & Depth (inches) \\
\hline Inner & 2.25 \\
\hline Outer & 2.25 \\
\hline
\end{tabular}

\begin{tabular}{cc}
\hline \multicolumn{2}{c}{ Water temperature } \\
\hline Temperature (degrees Celsius) & Time \\
\hline 19.0 & $11: 38$ \\
20.5 & $12: 05$ \\
22.0 & $13: 04$ \\
\hline \multicolumn{2}{c}{ Soil temperature } \\
\hline Temperature (degrees Celsius) & Depth (inches) \\
\hline 22.0 & 5.0 \\
\hline
\end{tabular}

Comments: No evidence of rings leaking. 
Appendix 2-4. Infiltration data for site ARS1.

[hrs, hours; min, minutes; $\mathrm{mL}$, milliliters; $\mathrm{cm} / \mathrm{hr}$, centimeters per hour; --, no data]

\begin{tabular}{|c|c|c|c|c|c|c|c|}
\hline \multicolumn{2}{|c|}{ Time } & \multirow[b]{2}{*}{ Tube (units) } & \multirow[b]{2}{*}{ Time } & \multicolumn{2}{|c|}{ Time } & \multicolumn{2}{|c|}{ Incremental } \\
\hline hrs & $\min$ & & & Interval (hrs) & Elapsed (hrs) & Volume (mL) & Velocity $(\mathrm{cm} / \mathrm{hr})$ \\
\hline 8 & 40 & 0.30 & 8.667 & -- & -- & -- & -- \\
\hline 8 & 42 & 0.30 & 8.700 & 0.033 & 0.033 & -- & -- \\
\hline 8 & 44 & 0.30 & 8.733 & .033 & .067 & -- & -- \\
\hline 8 & 46 & 0.30 & 8.767 & .033 & .100 & -- & -- \\
\hline 8 & 48 & 0.50 & 8.800 & .033 & .133 & 500 & 5.1 \\
\hline 8 & 49 & 0.70 & 8.817 & .017 & .150 & 500 & 10.2 \\
\hline 8 & 50 & 1.00 & 8.833 & .017 & .167 & 750 & 15.2 \\
\hline 8 & 51 & 1.30 & 8.850 & .017 & .183 & 750 & 15.2 \\
\hline 8 & 52 & 1.60 & 8.867 & .017 & .200 & 750 & 15.2 \\
\hline 8 & 53 & 1.90 & 8.883 & .017 & .217 & 750 & 15.2 \\
\hline 8 & 54 & 2.20 & 8.900 & .017 & .233 & 750 & 15.2 \\
\hline 8 & 55 & 2.60 & 8.917 & .017 & .250 & 1,000 & 20.3 \\
\hline 8 & 56 & 2.90 & 8.933 & .017 & .267 & 750 & 15.2 \\
\hline 8 & 57 & 3.20 & 8.950 & .017 & .283 & 750 & 15.2 \\
\hline 8 & 58 & 3.50 & 8.967 & .017 & .300 & 750 & 15.2 \\
\hline 8 & 59 & 3.70 & 8.983 & .017 & .317 & 500 & 10.2 \\
\hline 9 & 00 & 4.00 & 9.000 & .017 & .333 & 750 & 15.2 \\
\hline 9 & 05 & 5.60 & 9.083 & .083 & .417 & 4,000 & 16.2 \\
\hline 9 & 10 & 7.30 & 9.167 & .083 & .500 & 4,250 & 17.3 \\
\hline 9 & 15 & 8.90 & 9.250 & .083 & .583 & 4,000 & 16.2 \\
\hline 9 & 20 & 10.60 & 9.333 & .083 & .667 & 4,250 & 17.3 \\
\hline 9 & 25 & 12.10 & 9.417 & .083 & .750 & 3,750 & 15.2 \\
\hline 9 & 30 & 13.60 & 9.500 & .083 & .833 & 3,750 & 15.2 \\
\hline 9 & 40 & 16.40 & 9.667 & .167 & 1.000 & 7,000 & 14.2 \\
\hline 9 & 51 & 19.00 & 9.850 & .183 & 1.183 & 6,500 & 12.0 \\
\hline 10 & 00 & 20.30 & 10.000 & .150 & 1.333 & 3,250 & 7.3 \\
\hline 10 & 15 & 23.30 & 10.250 & .250 & 1.583 & 7,500 & 10.2 \\
\hline 10 & 30 & 26.80 & 10.500 & .250 & 1.833 & 8,750 & 11.8 \\
\hline 10 & 45 & 29.40 & 10.750 & .250 & 2.083 & 6,499 & 8.8 \\
\hline 11 & 00 & 31.90 & 11.000 & .250 & 2.333 & 6,250 & 8.5 \\
\hline 11 & 15 & 33.80 & 11.250 & .250 & 2.583 & 4,750 & 6.4 \\
\hline 11 & 30 & 36.10 & 11.500 & .250 & 2.833 & 5,750 & 7.8 \\
\hline 11 & 45 & 38.40 & 11.750 & .250 & 3.083 & 5,749 & 7.8 \\
\hline 12 & 00 & 40.40 & 12.000 & .250 & 3.333 & 5,000 & 6.8 \\
\hline 12 & 15 & 41.70 & 12.250 & .250 & 3.583 & 3,250 & 4.4 \\
\hline 12 & 30 & 44.20 & 12.500 & .250 & 3.833 & 6,250 & 8.5 \\
\hline 12 & 45 & 46.40 & 12.750 & .250 & 4.083 & 5,499 & 7.4 \\
\hline 13 & 00 & 48.50 & 13.000 & .250 & 4.333 & 5,250 & 7.1 \\
\hline
\end{tabular}


Appendix 2-4. Infiltration data for site ARS1.-Continued

\begin{tabular}{|c|c|}
\hline \multicolumn{2}{|c|}{ Penetration } \\
\hline Ring & Depth (inches) \\
\hline Inner & 4.5 \\
\hline Outer & 2.5 \\
\hline \multicolumn{2}{|c|}{ Constant water level } \\
\hline Ring & Depth (inches) \\
\hline Inner & 2.25 \\
\hline Outer & 2.25 \\
\hline
\end{tabular}

\begin{tabular}{cc}
\hline \multicolumn{2}{c}{ Water temperature } \\
\hline Temperature (degrees Celsius) & Time \\
\hline 18.0 & $08: 46$ \\
23.0 & $11: 15$ \\
27.0 & $13: 00$ \\
\hline \multicolumn{2}{c}{ Soil temperature } \\
\hline Temperature (degrees Celsius) & Depth (inches) \\
\hline 19.0 & 4.5 \\
\hline
\end{tabular}

Comments: Inner ring initial fill depth 3 inches. 
Appendix 2-5. Infiltration data for site ARS2.

[hrs, hours; min, minutes; $\mathrm{mL}$, milliliters; $\mathrm{cm} / \mathrm{hr}$, centimeters per hour; --, no data]

\begin{tabular}{|c|c|c|c|c|c|c|c|}
\hline \multicolumn{2}{|c|}{ Time } & \multirow[b]{2}{*}{ Tube (units) } & \multirow[b]{2}{*}{ Time } & \multicolumn{2}{|c|}{ Time } & \multicolumn{2}{|c|}{ Incremental } \\
\hline hrs & $\min$ & & & Interval (hrs) & Elapsed (hrs) & Volume (mL) & Velocity $(\mathrm{cm} / \mathrm{hr})$ \\
\hline 13 & 34 & 0.60 & 13.567 & -- & -- & -- & -- \\
\hline 13 & 35 & 0.60 & 13.583 & 0.017 & 0.017 & -- & -- \\
\hline 13 & 36 & 0.60 & 13.600 & .017 & .033 & -- & -- \\
\hline 13 & 37 & 0.60 & 13.617 & .017 & .050 & -- & -- \\
\hline 13 & 38 & 0.60 & 13.633 & .017 & .067 & -- & -- \\
\hline 13 & 39 & 0.70 & 13.650 & .017 & .083 & 250 & 5.1 \\
\hline 13 & 40 & 1.00 & 13.667 & .017 & .100 & 750 & 15.2 \\
\hline 13 & 41 & 1.30 & 13.683 & .017 & .117 & 750 & 15.2 \\
\hline 13 & 42 & 1.60 & 13.700 & .017 & .133 & 750 & 15.2 \\
\hline 13 & 43 & 2.00 & 13.717 & .017 & .150 & 1,000 & 20.3 \\
\hline 13 & 44 & 2.30 & 13.733 & .017 & .167 & 750 & 15.2 \\
\hline 13 & 45 & 2.60 & 13.750 & .017 & .183 & 750 & 15.2 \\
\hline 13 & 50 & 3.90 & 13.833 & .083 & .267 & 3,250 & 13.2 \\
\hline 13 & 55 & 5.20 & 13.917 & .083 & .350 & 3,250 & 13.2 \\
\hline 14 & 00 & 6.50 & 14.000 & .083 & .433 & 3,250 & 13.2 \\
\hline 14 & 05 & 7.60 & 14.083 & .083 & .517 & 2,750 & 11.2 \\
\hline 14 & 10 & 8.80 & 14.167 & .083 & .600 & 3,000 & 12.2 \\
\hline 14 & 15 & 9.90 & 14.250 & .083 & .683 & 2,750 & 11.2 \\
\hline 14 & 20 & 10.90 & 14.333 & .083 & .767 & 2,500 & 10.2 \\
\hline 14 & 25 & 11.90 & 14.417 & .083 & .850 & 2,500 & 10.2 \\
\hline 14 & 30 & 12.40 & 14.500 & .083 & .933 & 1,250 & 5.1 \\
\hline 14 & 35 & 13.20 & 14.583 & .083 & 1.017 & 2,000 & 8.1 \\
\hline 14 & 40 & 14.00 & 14.667 & .083 & 1.100 & 2,000 & 8.1 \\
\hline 14 & 45 & 14.60 & 14.750 & .083 & 1.183 & 1,500 & 6.1 \\
\hline 14 & 50 & 15.10 & 14.833 & .083 & 1.267 & 1,250 & 5.1 \\
\hline 14 & 55 & 15.70 & 14.917 & .083 & 1.350 & 1,500 & 6.1 \\
\hline 15 & 00 & 16.20 & 15.000 & .083 & 1.433 & 1,250 & 5.1 \\
\hline 15 & 5 & 16.70 & 15.083 & .083 & 1.517 & 1,250 & 5.1 \\
\hline 15 & 15 & 17.60 & 15.250 & .167 & 1.683 & 2,250 & 4.6 \\
\hline 15 & 25 & 18.30 & 15.417 & .167 & 1.850 & 1,750 & 3.6 \\
\hline 15 & 35 & 19.20 & 15.583 & .167 & 2.017 & 2,250 & 4.6 \\
\hline 15 & 46 & 20.00 & 15.767 & .183 & 2.200 & 2,000 & 3.7 \\
\hline 16 & 00 & 21.00 & 16.000 & .233 & 2.433 & 2,500 & 3.6 \\
\hline 16 & 15 & 21.40 & 16.250 & .250 & 2.683 & 999 & 1.4 \\
\hline 16 & 30 & 22.60 & 16.500 & .250 & 2.933 & 3,000 & 4.1 \\
\hline 16 & 45 & 23.60 & 16.750 & .250 & 3.183 & 2,500 & 3.4 \\
\hline 17 & 00 & 24.60 & 17.000 & .250 & 3.433 & 2,500 & 3.4 \\
\hline 17 & 15 & 25.60 & 17.250 & .250 & 3.683 & 2,500 & 3.4 \\
\hline
\end{tabular}


Soils Infiltration Data for Selected Wyoming Watersheds, 1998-99

Appendix 2-5. Infiltration data for site ARS2.-Continued

\begin{tabular}{|c|c|}
\hline \multicolumn{2}{|c|}{ Penetration } \\
\hline Ring & Depth (inches) \\
\hline Inner & 4.5 \\
\hline Outer & 2.5 \\
\hline \multicolumn{2}{|c|}{ Constant water level } \\
\hline Ring & Depth (inches) \\
\hline Inner & 2.25 \\
\hline Outer & 2.25 \\
\hline
\end{tabular}

\begin{tabular}{lc}
\hline \multicolumn{2}{c}{ Water temperature } \\
\hline Temperature (degrees Celsius) & Time \\
\hline 24.5 & $13: 50$ \\
28.5 & $15: 25$ \\
26.5 & $17: 15$ \\
\hline \multicolumn{2}{c}{ Soil temperature } \\
\hline Temperature (degrees Celsius) & Depth (inches) \\
\hline 24.0 & 4.5 \\
\hline
\end{tabular}

Comments: Inner ring initial fill depth 3 inches. 
Appendix 2-6. Infiltration data for site ARS3.

[hrs, hours; min, minutes; $\mathrm{mL}$, milliliters; $\mathrm{cm} / \mathrm{hr}$, centimeters per hour; --, no data]

\begin{tabular}{|c|c|c|c|c|c|c|c|}
\hline \multicolumn{2}{|c|}{ Time } & \multirow[b]{2}{*}{ Tube (units) } & \multirow[b]{2}{*}{ Time } & \multicolumn{2}{|c|}{ Time } & \multicolumn{2}{|c|}{ Incremental } \\
\hline hrs & $\min$ & & & Interval (hrs) & Elapsed (hrs) & Volume (mL) & Velocity $(\mathrm{cm} / \mathrm{hr})$ \\
\hline 8 & 29 & -- & 8.483 & -- & -- & -- & -- \\
\hline 8 & 30 & -- & 8.500 & 0.017 & 0.017 & -- & -- \\
\hline 8 & 31 & -- & 8.517 & .017 & .033 & -- & -- \\
\hline 8 & 32 & 0.10 & 8.533 & .017 & .050 & 250 & 5.1 \\
\hline 8 & 33 & .10 & 8.550 & .017 & .067 & -- & 0.0 \\
\hline 8 & 34 & .20 & 8.567 & .017 & .083 & 250 & 5.1 \\
\hline 8 & 35 & .20 & 8.583 & .017 & .100 & -- & -- \\
\hline 8 & 36 & .30 & 8.600 & .017 & .117 & 250 & 5.1 \\
\hline 8 & 37 & .40 & 8.617 & .017 & .133 & 250 & 5.1 \\
\hline 8 & 38 & .50 & 8.633 & .017 & .150 & 250 & 5.1 \\
\hline 8 & 39 & .55 & 8.650 & .017 & .167 & 125 & 2.5 \\
\hline 8 & 40 & .60 & 8.667 & .017 & .183 & 125 & 2.5 \\
\hline 8 & 45 & 1.10 & 8.750 & .083 & .267 & 1,250 & 5.1 \\
\hline 8 & 50 & 1.60 & 8.833 & .083 & .350 & 1,250 & 5.1 \\
\hline 8 & 55 & 2.90 & 8.917 & .083 & .433 & 3,250 & 13.2 \\
\hline 9 & 00 & 6.80 & 9.000 & .083 & .517 & 9,750 & 39.6 \\
\hline 9 & 05 & 8.50 & 9.083 & .083 & .600 & 4,250 & 17.3 \\
\hline 9 & 10 & 10.10 & 9.167 & .083 & .683 & 4,000 & 16.2 \\
\hline 9 & 15 & 11.70 & 9.250 & .083 & .767 & 4,000 & 16.2 \\
\hline 9 & 30 & 15.60 & 9.500 & .250 & 1.017 & 9,750 & 13.2 \\
\hline 9 & 40 & 18.10 & 9.667 & .167 & 1.183 & 6,250 & 12.7 \\
\hline 9 & 50 & 20.40 & 9.833 & .167 & 1.350 & 5,749 & 11.7 \\
\hline 10 & 00 & 22.50 & 10.000 & .167 & 1.517 & 5,250 & 10.7 \\
\hline 10 & 10 & 24.60 & 10.167 & .167 & 1.683 & 5,250 & 10.7 \\
\hline 10 & 20 & 26.50 & 10.333 & .167 & 1.850 & 4,750 & 9.6 \\
\hline 10 & 30 & 28.30 & 10.500 & .167 & 2.017 & 4,500 & 9.1 \\
\hline 10 & 45 & 30.80 & 10.750 & .250 & 2.267 & 6,250 & 8.5 \\
\hline 11 & 00 & 33.10 & 11.000 & .250 & 2.517 & 5,750 & 7.8 \\
\hline 11 & 15 & 34.60 & 11.250 & .250 & 2.767 & 3,750 & 5.1 \\
\hline 11 & 30 & 38.50 & 11.500 & .250 & 3.017 & 9,750 & 13.2 \\
\hline 11 & 45 & 40.40 & 11.750 & .250 & 3.267 & 4,750 & 6.4 \\
\hline 12 & 00 & 42.80 & 12.000 & .250 & 3.517 & 6,000 & 8.1 \\
\hline 12 & 15 & 44.90 & 12.250 & .250 & 3.767 & 5,250 & 7.1 \\
\hline 12 & 20 & 45.70 & 12.333 & .083 & 3.850 & 2,000 & 8.1 \\
\hline 12 & 25 & 46.30 & 12.417 & .083 & 3.933 & 1,499 & 6.1 \\
\hline 12 & 26 & 46.40 & 12.433 & .017 & 3.950 & 250 & 5.1 \\
\hline 12 & 28 & 46.70 & 12.467 & .033 & 3.983 & 750 & 7.6 \\
\hline 12 & 30 & 47.00 & 12.500 & .033 & 4.017 & 749 & 7.6 \\
\hline 12 & 32 & 47.30 & 12.533 & .033 & 4.050 & 749 & 7.6 \\
\hline
\end{tabular}


Soils Infiltration Data for Selected Wyoming Watersheds, 1998-99

Appendix 2-6. Infiltration data for site ARS3.-Continued

\begin{tabular}{|c|c|}
\hline \multicolumn{2}{|c|}{ Penetration } \\
\hline Ring & Depth (inches) \\
\hline Inner & 4.0 \\
\hline Outer & 3.0 \\
\hline \multicolumn{2}{|c|}{ Constant water level } \\
\hline Ring & Depth (inches) \\
\hline Inner & 2.25 \\
\hline Outer & 2.25 \\
\hline
\end{tabular}

\begin{tabular}{cc}
\hline \multicolumn{2}{c}{ Water temperature } \\
\hline Temperature (degrees Celsius) & Time \\
\hline 18.0 & $08: 55$ \\
21.0 & $11: 00$ \\
24.0 & $12: 32$ \\
\hline \multicolumn{2}{c}{ Soil temperature } \\
\hline Temperature (degrees Celsius) & Depth (inches) \\
\hline 19.5 & 4.5 \\
\hline
\end{tabular}

Comments: Inner ring initial fill depth 3 inches. Flow interrupted 11:00-11:15. 
Appendix 2-7. Infiltration data for site BR1.

[hrs, hours; min, minutes; mL, milliliters; cm/hr, centimeters per hour; --, no data]

\begin{tabular}{|c|c|c|c|c|c|c|c|}
\hline \multicolumn{2}{|c|}{ Time } & \multirow[b]{2}{*}{ Tube (units) } & \multirow[b]{2}{*}{ Time } & \multicolumn{2}{|c|}{ Time } & \multicolumn{2}{|c|}{ Incremental } \\
\hline hrs & $\min$ & & & Interval (hrs) & Elapsed (hrs) & Volume (mL) & Velocity $(\mathrm{cm} / \mathrm{hr})$ \\
\hline 11 & 08 & 0.20 & 11.133 & -- & -- & -- & -- \\
\hline 11 & 09 & 0.20 & 11.150 & 0.017 & 0.017 & -- & -- \\
\hline 11 & 10 & 0.20 & 11.167 & .017 & .033 & -- & -- \\
\hline 11 & 11 & 0.30 & 11.183 & .017 & .050 & 250 & 5.1 \\
\hline 11 & 12 & 0.60 & 11.200 & .017 & .067 & 750 & 15.2 \\
\hline 11 & 13 & 1.00 & 11.217 & .017 & .083 & 1,000 & 20.3 \\
\hline 11 & 14 & 1.40 & 11.233 & .017 & .100 & 1,000 & 20.3 \\
\hline 11 & 15 & 1.80 & 11.250 & .017 & .117 & 1,000 & 20.3 \\
\hline 11 & 20 & 3.90 & 11.333 & .083 & .200 & 5,250 & 21.3 \\
\hline 11 & 25 & 6.00 & 11.417 & .083 & .283 & 5,250 & 21.3 \\
\hline 11 & 32 & 9.10 & 11.533 & .117 & .400 & 7,750 & 22.5 \\
\hline 11 & 35 & 10.50 & 11.583 & .050 & .450 & 3,500 & 23.7 \\
\hline 11 & 40 & 12.80 & 11.667 & .083 & .533 & 5,750 & 23.4 \\
\hline 11 & 50 & 17.60 & 11.833 & .167 & .700 & 12,000 & 24.4 \\
\hline 12 & 00 & 22.30 & 12.000 & .167 & .867 & 11,750 & 23.9 \\
\hline 12 & 15 & 29.70 & 12.250 & .250 & 1.117 & 18,500 & 25.0 \\
\hline 12 & 30 & 36.90 & 12.500 & .250 & 1.367 & 18,000 & 24.4 \\
\hline 12 & 45 & 44.30 & 12.750 & .250 & 1.617 & 18,500 & 25.0 \\
\hline 12 & 50 & 46.80 & 12.833 & .083 & 1.700 & 6,250 & 25.4 \\
\hline 12 & 55 & 49.10 & 12.917 & .083 & 1.783 & 5,750 & 23.4 \\
\hline
\end{tabular}

\begin{tabular}{|c|c|}
\hline \multicolumn{2}{|c|}{ Penetration } \\
\hline Ring & Depth (inches) \\
\hline Inner & 3.5 \\
\hline Outer & 2.5 \\
\hline \multicolumn{2}{|c|}{ Constant water level } \\
\hline Ring & Depth (inches) \\
\hline Inner & 2.75 \\
\hline Outer & 2.75 \\
\hline
\end{tabular}

\begin{tabular}{cc}
\hline \multicolumn{2}{c}{ Water temperature } \\
\hline Temperature (degrees Celsius) & Time \\
\hline 12.5 & $11: 20$ \\
13.0 & $12: 15$ \\
14.5 & $12: 45$ \\
\hline \multicolumn{2}{c}{ Soil temperature } \\
\hline Temperature (degrees Celsius) & Depth (inches) \\
\hline 14.0 & 4.5 \\
\hline
\end{tabular}

Comments: Inner ring initial fill depth 3 inches. Light rain/drizzle. 
Appendix 2-8. Infiltration data for site BR2.

[hrs, hours; min, minutes; $\mathrm{mL}$, milliliters; $\mathrm{cm} / \mathrm{hr}$, centimeters per hour; --, no data]

\begin{tabular}{|c|c|c|c|c|c|c|c|}
\hline \multicolumn{2}{|c|}{ Time } & \multirow[b]{2}{*}{ Tube (units) } & \multirow[b]{2}{*}{ Time } & \multicolumn{2}{|c|}{ Time } & \multicolumn{2}{|c|}{ Incremental } \\
\hline hrs & $\min$ & & & Interval (hrs) & Elapsed (hrs) & Volume (mL) & Velocity $(\mathrm{cm} / \mathrm{hr})$ \\
\hline 8 & 19 & 0.40 & 8.317 & -- & -- & -- & -- \\
\hline 8 & 20 & .40 & 8.333 & 0.017 & 0.017 & -- & -- \\
\hline 8 & 21 & .40 & 8.350 & .017 & .033 & -- & -- \\
\hline 8 & 22 & .40 & 8.367 & .017 & .050 & -- & -- \\
\hline 8 & 23 & .40 & 8.383 & .017 & .067 & -- & -- \\
\hline 8 & 24 & .40 & 8.400 & .017 & .083 & -- & -- \\
\hline 8 & 25 & .40 & 8.417 & .017 & .100 & -- & -- \\
\hline 8 & 26 & .40 & 8.433 & .017 & .117 & -- & -- \\
\hline 8 & 27 & .40 & 8.450 & .017 & .133 & -- & -- \\
\hline 8 & 28 & .40 & 8.467 & .017 & .150 & -- & -- \\
\hline 8 & 29 & .50 & 8.483 & .017 & .167 & 250 & 5.1 \\
\hline 8 & 30 & .60 & 8.500 & .017 & .183 & 250 & 5.1 \\
\hline 8 & 31 & .80 & 8.517 & .017 & .200 & 500 & 10.2 \\
\hline 8 & 32 & 1.00 & 8.533 & .017 & .217 & 500 & 10.2 \\
\hline 8 & 33 & 1.30 & 8.550 & .017 & .233 & 750 & 15.2 \\
\hline 8 & 34 & 1.50 & 8.567 & .017 & .250 & 500 & 10.2 \\
\hline 8 & 35 & 1.70 & 8.583 & .017 & .267 & 500 & 10.2 \\
\hline 8 & 40 & 2.80 & 8.667 & .083 & .350 & 2,750 & 11.2 \\
\hline 8 & 45 & 3.70 & 8.750 & .083 & .433 & 2,250 & 9.1 \\
\hline 8 & 50 & 4.90 & 8.833 & .083 & .517 & 3,000 & 12.2 \\
\hline 8 & 55 & 5.90 & 8.917 & .083 & .600 & 2,500 & 10.2 \\
\hline 9 & 00 & 7.00 & 9.000 & .083 & .683 & 2,750 & 11.2 \\
\hline 9 & 10 & 9.20 & 9.167 & .167 & .850 & 5,500 & 11.2 \\
\hline 9 & 20 & 11.40 & 9.333 & .167 & 1.017 & 5,500 & 11.2 \\
\hline 9 & 30 & 13.70 & 9.500 & .167 & 1.183 & 5,750 & 11.7 \\
\hline 9 & 45 & 17.00 & 9.750 & .250 & 1.433 & 8,250 & 11.2 \\
\hline 10 & 00 & 20.30 & 10.000 & .250 & 1.683 & 8,250 & 11.2 \\
\hline 10 & 15 & 23.90 & 10.250 & .250 & 1.933 & 8,999 & 12.2 \\
\hline 10 & 31 & 27.40 & 10.517 & .267 & 2.200 & 8,750 & 11.1 \\
\hline 10 & 45 & 30.80 & 10.750 & .233 & 2.433 & 8,500 & 12.3 \\
\hline
\end{tabular}

\begin{tabular}{|c|c|}
\hline \multicolumn{2}{|c|}{ Penetration } \\
\hline Ring & Depth (inches) \\
\hline Inner & 3.5 \\
\hline Outer & 2.5 \\
\hline \multicolumn{2}{|c|}{ Constant water level } \\
\hline Ring & Depth (inches) \\
\hline Inner & 2.75 \\
\hline Outer & 2.75 \\
\hline
\end{tabular}

\begin{tabular}{cc}
\hline \multicolumn{2}{c}{ Water temperature } \\
\hline Temperature (degrees Celsius) & Time \\
\hline 12.5 & $11: 20$ \\
13.0 & $12: 15$ \\
14.5 & $12: 45$ \\
\hline \multicolumn{2}{c}{ Soil temperature } \\
\hline Temperature (degrees Celsius) & Depth (inches) \\
\hline 14.0 & 4.5 \\
\hline
\end{tabular}

Comments: Inner ring initial fill depth 3 inches. 
Appendix 2-9. Infiltration data for site BR3.

[hrs, hours; min, minutes; $\mathrm{mL}$, milliliters; $\mathrm{cm} / \mathrm{hr}$, centimeters per hour; --, no data]

\begin{tabular}{|c|c|c|c|c|c|c|c|}
\hline \multicolumn{2}{|c|}{ Time } & \multirow[b]{2}{*}{ Tube (units) } & \multirow[b]{2}{*}{ Time } & \multicolumn{2}{|c|}{ Time } & \multicolumn{2}{|c|}{ Incremental } \\
\hline hrs & $\min$ & & & Interval (hrs) & Elapsed (hrs) & Volume (mL) & Velocity $(\mathrm{cm} / \mathrm{hr})$ \\
\hline 11 & 25 & -- & 11.417 & -- & -- & -- & -- \\
\hline 11 & 27 & 0.20 & 11.450 & 0.033 & 0.033 & 500 & 5.1 \\
\hline 11 & 28 & .40 & 11.467 & .017 & .050 & 500 & 10.2 \\
\hline 11 & 29 & .70 & 11.483 & .017 & .067 & 750 & 15.2 \\
\hline 11 & 30 & .90 & 11.500 & .017 & .083 & 500 & 10.2 \\
\hline 11 & 31 & 1.10 & 11.517 & .017 & .100 & 500 & 10.2 \\
\hline 11 & 32 & 1.30 & 11.533 & .017 & .117 & 500 & 10.2 \\
\hline 11 & 33 & 1.60 & 11.550 & .017 & .133 & 750 & 15.2 \\
\hline 11 & 34 & 1.80 & 11.567 & .017 & .150 & 500 & 10.2 \\
\hline 11 & 35 & 2.00 & 11.583 & .017 & .167 & 500 & 10.2 \\
\hline 11 & 40 & 3.30 & 11.667 & .083 & .250 & 3,250 & 13.2 \\
\hline 11 & 45 & 4.30 & 11.750 & .083 & .333 & 2,500 & 10.2 \\
\hline 11 & 50 & 5.30 & 11.833 & .083 & .417 & 2,500 & 10.2 \\
\hline 11 & 55 & 6.40 & 11.917 & .083 & .500 & 2,750 & 11.2 \\
\hline 12 & 00 & 7.40 & 12.000 & .083 & .583 & 2,500 & 10.2 \\
\hline 12 & 15 & 10.80 & 12.250 & .250 & .833 & 8,500 & 11.5 \\
\hline 12 & 30 & 14.20 & 12.500 & .250 & 1.083 & 8,500 & 11.5 \\
\hline 12 & 45 & 17.60 & 12.750 & .250 & 1.333 & 8,500 & 11.5 \\
\hline 13 & 00 & 21.10 & 13.000 & .250 & 1.583 & 8,750 & 11.8 \\
\hline 13 & 15 & 24.60 & 13.250 & .250 & 1.833 & 8,750 & 11.8 \\
\hline 13 & 30 & 28.30 & 13.500 & .250 & 2.083 & 9,250 & 12.5 \\
\hline 13 & 45 & 31.90 & 13.750 & .250 & 2.333 & 8,999 & 12.2 \\
\hline 14 & 00 & 35.60 & 14.000 & .250 & 2.583 & 9,250 & 12.5 \\
\hline 14 & 15 & 39.30 & 14.250 & .250 & 2.833 & 9,249 & 12.5 \\
\hline 14 & 30 & 42.90 & 14.500 & .250 & 3.083 & 9,000 & 12.2 \\
\hline 14 & 40 & 45.40 & 14.667 & .167 & 3.250 & 6,250 & 12.7 \\
\hline
\end{tabular}

\begin{tabular}{|c|c|}
\hline \multicolumn{2}{|c|}{ Penetration } \\
\hline Ring & Depth (inches) \\
\hline Inner & 4.2 \\
\hline Outer & 3.3 \\
\hline \multicolumn{2}{|c|}{ Constant water level } \\
\hline Ring & Depth (inches) \\
\hline Inner & 2.25 \\
\hline Outer & 2.25 \\
\hline
\end{tabular}

\begin{tabular}{cc}
\hline \multicolumn{2}{c}{ Water temperature } \\
\hline Temperature (degrees Celsius) & Time \\
\hline 12.0 & $11: 35$ \\
16.0 & $12: 00$ \\
20.0 & $14: 00$ \\
\hline \multicolumn{2}{c}{ Soil temperature } \\
\hline Temperature (degrees Celsius) & Depth (inches) \\
\hline 13.0 & 4.5 \\
\hline
\end{tabular}

Comments: Inner ring initial fill depth 3 inches. 
Appendix 2-10. Infiltration data for site AFB1.

[hrs, hours; min, minutes; $\mathrm{mL}$, milliliters; $\mathrm{cm} / \mathrm{hr}$, centimeters per hour; --, no data]

\begin{tabular}{|c|c|c|c|c|c|c|c|}
\hline \multicolumn{2}{|c|}{ Time } & \multirow[b]{2}{*}{ Tube (units) } & \multirow[b]{2}{*}{ Time } & \multicolumn{2}{|c|}{ Time } & \multicolumn{2}{|c|}{ Incremental } \\
\hline hrs & $\min$ & & & Interval (hrs) & Elapsed (hrs) & Volume (mL) & Velocity $(\mathrm{cm} / \mathrm{hr})$ \\
\hline 8 & 49 & -- & 8.817 & -- & -- & -- & -- \\
\hline 8 & 50 & 0.20 & 8.833 & 0.017 & 0.017 & 500 & 10.2 \\
\hline 8 & 51 & 1.40 & 8.850 & .017 & .033 & 3,000 & 60.9 \\
\hline 8 & 52 & 2.70 & 8.867 & .017 & .050 & 3,250 & 66.0 \\
\hline 8 & 53 & 3.90 & 8.883 & .017 & .067 & 3,000 & 60.9 \\
\hline 8 & 54 & 5.00 & 8.900 & .017 & .083 & 2,750 & 55.8 \\
\hline 8 & 55 & 5.90 & 8.917 & .017 & .100 & 2,250 & 45.7 \\
\hline 8 & 56 & 6.90 & 8.933 & .017 & .117 & 2,500 & 50.8 \\
\hline 8 & 57 & 7.70 & 8.950 & .017 & .133 & 2,000 & 40.6 \\
\hline 8 & 58 & 8.60 & 8.967 & .017 & .150 & 2,250 & 45.7 \\
\hline 8 & 59 & 9.30 & 8.983 & .017 & .167 & 1,750 & 35.5 \\
\hline 9 & 00 & 10.10 & 9.000 & .017 & .183 & 2,000 & 40.6 \\
\hline 9 & 01 & 10.80 & 9.017 & .017 & .200 & 1,750 & 35.5 \\
\hline 9 & 02 & 11.50 & 9.033 & .017 & .217 & 1,750 & 35.5 \\
\hline 9 & 03 & 12.10 & 9.050 & .017 & .233 & 1,500 & 30.5 \\
\hline 9 & 04 & 12.70 & 9.067 & .017 & .250 & 1,500 & 30.5 \\
\hline 9 & 05 & 13.30 & 9.083 & .017 & .267 & 1,500 & 30.5 \\
\hline 9 & 06 & 14.00 & 9.100 & .017 & .283 & 1,750 & 35.5 \\
\hline 9 & 07 & 14.50 & 9.117 & .017 & .300 & 1,250 & 25.4 \\
\hline 9 & 08 & 15.10 & 9.133 & .017 & .317 & 1,500 & 30.5 \\
\hline 9 & 09 & 15.70 & 9.150 & .017 & .333 & 1,500 & 30.5 \\
\hline 9 & 10 & 16.20 & 9.167 & .017 & .350 & 1,250 & 25.4 \\
\hline 9 & 15 & 18.50 & 9.250 & .083 & .433 & 5,750 & 23.4 \\
\hline 9 & 20 & 20.60 & 9.333 & .083 & .517 & 5,250 & 21.3 \\
\hline 9 & 25 & 22.50 & 9.417 & .083 & .600 & 4,750 & 19.3 \\
\hline 9 & 30 & 24.20 & 9.500 & .083 & .683 & 4,250 & 17.3 \\
\hline 9 & 36 & 26.10 & 9.600 & .100 & .783 & 4,750 & 16.1 \\
\hline 9 & 40 & 27.20 & 9.667 & .067 & .850 & 2,749 & 14.0 \\
\hline 9 & 45 & 28.50 & 9.750 & .083 & .933 & 3,250 & 13.2 \\
\hline 9 & 50 & 29.70 & 9.833 & .083 & 1.017 & 3,000 & 12.2 \\
\hline 9 & 55 & 30.90 & 9.917 & .083 & 1.100 & 3,000 & 12.2 \\
\hline 10 & 00 & 32.10 & 10.000 & .083 & 1.183 & 3,000 & 12.2 \\
\hline 10 & 05 & 33.20 & 10.083 & .083 & 1.267 & 2,750 & 11.2 \\
\hline 10 & 10 & 34.30 & 10.167 & .083 & 1.350 & 2,749 & 11.2 \\
\hline 10 & 15 & 35.40 & 10.250 & .083 & 1.433 & 2,750 & 11.2 \\
\hline 10 & 20 & 36.40 & 10.333 & .083 & 1.517 & 2,500 & 10.2 \\
\hline 10 & 25 & 37.30 & 10.417 & .083 & 1.600 & 2,250 & 9.1 \\
\hline 10 & 30 & 38.30 & 10.500 & .083 & 1.683 & 2,500 & 10.2 \\
\hline 10 & 35 & 39.30 & 10.583 & .083 & 1.767 & 2,500 & 10.2 \\
\hline
\end{tabular}


Appendix 2-10. Infiltration data for site AFB1.-Continued

\begin{tabular}{|c|c|c|c|c|c|c|c|}
\hline \multicolumn{2}{|c|}{ Time } & \multirow[b]{2}{*}{ Tube (units) } & \multirow[b]{2}{*}{ Time } & \multicolumn{2}{|c|}{ Time } & \multicolumn{2}{|c|}{ Incremental } \\
\hline hrs & $\min$ & & & Interval (hrs) & Elapsed (hrs) & Volume (mL) & Velocity (cm/hr) \\
\hline 10 & 40 & 40.20 & 10.667 & 0.083 & 1.850 & 2,250 & 9.1 \\
\hline 10 & 45 & 41.00 & 10.750 & .083 & 1.933 & 1,999 & 8.1 \\
\hline 10 & 50 & 41.90 & 10.833 & .083 & 2.017 & 2,250 & 9.1 \\
\hline 10 & 55 & 42.70 & 10.917 & .083 & 2.100 & 2,000 & 8.1 \\
\hline 11 & 00 & 43.40 & 11.000 & .083 & 2.183 & 1,749 & 7.1 \\
\hline 11 & 05 & 44.00 & 11.083 & .083 & 2.267 & 1,500 & 6.1 \\
\hline 11 & 10 & 44.60 & 11.167 & .083 & 2.350 & 1,500 & 6.1 \\
\hline
\end{tabular}

\begin{tabular}{|c|c|}
\hline \multicolumn{2}{|c|}{ Penetration } \\
\hline Ring & Depth (inches) \\
\hline Inner & 4.3 \\
\hline Outer & 2.5 \\
\hline \multicolumn{2}{|c|}{ Constant water level } \\
\hline Ring & Depth (inches) \\
\hline Inner & 3.25 \\
\hline Outer & 3.25 \\
\hline
\end{tabular}

\begin{tabular}{cc}
\hline \multicolumn{2}{c}{ Water temperature } \\
\hline Temperature (degrees Celsius) & Time \\
\hline 16.0 & $09: 01$ \\
18.0 & $09: 55$ \\
21.0 & $11: 00$ \\
\hline \multicolumn{2}{c}{ Soil temperature } \\
\hline Temperature (degrees Celsius) & Depth (inches) \\
\hline 13.5 & 4.5 \\
\hline
\end{tabular}

Comments: Inner ring initial fill depth 3.5 inches. 
Appendix 2-11. Infiltration data for site AFB2.

[hrs, hours; min, minutes; $\mathrm{mL}$, milliliters; $\mathrm{cm} / \mathrm{hr}$, centimeters per hour; --, no data]

\begin{tabular}{|c|c|c|c|c|c|c|c|}
\hline \multicolumn{2}{|c|}{ Time } & \multirow[b]{2}{*}{ Tube (units) } & \multirow[b]{2}{*}{ Time } & \multicolumn{2}{|c|}{ Time } & \multicolumn{2}{|c|}{ Incremental } \\
\hline hrs & $\min$ & & & Interval (hrs) & Elapsed (hrs) & Volume (mL) & Velocity $(\mathrm{cm} / \mathrm{hr})$ \\
\hline 11 & 51 & -- & 11.850 & -- & -- & -- & -- \\
\hline 11 & 52 & -- & 11.867 & 0.017 & 0.017 & -- & -- \\
\hline 11 & 53 & -- & 11.883 & .017 & .033 & -- & -- \\
\hline 11 & 54 & 0.10 & 11.900 & .017 & .050 & 250 & 5.1 \\
\hline 11 & 55 & .50 & 11.917 & .017 & .067 & 1,000 & 20.3 \\
\hline 11 & 56 & 1.10 & 11.933 & .017 & .083 & 1,500 & 30.5 \\
\hline 11 & 57 & 1.80 & 11.950 & .017 & .100 & 1,750 & 35.5 \\
\hline 11 & 58 & 2.50 & 11.967 & .017 & .117 & 1,750 & 35.5 \\
\hline 11 & 59 & 3.20 & 11.983 & .017 & .133 & 1,750 & 35.5 \\
\hline 12 & 00 & 3.90 & 12.000 & .017 & .150 & 1,750 & 35.5 \\
\hline 12 & 05 & 7.10 & 12.083 & .083 & .233 & 8,000 & 32.5 \\
\hline 12 & 10 & 10.30 & 12.167 & .083 & .317 & 8,000 & 32.5 \\
\hline 12 & 15 & 13.50 & 12.250 & .083 & .400 & 8,000 & 32.5 \\
\hline 12 & 20 & 16.40 & 12.333 & .083 & .483 & 7,250 & 29.4 \\
\hline 12 & 25 & 19.30 & 12.417 & .083 & .567 & 7,250 & 29.4 \\
\hline 12 & 30 & 21.90 & 12.500 & .083 & .650 & 6,499 & 26.4 \\
\hline 12 & 35 & 24.30 & 12.583 & .083 & .733 & 6,000 & 24.4 \\
\hline 12 & 40 & 26.60 & 12.667 & .083 & .817 & 5,750 & 23.4 \\
\hline 12 & 45 & 28.70 & 12.750 & .083 & .900 & 5,249 & 21.3 \\
\hline 12 & 50 & 30.70 & 12.833 & .083 & .983 & 5,000 & 20.3 \\
\hline 12 & 55 & 32.70 & 12.917 & .083 & 1.067 & 5,000 & 20.3 \\
\hline 13 & 00 & 34.40 & 13.000 & .083 & 1.150 & 4,249 & 17.3 \\
\hline 13 & 05 & 36.10 & 13.083 & .083 & 1.233 & 4,250 & 17.3 \\
\hline 13 & 10 & 37.80 & 13.167 & .083 & 1.317 & 4,249 & 17.3 \\
\hline 13 & 15 & 39.30 & 13.250 & .083 & 1.400 & 3,750 & 15.2 \\
\hline 13 & 20 & 40.60 & 13.333 & .083 & 1.483 & 3,250 & 13.2 \\
\hline 13 & 25 & 43.10 & 13.417 & .083 & 1.567 & 6,250 & 25.4 \\
\hline 13 & 30 & 45.10 & 13.500 & .083 & 1.650 & 5,000 & 20.3 \\
\hline 13 & 31 & 45.40 & 13.517 & .017 & 1.667 & 749 & 15.2 \\
\hline 13 & 32 & 45.70 & 13.533 & .017 & 1.683 & 750 & 15.2 \\
\hline 13 & 33 & 46.00 & 13.550 & .017 & 1.700 & 749 & 15.2 \\
\hline 13 & 34 & 46.30 & 13.567 & .017 & 1.717 & 749 & 15.2 \\
\hline 13 & 36 & 46.90 & 13.600 & .033 & 1.750 & 1,500 & 15.2 \\
\hline 13 & 38 & 47.30 & 13.633 & .033 & 1.783 & 999 & 10.1 \\
\hline 13 & 40 & 47.70 & 13.667 & .033 & 1.817 & 1,000 & 10.2 \\
\hline
\end{tabular}


Appendix 2-11. Infiltration data for site AFB2.-Continued

\begin{tabular}{|c|c|}
\hline \multicolumn{2}{|c|}{ Penetration } \\
\hline Ring & Depth (inches) \\
\hline Inner & 4.5 \\
\hline Outer & 3.0 \\
\hline \multicolumn{2}{|c|}{ Constant water level } \\
\hline Ring & Depth (inches) \\
\hline Inner & 2.25 \\
\hline Outer & 2.25 \\
\hline
\end{tabular}

\begin{tabular}{cc}
\hline \multicolumn{2}{c}{ Water temperature } \\
\hline Temperature (degrees Celsius) & Time \\
\hline 22.0 & $12: 00$ \\
25.0 & $12: 45$ \\
26.0 & $13: 34$ \\
\hline \multicolumn{2}{c}{ Soil temperature } \\
\hline Temperature (degrees Celsius) & Depth (inches) \\
\hline 15.0 & 4.5 \\
\hline
\end{tabular}

Comments: Inner ring initial fill depth 3.5 inches. Flow interrupted 13:20. 


\section{Soils Infiltration Data for Selected Wyoming Watersheds, 1998-99}

Appendix 2-12. Infiltration data for site GC1.

[hrs, hours; min, minutes; $\mathrm{mL}$, milliliters; $\mathrm{cm} / \mathrm{hr}$, centimeters per hour; --, no data; NA, not applicable]

\begin{tabular}{|c|c|c|c|c|c|c|c|}
\hline \multicolumn{2}{|c|}{ Time } & \multirow[b]{2}{*}{ Tube (units) } & \multirow[b]{2}{*}{ Time } & \multicolumn{2}{|c|}{ Time } & \multicolumn{2}{|c|}{ Incremental } \\
\hline hrs & $\min$ & & & Interval (hrs) & Elapsed (hrs) & Volume (mL) & Velocity $(\mathrm{cm} / \mathrm{hr})$ \\
\hline 13 & 45 & 22.50 & 13.750 & -- & -- & -- & -- \\
\hline 13 & 46 & 24.50 & 13.767 & 0.017 & 0.017 & 5,000 & 101.5 \\
\hline 13 & 47 & 26.00 & 13.783 & .017 & .033 & 3,750 & 76.1 \\
\hline 13 & 48 & 26.80 & 13.800 & .017 & .050 & 2,000 & 40.6 \\
\hline 13 & 49 & 27.40 & 13.817 & .017 & .067 & 1,499 & 30.4 \\
\hline 13 & 50 & 27.90 & 13.833 & .017 & .083 & 1,250 & 25.4 \\
\hline 13 & 51 & 28.30 & 13.850 & .017 & .100 & 1,000 & 20.3 \\
\hline 13 & 52 & 28.60 & 13.867 & .017 & .117 & 750 & 15.2 \\
\hline 13 & 53 & 29.00 & 13.883 & .017 & .133 & 999 & 20.3 \\
\hline 13 & 54 & 29.30 & 13.900 & .017 & .150 & 750 & 15.2 \\
\hline 13 & 55 & 29.60 & 13.917 & .017 & .167 & 750 & 15.2 \\
\hline 13 & 56 & 30.00 & 13.933 & .017 & .183 & 999 & 20.3 \\
\hline 13 & 57 & 30.30 & 13.950 & .017 & .200 & 750 & 15.2 \\
\hline 13 & 58 & 30.50 & 13.967 & .017 & .217 & 499 & 10.1 \\
\hline 13 & 59 & 30.60 & 13.983 & .017 & .233 & 250 & 5.1 \\
\hline 14 & 00 & 30.80 & 14.000 & .017 & .250 & 499 & 10.1 \\
\hline 14 & 05 & 32.00 & 14.083 & .083 & .333 & 3,000 & 12.2 \\
\hline 14 & 10 & 33.00 & 14.167 & .083 & .417 & 2,500 & 10.2 \\
\hline
\end{tabular}

\begin{tabular}{|c|c|}
\hline \multicolumn{2}{|c|}{ Penetration } \\
\hline Ring & Depth (inches) \\
\hline Inner & 2.0 \\
\hline Outer & 2.0 \\
\hline \multicolumn{2}{|c|}{ Constant water level } \\
\hline Ring & Depth (feet) \\
\hline Inner & 0.50 \\
\hline Outer & 0.50 \\
\hline
\end{tabular}

\begin{tabular}{cc}
\hline \multicolumn{2}{c}{ Water temperature } \\
\hline Temperature (degrees Celsius) & Time \\
\hline 20.0 & $13: 48$ \\
20.0 & $13: 59$ \\
\multicolumn{2}{c}{ Soil temperature } \\
\hline Temperature (degrees Celsius) & Depth (inches) \\
\hline NA & NA \\
\hline
\end{tabular}

Comments: No evidence of rings leaking. 
Appendix 2-13. Infiltration data for site GC2.

[hrs, hours; min, minutes; $\mathrm{mL}$, milliliters; $\mathrm{cm} / \mathrm{hr}$, centimeters per hour; --, no data]

\begin{tabular}{|c|c|c|c|c|c|c|c|}
\hline \multicolumn{2}{|c|}{ Time } & \multirow[b]{2}{*}{ Tube (units) } & \multirow[b]{2}{*}{ Time } & \multicolumn{2}{|c|}{ Time } & \multicolumn{2}{|c|}{ Incremental } \\
\hline hrs & $\min$ & & & Interval (hrs) & Elapsed (hrs) & Volume (mL) & Velocity $(\mathrm{cm} / \mathrm{hr})$ \\
\hline 9 & 52 & 2.20 & 9.867 & -- & -- & -- & -- \\
\hline 9 & 54 & 2.40 & 9.900 & 0.033 & 0.033 & 499 & 5.1 \\
\hline 9 & 56 & 2.90 & 9.933 & .033 & .067 & 1,250 & 12.7 \\
\hline 9 & 58 & 3.40 & 9.967 & .033 & .100 & 1,250 & 12.7 \\
\hline 10 & 00 & 3.90 & 10.000 & .033 & .133 & 1,250 & 12.7 \\
\hline 10 & 02 & 4.60 & 10.033 & .033 & .167 & 1,750 & 17.8 \\
\hline 10 & 04 & 5.20 & 10.067 & .033 & .200 & 1,500 & 15.2 \\
\hline 10 & 06 & 5.90 & 10.100 & .033 & .233 & 1,750 & 17.8 \\
\hline 10 & 08 & 7.00 & 10.133 & .033 & .267 & 2,750 & 27.9 \\
\hline 10 & 10 & 8.10 & 10.167 & .033 & .300 & 2,750 & 27.9 \\
\hline 10 & 15 & 10.80 & 10.250 & .083 & .383 & 6,750 & 27.4 \\
\hline 10 & 20 & 13.20 & 10.333 & .083 & .467 & 6,000 & 24.4 \\
\hline 10 & 25 & 14.10 & 10.417 & .083 & .550 & 2,250 & 9.1 \\
\hline 10 & 30 & 14.80 & 10.500 & .083 & 633 & 1,750 & 7.1 \\
\hline 10 & 32 & 15.20 & 10.533 & .033 & 0.667 & 999 & 10.1 \\
\hline 10 & 34 & 15.30 & 10.567 & .033 & 0.700 & 250 & 2.5 \\
\hline 10 & 36 & 15.60 & 10.600 & .033 & 0.733 & 749 & 7.6 \\
\hline 10 & 38 & 15.90 & 10.633 & .033 & 0.767 & 750 & 7.6 \\
\hline 10 & 40 & 16.60 & 10.667 & .033 & 0.800 & 1,750 & 17.8 \\
\hline 10 & 42 & 17.20 & 10.700 & .033 & 0.833 & 1,499 & 15.2 \\
\hline 10 & 44 & 17.90 & 10.733 & .033 & 0.867 & 1,750 & 17.8 \\
\hline 10 & 46 & 18.30 & 10.767 & .033 & 0.900 & 1,000 & 10.2 \\
\hline 10 & 48 & 18.70 & 10.800 & .033 & 0.933 & 999 & 10.1 \\
\hline 10 & 50 & 20.60 & 10.833 & .033 & 0.967 & 4,750 & 48.2 \\
\hline 10 & 52 & 24.20 & 10.867 & .033 & 1.000 & 8,999 & 91.4 \\
\hline 10 & 54 & 27.60 & 10.900 & .033 & 1.033 & 8,500 & 86.3 \\
\hline 10 & 56 & 30.80 & 10.933 & .033 & 1.067 & 8,000 & 81.2 \\
\hline 10 & 58 & 33.70 & 10.967 & .033 & 1.100 & 7,250 & 73.6 \\
\hline 11 & 00 & 36.30 & 11.000 & .033 & 1.133 & 6,499 & 66.0 \\
\hline 11 & 02 & 38.60 & 11.033 & .033 & 1.167 & 5,750 & 58.4 \\
\hline 11 & 04 & 40.60 & 11.067 & .033 & 1.200 & 5,000 & 50.8 \\
\hline 11 & 06 & 42.50 & 11.100 & .033 & 1.233 & 4,750 & 48.2 \\
\hline 11 & 08 & 43.70 & 11.133 & .033 & 1.267 & 3,000 & 30.5 \\
\hline 11 & 10 & 43.70 & 11.167 & .033 & 1.300 & -- & -- \\
\hline
\end{tabular}


Appendix 2-13. Infiltration data for site GC2.-Continued

\begin{tabular}{|c|c|}
\hline \multicolumn{2}{|c|}{ Penetration } \\
\hline Ring & Depth (inches) \\
\hline Inner & 2.0 \\
\hline Outer & 2.0 \\
\hline \multicolumn{2}{|c|}{ Constant water level } \\
\hline Ring & Depth (feet) \\
\hline Inner & 0.30 \\
\hline Outer & 0.30 \\
\hline
\end{tabular}

\begin{tabular}{cc}
\hline \multicolumn{2}{c}{ Water temperature } \\
\hline Temperature (degrees Celsius) & Time \\
\hline 15.0 & $09: 54$ \\
15.0 & $10: 32$ \\
16.5 & $11: 00$ \\
\hline \multicolumn{2}{c}{ Soil temperature } \\
\hline Temperature (degrees Celsius) & Depth (feet) \\
\hline 14.0 & 0.4 \\
\hline
\end{tabular}

Comments: Inner-ring water level varied. Inner ring leak 10:50. Debris in site tube. 
Appendix 2-14. Infiltration data for site GC3.

[hrs, hours; min, minutes; mL, milliliters; cm/hr, centimeters per hour; --, no data]

\begin{tabular}{|c|c|c|c|c|c|c|c|}
\hline \multicolumn{2}{|c|}{ Time } & \multirow[b]{2}{*}{ Tube (units) } & \multirow[b]{2}{*}{ Time } & \multicolumn{2}{|c|}{ Time } & \multicolumn{2}{|c|}{ Incremental } \\
\hline hrs & $\min$ & & & Interval (hrs) & Elapsed (hrs) & Volume (mL) & Velocity $(\mathrm{cm} / \mathrm{hr})$ \\
\hline 12 & 09 & 0.70 & 12.150 & -- & -- & -- & -- \\
\hline 12 & 14 & 4.30 & 12.233 & 0.083 & 0.083 & 9,000 & 36.5 \\
\hline 12 & 15 & 6.30 & 12.250 & .017 & .100 & 5,000 & 101.5 \\
\hline 12 & 16 & 7.30 & 12.267 & .017 & .117 & 2,500 & 50.8 \\
\hline 12 & 17 & 8.30 & 12.283 & .017 & .133 & 2,500 & 50.8 \\
\hline 12 & 18 & 9.30 & 12.300 & .017 & .150 & 2,500 & 50.8 \\
\hline 12 & 19 & 10.10 & 12.317 & .017 & .167 & 2,000 & 40.6 \\
\hline 12 & 20 & 10.90 & 12.333 & .017 & .183 & 2,000 & 40.6 \\
\hline 12 & 21 & 11.70 & 12.350 & .017 & .200 & 2,000 & 40.6 \\
\hline 12 & 23 & 13.20 & 12.383 & .033 & .233 & 3,750 & 38.1 \\
\hline 12 & 25 & 14.70 & 12.417 & .033 & .267 & 3,750 & 38.1 \\
\hline 12 & 27 & 16.20 & 12.450 & .033 & .300 & 3,750 & 38.1 \\
\hline 12 & 29 & 17.40 & 12.483 & .033 & .333 & 3,000 & 30.5 \\
\hline 12 & 31 & 18.60 & 12.517 & .033 & .367 & 3,000 & 30.5 \\
\hline 12 & 33 & 19.80 & 12.550 & .033 & .400 & 3,000 & 30.5 \\
\hline 12 & 36 & 21.50 & 12.600 & .050 & .450 & 4,250 & 28.8 \\
\hline 12 & 39 & 23.20 & 12.650 & .050 & .500 & 4,250 & 28.8 \\
\hline 12 & 42 & 24.60 & 12.700 & .050 & .550 & 3,500 & 23.7 \\
\hline 12 & 45 & 26.10 & 12.750 & .050 & .600 & 3,750 & 25.4 \\
\hline 12 & 48 & 27.60 & 12.800 & .050 & .650 & 3,750 & 25.4 \\
\hline 12 & 51 & 29.00 & 12.850 & .050 & .700 & 3,500 & 23.7 \\
\hline 12 & 54 & 30.20 & 12.900 & .050 & .750 & 3,000 & 20.3 \\
\hline 12 & 58 & 31.90 & 12.967 & .067 & .817 & 4,250 & 21.6 \\
\hline 13 & 02 & 33.50 & 13.033 & .067 & .883 & 4,000 & 20.3 \\
\hline 13 & 06 & 35.00 & 13.100 & .067 & .950 & 3,750 & 19.0 \\
\hline 13 & 10 & 36.50 & 13.167 & .067 & 1.017 & 3,750 & 19.0 \\
\hline 13 & 15 & 38.20 & 13.250 & .083 & 1.100 & 4,250 & 17.3 \\
\hline 13 & 20 & 39.80 & 13.333 & .083 & 1.183 & 3,999 & 16.2 \\
\hline 13 & 25 & 41.50 & 13.417 & .083 & 1.267 & 4,250 & 17.3 \\
\hline 13 & 30 & 43.20 & 13.500 & .083 & 1.350 & 4,250 & 17.3 \\
\hline
\end{tabular}

\begin{tabular}{|c|c|}
\hline \multicolumn{2}{|c|}{ Penetration } \\
\hline Ring & Depth (inches) \\
\hline Inner & 2.3 \\
\hline Outer & 2.3 \\
\hline \multicolumn{2}{|c|}{ Constant water level } \\
\hline Ring & Depth (feet) \\
\hline Inner & 0.25 \\
\hline Outer & 0.25 \\
\hline
\end{tabular}

\begin{tabular}{cc}
\hline \multicolumn{2}{c}{ Water temperature } \\
\hline Temperature (degrees Celsius) & Time \\
\hline 18.0 & $12: 14$ \\
21.5 & $12: 23$ \\
26.5 & $13: 25$ \\
\hline \multicolumn{2}{c}{ Soil temperature } \\
\hline Temperature (degrees Celsius) & Depth (feet) \\
\hline 14.0 & 0.4 \\
\hline
\end{tabular}

Comments: No evidence of rings leaking. Debris in site tube initially. 


\section{Soils Infiltration Data for Selected Wyoming Watersheds, 1998-99}

Appendix 2-15. Infiltration data for site LG1.

[hrs, hours; min, minutes; $\mathrm{mL}$, milliliters; $\mathrm{cm} / \mathrm{hr}$, centimeters per hour; --, no data]

\begin{tabular}{|c|c|c|c|c|c|c|c|}
\hline \multicolumn{2}{|c|}{ Time } & \multirow[b]{2}{*}{ Tube (units) } & \multirow[b]{2}{*}{ Time } & \multicolumn{2}{|c|}{ Time } & \multicolumn{2}{|c|}{ Incremental } \\
\hline hrs & $\min$ & & & Interval (hrs) & Elapsed (hrs) & Volume (mL) & Velocity $(\mathrm{cm} / \mathrm{hr})$ \\
\hline 15 & 42 & 2.60 & 15.700 & -- & -- & -- & -- \\
\hline 15 & 43 & 3.50 & 15.717 & 0.017 & 0.017 & 2,250 & 45.7 \\
\hline 15 & 44 & 4.70 & 15.733 & .017 & .033 & 3,000 & 60.9 \\
\hline 15 & 45 & 6.20 & 15.750 & .017 & .050 & 3,750 & 76.1 \\
\hline 15 & 46 & 7.40 & 15.767 & .017 & .067 & 3,000 & 60.9 \\
\hline 15 & 47 & 8.50 & 15.783 & .017 & .083 & 2,750 & 55.8 \\
\hline 15 & 48 & 9.50 & 15.800 & .017 & .100 & 2,500 & 50.8 \\
\hline 15 & 49 & 10.60 & 15.817 & .017 & .117 & 2,750 & 55.8 \\
\hline 15 & 50 & 11.60 & 15.833 & .017 & .133 & 2,500 & 50.8 \\
\hline 15 & 51 & 12.70 & 15.850 & .017 & .150 & 2,750 & 55.8 \\
\hline 15 & 52 & 13.70 & 15.867 & .017 & .167 & 2,500 & 50.8 \\
\hline 15 & 53 & 14.60 & 15.883 & .017 & .183 & 2,250 & 45.7 \\
\hline 15 & 54 & 15.60 & 15.900 & .017 & .200 & 2,500 & 50.8 \\
\hline 15 & 55 & 16.60 & 15.917 & .017 & .217 & 2,500 & 50.8 \\
\hline 15 & 56 & 17.60 & 15.933 & .017 & .233 & 2,500 & 50.8 \\
\hline 15 & 57 & 18.60 & 15.950 & .017 & .250 & 2,500 & 50.8 \\
\hline 15 & 58 & 19.60 & 15.967 & .017 & .267 & 2,500 & 50.8 \\
\hline 15 & 59 & 20.50 & 15.983 & .017 & .283 & 2,250 & 45.7 \\
\hline 16 & 00 & 21.50 & 16.000 & .017 & .300 & 2,500 & 50.8 \\
\hline 16 & 01 & 22.50 & 16.017 & .017 & .317 & 2,500 & 50.8 \\
\hline 16 & 02 & 23.40 & 16.033 & .017 & .333 & 2,250 & 45.7 \\
\hline 16 & 03 & 24.20 & 16.050 & .017 & .350 & 2,000 & 40.6 \\
\hline 16 & 04 & 25.20 & 16.067 & .017 & .367 & 2,500 & 50.8 \\
\hline 16 & 05 & 26.10 & 16.083 & .017 & .383 & 2,250 & 45.7 \\
\hline 16 & 06 & 27.00 & 16.100 & .017 & .400 & 2,250 & 45.7 \\
\hline 16 & 07 & 27.90 & 16.117 & .017 & .417 & 2,250 & 45.7 \\
\hline 16 & 08 & 28.90 & 16.133 & .017 & .433 & 2,500 & 50.8 \\
\hline 16 & 09 & 29.80 & 16.150 & .017 & .450 & 2,250 & 45.7 \\
\hline 16 & 10 & 30.70 & 16.167 & .017 & .467 & 2,250 & 45.7 \\
\hline 16 & 11 & 31.50 & 16.183 & .017 & .483 & 2,000 & 40.6 \\
\hline 16 & 12 & 32.50 & 16.200 & .017 & .500 & 2,500 & 50.8 \\
\hline 16 & 13 & 33.30 & 16.217 & .017 & .517 & 1,999 & 40.6 \\
\hline 16 & 14 & 34.20 & 16.233 & .017 & .533 & 2,250 & 45.7 \\
\hline 16 & 15 & 35.00 & 16.250 & .017 & .550 & 1,999 & 40.6 \\
\hline 16 & 16 & 35.90 & 16.267 & .017 & .567 & 2,250 & 45.7 \\
\hline 16 & 17 & 36.70 & 16.283 & .017 & .583 & 2,000 & 40.6 \\
\hline 16 & 19 & 38.40 & 16.317 & .033 & .617 & 4,249 & 43.1 \\
\hline 16 & 20 & 39.20 & 16.333 & .017 & .633 & 2,000 & 40.6 \\
\hline 16 & 21 & 40.00 & 16.350 & .017 & .650 & 1,999 & 40.6 \\
\hline
\end{tabular}


Appendix 2-15. Infiltration data for site LG1._Continued

\begin{tabular}{|c|c|c|c|c|c|c|c|}
\hline \multicolumn{2}{|c|}{ Time } & \multirow[b]{2}{*}{ Tube (units) } & \multirow[b]{2}{*}{ Time } & \multicolumn{2}{|c|}{ Time } & \multicolumn{2}{|c|}{ Incremental } \\
\hline hrs & $\min$ & & & Interval (hrs) & Elapsed (hrs) & Volume (mL) & Velocity $(\mathrm{cm} / \mathrm{hr})$ \\
\hline 16 & 22 & 40.80 & 16.367 & 0.017 & 0.667 & 1,999 & 40.6 \\
\hline 16 & 23 & 41.60 & 16.383 & .017 & .683 & 2,000 & 40.6 \\
\hline 16 & 24 & 42.40 & 16.400 & .017 & .700 & 1,999 & 40.6 \\
\hline 16 & 25 & 43.20 & 16.417 & .017 & .717 & 2,000 & 40.6 \\
\hline 16 & 26 & 44.00 & 16.433 & .017 & .733 & 1,999 & 40.6 \\
\hline 16 & 27 & 44.80 & 16.450 & .017 & .750 & 1,999 & 40.6 \\
\hline 16 & 28 & 45.60 & 16.467 & .017 & .767 & 2,000 & 40.6 \\
\hline 16 & 29 & 46.40 & 16.483 & .017 & .783 & 1,999 & 40.6 \\
\hline 16 & 30 & 47.10 & 16.500 & .017 & .800 & 1,750 & 35.5 \\
\hline 16 & 31 & 47.90 & 16.517 & .017 & .817 & 1,999 & 40.6 \\
\hline 16 & 32 & 48.70 & 16.533 & .017 & .833 & 2,000 & 40.6 \\
\hline
\end{tabular}

\begin{tabular}{|c|c|}
\hline \multicolumn{2}{|c|}{ Penetration } \\
\hline Ring & Depth (inches) \\
\hline Inner & 3.0 \\
\hline Outer & 3.0 \\
\hline \multicolumn{2}{|c|}{ Constant water level } \\
\hline Ring & Depth (feet) \\
\hline Inner & 0.20 \\
\hline Outer & 0.20 \\
\hline
\end{tabular}

\begin{tabular}{cc}
\hline \multicolumn{2}{c}{ Water temperature } \\
\hline Temperature (degrees Celsius) & Time \\
\hline 17.0 & $16: 08$ \\
18.5 & $16: 16$ \\
19.0 & $16: 32$ \\
\hline \multicolumn{2}{c}{ Soil temperature } \\
\hline Temperature (degrees Celsius) & Depth (inches) \\
\hline 18.0 & 4.0 \\
\hline
\end{tabular}

Comments: None. 
58 Soils Infiltration Data for Selected Wyoming Watersheds, 1998-99

Appendix 2-16. Infiltration data for site LG2.

[hrs, hours; min, minutes; $\mathrm{mL}$, milliliters; $\mathrm{cm} / \mathrm{hr}$, centimeters per hour; --, no data; NA, not applicable]

\begin{tabular}{|c|c|c|c|c|c|c|c|}
\hline \multicolumn{2}{|c|}{ Time } & \multirow[b]{2}{*}{ Tube (units) } & \multirow[b]{2}{*}{ Time } & \multicolumn{2}{|c|}{ Time } & \multicolumn{2}{|c|}{ Incremental } \\
\hline hrs & $\min$ & & & Interval (hrs) & Elapsed (hrs) & Volume (mL) & Velocity $(\mathrm{cm} / \mathrm{hr})$ \\
\hline 16 & 59 & 0.60 & 16.983 & -- & -- & -- & -- \\
\hline 17 & 01 & 1.80 & 17.017 & 0.033 & 0.033 & 3,000 & 30.5 \\
\hline 17 & 02 & 2.80 & 17.033 & .017 & .050 & 2,500 & 50.8 \\
\hline 17 & 03 & 3.70 & 17.050 & .017 & .067 & 2,250 & 45.7 \\
\hline 17 & 04 & 4.80 & 17.067 & .017 & .083 & 2,750 & 55.8 \\
\hline 17 & 05 & 5.70 & 17.083 & .017 & .100 & 2,250 & 45.7 \\
\hline 17 & 06 & 6.50 & 17.100 & .017 & .117 & 2,000 & 40.6 \\
\hline 17 & 07 & 7.40 & 17.117 & .017 & .133 & 2,250 & 45.7 \\
\hline 17 & 08 & 8.10 & 17.133 & .017 & .150 & 1,750 & 35.5 \\
\hline 17 & 09 & 9.00 & 17.150 & .017 & .167 & 2,250 & 45.7 \\
\hline 17 & 10 & 9.50 & 17.167 & .017 & .183 & 1,250 & 25.4 \\
\hline 17 & 11 & 10.20 & 17.183 & .017 & .200 & 1,750 & 35.5 \\
\hline 17 & 12 & 10.90 & 17.200 & .017 & .217 & 1,750 & 35.5 \\
\hline 17 & 13 & 11.60 & 17.217 & .017 & .233 & 1,750 & 35.5 \\
\hline 17 & 14 & 12.40 & 17.233 & .017 & .250 & 2,000 & 40.6 \\
\hline 17 & 15 & 13.20 & 17.250 & .017 & .267 & 2,000 & 40.6 \\
\hline 17 & 16 & 14.00 & 17.267 & .017 & .283 & 2,000 & 40.6 \\
\hline 17 & 17 & 14.70 & 17.283 & .017 & .300 & 1,750 & 35.5 \\
\hline 17 & 18 & 15.50 & 17.300 & .017 & .317 & 2,000 & 40.6 \\
\hline 17 & 19 & 16.30 & 17.317 & .017 & .333 & 2,000 & 40.6 \\
\hline 17 & 20 & 17.10 & 17.333 & .017 & .350 & 2,000 & 40.6 \\
\hline 17 & 22 & 18.50 & 17.367 & .033 & .383 & 3,500 & 35.5 \\
\hline 17 & 24 & 20.00 & 17.400 & .033 & .417 & 3,750 & 38.1 \\
\hline 17 & 26 & 21.60 & 17.433 & .033 & .450 & 4,000 & 40.6 \\
\hline 17 & 28 & 23.00 & 17.467 & .033 & .483 & 3,500 & 35.5 \\
\hline 17 & 30 & 24.40 & 17.500 & .033 & .517 & 3,500 & 35.5 \\
\hline 17 & 32 & 25.80 & 17.533 & .033 & .550 & 3,500 & 35.5 \\
\hline 17 & 34 & 27.20 & 17.567 & .033 & .583 & 3,500 & 35.5 \\
\hline 17 & 36 & 28.60 & 17.600 & .033 & .617 & 3,500 & 35.5 \\
\hline 17 & 38 & 30.00 & 17.633 & .033 & .650 & 3,500 & 35.5 \\
\hline 17 & 40 & 31.30 & 17.667 & .033 & .683 & 3,250 & 33.0 \\
\hline 17 & 42 & 32.70 & 17.700 & .033 & .717 & 3,500 & 35.5 \\
\hline 17 & 43 & 33.40 & 17.717 & .017 & .733 & 1,749 & 35.5 \\
\hline 17 & 45 & 34.70 & 17.750 & .033 & .767 & 3,250 & 33.0 \\
\hline 17 & 47 & 36.00 & 17.783 & .033 & .800 & 3,249 & 33.0 \\
\hline 17 & 49 & 37.20 & 17.817 & .033 & .833 & 3,000 & 30.5 \\
\hline 17 & 51 & 38.50 & 17.850 & .033 & .867 & 3,249 & 33.0 \\
\hline 17 & 53 & 39.80 & 17.883 & .033 & .900 & 3,249 & 33.0 \\
\hline 17 & 55 & 41.10 & 17.917 & .033 & .933 & 3,250 & 33.0 \\
\hline
\end{tabular}


Appendix 2-16. Infiltration data for site LG2.-Continued

\begin{tabular}{|c|c|}
\hline \multicolumn{2}{|c|}{ Penetration } \\
\hline Ring & Depth (inches) \\
\hline Inner & 3.0 \\
\hline Outer & 3.0 \\
\hline \multicolumn{2}{|c|}{ Constant water level } \\
\hline Ring & Depth (feet) \\
\hline Inner & 0.20 \\
\hline Outer & 0.20 \\
\hline
\end{tabular}

\begin{tabular}{cc}
\hline \multicolumn{2}{c}{ Water temperature } \\
\hline Temperature (degrees Celsius) & Time \\
\hline 17.5 & $17: 08$ \\
17.5 & $17: 32$ \\
18.0 & $17: 55$ \\
\hline \multicolumn{2}{c}{ Soil temperature } \\
\hline Temperature (degrees Celsius) & Depth (inches) \\
\hline NA & NA \\
\hline
\end{tabular}

Comments: None. 
Appendix 2-17. Infiltration data for site LG3.

[hrs, hours; min, minutes; $\mathrm{mL}$, milliliters; $\mathrm{cm} / \mathrm{hr}$, centimeters per hour; --, no data]

\begin{tabular}{|c|c|c|c|c|c|c|c|}
\hline \multicolumn{2}{|c|}{ Time } & \multirow[b]{2}{*}{ Tube (units) } & \multirow[b]{2}{*}{ Time } & \multicolumn{2}{|c|}{ Time } & \multicolumn{2}{|c|}{ Incremental } \\
\hline hrs & $\min$ & & & Interval (hrs) & Elapsed (hrs) & Volume (mL) & Velocity $(\mathrm{cm} / \mathrm{hr})$ \\
\hline 9 & 23 & 1.60 & 9.383 & -- & -- & -- & -- \\
\hline 9 & 24 & 5.50 & 9.400 & 0.017 & 0.017 & 9,750 & 198.0 \\
\hline 9 & 25 & 8.40 & 9.417 & .017 & .033 & 7,250 & 147.2 \\
\hline 9 & 26 & 10.90 & 9.433 & .017 & .050 & 6,250 & 126.9 \\
\hline 9 & 27 & 12.90 & 9.450 & .017 & .067 & 5,000 & 101.5 \\
\hline 9 & 28 & 14.70 & 9.467 & .017 & .083 & 4,500 & 91.4 \\
\hline 9 & 29 & 16.40 & 9.483 & .017 & .100 & 4,250 & 86.3 \\
\hline 9 & 30 & 18.00 & 9.500 & .017 & .117 & 4,000 & 81.2 \\
\hline 9 & 31 & 19.60 & 9.517 & .017 & .133 & 4,000 & 81.2 \\
\hline 9 & 32 & 21.30 & 9.533 & .017 & .150 & 4,250 & 86.3 \\
\hline 9 & 33 & 22.90 & 9.550 & .017 & .167 & 3,999 & 81.2 \\
\hline 9 & 34 & 24.50 & 9.567 & .017 & .183 & 4,000 & 81.2 \\
\hline 9 & 35 & 26.10 & 9.583 & .017 & .200 & 4,000 & 81.2 \\
\hline 9 & 36 & 27.70 & 9.600 & .017 & .217 & 3,999 & 81.2 \\
\hline 9 & 37 & 29.40 & 9.617 & .017 & .233 & 4,250 & 86.3 \\
\hline 9 & 38 & 31.00 & 9.633 & .017 & .250 & 4,000 & 81.2 \\
\hline 9 & 39 & 32.60 & 9.650 & .017 & .267 & 4,000 & 81.2 \\
\hline 9 & 40 & 34.20 & 9.667 & .017 & .283 & 4,000 & 81.2 \\
\hline 9 & 41 & 35.70 & 9.683 & .017 & .300 & 3,750 & 76.1 \\
\hline 9 & 42 & 37.40 & 9.700 & .017 & .317 & 4,249 & 86.3 \\
\hline 9 & 43 & 38.90 & 9.717 & .017 & .333 & 3,750 & 76.1 \\
\hline 9 & 44 & 40.30 & 9.733 & .017 & .350 & 3,500 & 71.1 \\
\hline 9 & 45 & 41.80 & 9.750 & .017 & .367 & 3,750 & 76.1 \\
\hline 9 & 46 & 43.50 & 9.767 & .017 & .383 & 4,250 & 86.3 \\
\hline 9 & 47 & 45.00 & 9.783 & .017 & .400 & 3,750 & 76.1 \\
\hline 9 & 48 & 46.40 & 9.800 & .017 & .417 & 3,500 & 71.1 \\
\hline 9 & 49 & 48.00 & 9.817 & .017 & .433 & 4,000 & 81.2 \\
\hline 9 & 50 & 49.50 & 9.833 & .017 & .450 & 3,750 & 76.1 \\
\hline
\end{tabular}

\begin{tabular}{|c|c|}
\hline \multicolumn{2}{|c|}{ Penetration } \\
\hline Ring & Depth (inches) \\
\hline Inner & 2.3 \\
\hline Outer & 2.3 \\
\hline \multicolumn{2}{|c|}{ Constant water level } \\
\hline Ring & Depth (feet) \\
\hline Inner & 0.28 \\
\hline Outer & 0.20 \\
\hline
\end{tabular}

\begin{tabular}{cc}
\hline \multicolumn{2}{c}{ Water temperature } \\
\hline Temperature (degrees Celsius) & Time \\
\hline 12.5 & $09: 31$ \\
12.5 & $09: 41$ \\
12.5 & $09: 49$ \\
\hline \multicolumn{2}{c}{ Soil temperature } \\
\hline Temperature (degrees Celsius) & Depth (feet) \\
\hline 13.0 & 0.4 \\
\hline
\end{tabular}

Comments: None. 
Appendix 2-18. Infiltration data for site LG4.

[hrs, hours; min, minutes; $\mathrm{mL}$, milliliters; $\mathrm{cm} / \mathrm{hr}$, centimeters per hour; --, no data; NA, not applicable]

\begin{tabular}{|c|c|c|c|c|c|c|c|}
\hline \multicolumn{2}{|c|}{ Time } & \multirow[b]{2}{*}{ Tube (units) } & \multirow[b]{2}{*}{ Time } & \multicolumn{2}{|c|}{ Time } & \multicolumn{2}{|c|}{ Incremental } \\
\hline hrs & $\min$ & & & Interval (hrs) & Elapsed (hrs) & Volume (mL) & Velocity $(\mathrm{cm} / \mathrm{hr})$ \\
\hline 11 & 20 & 0.90 & 11.333 & -- & -- & -- & -- \\
\hline 11 & 21 & 1.70 & 11.350 & 0.017 & 0.017 & 2,000 & 40.6 \\
\hline 11 & 22 & 2.30 & 11.367 & .017 & .033 & 1,500 & 30.5 \\
\hline 11 & 23 & 4.30 & 11.383 & .017 & .050 & 5,000 & 101.5 \\
\hline 11 & 24 & 6.00 & 11.400 & .017 & .067 & 4,250 & 86.3 \\
\hline 11 & 25 & 7.60 & 11.417 & .017 & .083 & 4,000 & 81.2 \\
\hline 11 & 26 & 8.80 & 11.433 & .017 & .100 & 3,000 & 60.9 \\
\hline 11 & 27 & 10.20 & 11.450 & .017 & .117 & 3,500 & 71.1 \\
\hline 11 & 28 & 11.20 & 11.467 & .017 & .133 & 2,500 & 50.8 \\
\hline 11 & 29 & 12.30 & 11.483 & .017 & .150 & 2,750 & 55.8 \\
\hline 11 & 30 & 13.40 & 11.500 & .017 & .167 & 2,750 & 55.8 \\
\hline 11 & 31 & 14.40 & 11.517 & .017 & .183 & 2,500 & 50.8 \\
\hline 11 & 32 & 15.20 & 11.533 & .017 & .200 & 2,000 & 40.6 \\
\hline 11 & 34 & 17.10 & 11.567 & .033 & .233 & 4,750 & 48.2 \\
\hline 11 & 35 & 18.00 & 11.583 & .017 & .250 & 2,250 & 45.7 \\
\hline 11 & 36 & 18.90 & 11.600 & .017 & .267 & 2,250 & 45.7 \\
\hline 11 & 37 & 19.70 & 11.617 & .017 & .283 & 2,000 & 40.6 \\
\hline 11 & 38 & 20.50 & 11.633 & .017 & .300 & 2,000 & 40.6 \\
\hline 11 & 40 & 22.10 & 11.667 & .033 & .333 & 4,000 & 40.6 \\
\hline 11 & 42 & 23.60 & 11.700 & .033 & .367 & 3,750 & 38.1 \\
\hline 11 & 44 & 25.10 & 11.733 & .033 & .400 & 3,750 & 38.1 \\
\hline 11 & 46 & 26.40 & 11.767 & .033 & .433 & 3,249 & 33.0 \\
\hline 11 & 48 & 27.90 & 11.800 & .033 & .467 & 3,750 & 38.1 \\
\hline 11 & 50 & 29.30 & 11.833 & .033 & .500 & 3,500 & 35.5 \\
\hline 11 & 52 & 30.50 & 11.867 & .033 & .533 & 3,000 & 30.5 \\
\hline 11 & 54 & 31.90 & 11.900 & .033 & .567 & 3,500 & 35.5 \\
\hline 11 & 56 & 33.10 & 11.933 & .033 & .600 & 3,000 & 30.5 \\
\hline 11 & 58 & 34.40 & 11.967 & .033 & .633 & 3,249 & 33.0 \\
\hline 12 & 00 & 35.60 & 12.000 & .033 & .667 & 3,000 & 30.5 \\
\hline 12 & 03 & 37.40 & 12.050 & .050 & .717 & 4,499 & 30.5 \\
\hline 12 & 05 & 38.60 & 12.083 & .033 & .750 & 3,000 & 30.5 \\
\hline 12 & 07 & 39.70 & 12.117 & .033 & .783 & 2,750 & 27.9 \\
\hline 12 & 09 & 40.80 & 12.150 & .033 & .817 & 2,749 & 27.9 \\
\hline 12 & 12 & 42.40 & 12.200 & .050 & .867 & 4,000 & 27.1 \\
\hline 12 & 14 & 43.60 & 12.233 & .033 & .900 & 3,000 & 30.5 \\
\hline 12 & 16 & 44.60 & 12.267 & .033 & .933 & 2,500 & 25.4 \\
\hline 12 & 18 & 45.80 & 12.300 & .033 & .967 & 2,999 & 30.4 \\
\hline 12 & 20 & 46.80 & 12.333 & .033 & 1.000 & 2,500 & 25.4 \\
\hline 12 & 22 & 47.80 & 12.367 & .033 & 1.033 & 2,500 & 25.4 \\
\hline 12 & 24 & 48.80 & 12.400 & .033 & 1.067 & 2,500 & 25.4 \\
\hline
\end{tabular}


Appendix 2-18. Infiltration data for site LG4._-Continued

\begin{tabular}{|c|c|}
\hline \multicolumn{2}{|c|}{ Penetration } \\
\hline Ring & Depth (inches) \\
\hline Inner & 4.0 \\
\hline Outer & 4.0 \\
\hline \multicolumn{2}{|c|}{ Constant water level } \\
\hline Ring & Depth (feet) \\
\hline Inner & 0.20 \\
\hline Outer & 0.18 \\
\hline
\end{tabular}

\begin{tabular}{cc}
\hline \multicolumn{2}{c}{ Water temperature } \\
\hline Temperature (degrees Celsius) & Time \\
\hline 16.0 & $11: 34$ \\
16.5 & $11: 42$ \\
17.0 & $12: 14$ \\
\hline \multicolumn{2}{c}{ Soil temperature } \\
\hline Temperature (degrees Celsius) & Depth (inches) \\
\hline NA & NA \\
\hline
\end{tabular}

Comments: None. 
Appendix 2-19. Infiltration data for site DC1.

[hrs, hours; min, minutes; $\mathrm{mL}$, milliliters; $\mathrm{cm} / \mathrm{hr}$, centimeters per hour; --, no data]

\begin{tabular}{|c|c|c|c|c|c|c|c|}
\hline \multicolumn{2}{|c|}{ Time } & \multirow[b]{2}{*}{ Tube (units) } & \multirow[b]{2}{*}{ Time } & \multicolumn{2}{|c|}{ Time } & \multicolumn{2}{|c|}{ Incremental } \\
\hline hrs & $\min$ & & & Interval (hrs) & Elapsed (hrs) & Volume (mL) & Velocity $(\mathrm{cm} / \mathrm{hr})$ \\
\hline 9 & 28 & 0.40 & 9.467 & -- & -- & -- & -- \\
\hline 9 & 29 & 1.70 & 9.483 & 0.017 & 0.017 & 3,250 & 66.0 \\
\hline 9 & 30 & 3.60 & 9.500 & .017 & .033 & 4,750 & 96.4 \\
\hline 9 & 31 & 4.90 & 9.517 & .017 & .050 & 3,250 & 66.0 \\
\hline 9 & 32 & 6.00 & 9.533 & .017 & .067 & 2,750 & 55.8 \\
\hline 9 & 33 & 6.90 & 9.550 & .017 & .083 & 2,250 & 45.7 \\
\hline 9 & 34 & 7.70 & 9.567 & .017 & .100 & 2,000 & 40.6 \\
\hline 9 & 35 & 8.30 & 9.583 & .017 & .117 & 1,500 & 30.5 \\
\hline 9 & 36 & 8.90 & 9.600 & .017 & .133 & 1,500 & 30.5 \\
\hline 9 & 37 & 9.50 & 9.617 & .017 & .150 & 1,500 & 30.5 \\
\hline 9 & 38 & 10.00 & 9.633 & .017 & .167 & 1,250 & 25.4 \\
\hline 9 & 39 & 10.50 & 9.650 & .017 & .183 & 1,250 & 25.4 \\
\hline 9 & 40 & 10.90 & 9.667 & .017 & .200 & 1,000 & 20.3 \\
\hline 9 & 41 & 11.30 & 9.683 & .017 & .217 & 1,000 & 20.3 \\
\hline 9 & 42 & 11.50 & 9.700 & .017 & .233 & 499 & 10.1 \\
\hline 9 & 43 & 11.90 & 9.717 & .017 & .250 & 1,000 & 20.3 \\
\hline 9 & 44 & 12.20 & 9.733 & .017 & .267 & 749 & 15.2 \\
\hline 9 & 45 & 12.50 & 9.750 & .017 & .283 & 750 & 15.2 \\
\hline 9 & 46 & 12.80 & 9.767 & .017 & .300 & 750 & 15.2 \\
\hline 9 & 47 & 13.10 & 9.783 & .017 & .317 & 749 & 15.2 \\
\hline 9 & 48 & 13.30 & 9.800 & .017 & .333 & 500 & 10.2 \\
\hline 9 & 49 & 13.60 & 9.817 & .017 & .350 & 749 & 15.2 \\
\hline 9 & 50 & 13.90 & 9.833 & .017 & .367 & 750 & 15.2 \\
\hline 9 & 51 & 14.10 & 9.850 & .017 & .383 & 499 & 10.1 \\
\hline 9 & 52 & 14.30 & 9.867 & .017 & .400 & 500 & 10.2 \\
\hline 9 & 53 & 14.50 & 9.883 & .017 & .417 & 499 & 10.1 \\
\hline 9 & 54 & 14.70 & 9.900 & .017 & .433 & 499 & 10.1 \\
\hline 9 & 55 & 15.00 & 9.917 & .017 & .450 & 750 & 15.2 \\
\hline
\end{tabular}

\begin{tabular}{|c|c|}
\hline \multicolumn{2}{|c|}{ Penetration } \\
\hline Ring & Depth (inches) \\
\hline Inner & 3.0 \\
\hline Outer & 3.0 \\
\hline \multicolumn{2}{|c|}{ Constant water level } \\
\hline Ring & Depth (feet) \\
\hline Inner & 0.20 \\
\hline Outer & 0.18 \\
\hline
\end{tabular}

\begin{tabular}{cc}
\hline \multicolumn{2}{c}{ Water temperature } \\
\hline Temperature (degrees Celsius) & Time \\
\hline 18.0 & $09: 33$ \\
18.0 & $09: 31$ \\
17.0 & $09: 55$ \\
\hline \multicolumn{2}{c}{ Soil temperature } \\
\hline Temperature (degrees Celsius) & Depth (feet) \\
\hline 8.0 & 0.4 \\
\hline
\end{tabular}

Comments: Inner-ring water level increased at test end. 
Appendix 2-20. Infiltration data for site DC2.

[hrs, hours; min, minutes; $\mathrm{mL}$, milliliters; $\mathrm{cm} / \mathrm{hr}$, centimeters per hour; --, no data; NA, not applicable]

\begin{tabular}{|c|c|c|c|c|c|c|c|}
\hline \multicolumn{2}{|c|}{ Time } & \multirow[b]{2}{*}{ Tube (units) } & \multirow[b]{2}{*}{ Time } & \multicolumn{2}{|c|}{ Time } & \multicolumn{2}{|c|}{ Incremental } \\
\hline hrs & $\min$ & & & Interval (hrs) & Elapsed (hrs) & Volume (mL) & Velocity $(\mathrm{cm} / \mathrm{hr})$ \\
\hline 10 & 28 & 0.20 & 10.467 & -- & -- & -- & -- \\
\hline 10 & 29 & 2.30 & 10.483 & 0.017 & 0.017 & 5,250 & 106.6 \\
\hline 10 & 30 & 5.30 & 10.500 & .017 & .033 & 7,500 & 152.3 \\
\hline 10 & 31 & 7.00 & 10.517 & .017 & .050 & 4,250 & 86.3 \\
\hline 10 & 32 & 8.10 & 10.533 & .017 & .067 & 2,750 & 55.8 \\
\hline 10 & 33 & 9.00 & 10.550 & .017 & .083 & 2,250 & 45.7 \\
\hline 10 & 34 & 9.80 & 10.567 & .017 & .100 & 2,000 & 40.6 \\
\hline 10 & 35 & 10.50 & 10.583 & .017 & .117 & 1,750 & 35.5 \\
\hline 10 & 37 & 11.70 & 10.617 & .033 & .150 & 3,000 & 30.5 \\
\hline 10 & 38 & 12.20 & 10.633 & .017 & .167 & 1,250 & 25.4 \\
\hline 10 & 39 & 12.70 & 10.650 & .017 & .183 & 1,250 & 25.4 \\
\hline 10 & 40 & 13.20 & 10.667 & .017 & .200 & 1,250 & 25.4 \\
\hline 10 & 41 & 13.60 & 10.683 & .017 & .217 & 1,000 & 20.3 \\
\hline 10 & 42 & 14.00 & 10.700 & .017 & .233 & 1,000 & 20.3 \\
\hline 10 & 43 & 14.40 & 10.717 & .017 & .250 & 1,000 & 20.3 \\
\hline 10 & 44 & 14.70 & 10.733 & .017 & .267 & 749 & 15.2 \\
\hline 10 & 45 & 15.10 & 10.750 & .017 & .283 & 1,000 & 20.3 \\
\hline 10 & 46 & 15.40 & 10.767 & .017 & .300 & 750 & 15.2 \\
\hline 10 & 47 & 15.70 & 10.783 & .017 & .317 & 749 & 15.2 \\
\hline 10 & 48 & 16.00 & 10.800 & .017 & .333 & 750 & 15.2 \\
\hline 10 & 49 & 16.20 & 10.817 & .017 & .350 & 499 & 10.1 \\
\hline 10 & 50 & 16.40 & 10.833 & .017 & .367 & 499 & 10.1 \\
\hline 10 & 51 & 16.70 & 10.850 & .017 & .383 & 750 & 15.2 \\
\hline 10 & 52 & 16.90 & 10.867 & .017 & .400 & 499 & 10.1 \\
\hline 10 & 53 & 17.10 & 10.883 & .017 & .417 & 500 & 10.2 \\
\hline 10 & 54 & 17.40 & 10.900 & .017 & .433 & 749 & 15.2 \\
\hline 10 & 55 & 17.60 & 10.917 & .017 & .450 & 500 & 10.2 \\
\hline
\end{tabular}

\begin{tabular}{|c|c|}
\hline \multicolumn{2}{|c|}{ Penetration } \\
\hline Ring & Depth (inches) \\
\hline Inner & 3.3 \\
\hline Outer & 3.3 \\
\hline \multicolumn{2}{|c|}{ Constant water level } \\
\hline Ring & Depth (feet) \\
\hline Inner & 0.25 \\
\hline Outer & 0.25 \\
\hline
\end{tabular}

\begin{tabular}{cc}
\hline \multicolumn{2}{c}{ Water temperature } \\
\hline Temperature (degrees Celsius) & Time \\
\hline 18.0 & $10: 32$ \\
18.0 & $10: 46$ \\
18.0 & $10: 49$ \\
\hline \multicolumn{2}{c}{ Soil temperature } \\
\hline Temperature (degrees Celsius) & Depth (inches) \\
\hline NA & NA
\end{tabular}

Comments: Inner-ring water level increased at test end. 
Appendix 2-21. Infiltration data for site SP1.

[hrs, hours; min, minutes; $\mathrm{mL}$, milliliters; $\mathrm{cm} / \mathrm{hr}$, centimeters per hour; --, no data]

\begin{tabular}{|c|c|c|c|c|c|c|c|}
\hline \multicolumn{2}{|c|}{ Time } & \multirow[b]{2}{*}{ Tube (units) } & \multirow[b]{2}{*}{ Time } & \multicolumn{2}{|c|}{ Time } & \multicolumn{2}{|c|}{ Incremental } \\
\hline hrs & $\min$ & & & Interval (hrs) & Elapsed (hrs) & Volume (mL) & Velocity $(\mathrm{cm} / \mathrm{hr})$ \\
\hline 13 & 15 & 0.30 & 13.250 & -- & -- & -- & -- \\
\hline 13 & 17 & 5.80 & 13.283 & 0.033 & 0.033 & 13,750 & 139.6 \\
\hline 13 & 18 & 9.60 & 13.300 & .017 & .050 & 9,500 & 192.9 \\
\hline 13 & 19 & 12.00 & 13.317 & .017 & .067 & 6,000 & 121.8 \\
\hline 13 & 20 & 13.70 & 13.333 & .017 & .083 & 4,250 & 86.3 \\
\hline 13 & 21 & 15.00 & 13.350 & .017 & .100 & 3,250 & 66.0 \\
\hline 13 & 22 & 16.00 & 13.367 & .017 & .117 & 2,500 & 50.8 \\
\hline 13 & 23 & 17.00 & 13.383 & .017 & .133 & 2,500 & 50.8 \\
\hline 13 & 24 & 18.00 & 13.400 & .017 & .150 & 2,500 & 50.8 \\
\hline 13 & 25 & 19.10 & 13.417 & .017 & .167 & 2,750 & 55.8 \\
\hline 13 & 26 & 20.10 & 13.433 & .017 & .183 & 2,500 & 50.8 \\
\hline 13 & 27 & 21.00 & 13.450 & .017 & .200 & 2,250 & 45.7 \\
\hline 13 & 28 & 22.00 & 13.467 & .017 & .217 & 2,500 & 50.8 \\
\hline 13 & 29 & 23.00 & 13.483 & .017 & .233 & 2,500 & 50.8 \\
\hline 13 & 30 & 24.00 & 13.500 & .017 & .250 & 2,500 & 50.8 \\
\hline 13 & 31 & 25.00 & 13.517 & .017 & .267 & 2,500 & 50.8 \\
\hline 13 & 32 & 25.90 & 13.533 & .017 & .283 & 2,250 & 45.7 \\
\hline 13 & 33 & 26.90 & 13.550 & .017 & .300 & 2,500 & 50.8 \\
\hline 13 & 34 & 27.80 & 13.567 & .017 & .317 & 2,250 & 45.7 \\
\hline 13 & 35 & 28.70 & 13.583 & .017 & .333 & 2,250 & 45.7 \\
\hline 13 & 36 & 29.60 & 13.600 & .017 & .350 & 2,250 & 45.7 \\
\hline 13 & 37 & 30.50 & 13.617 & .017 & .367 & 2,250 & 45.7 \\
\hline 13 & 38 & 31.40 & 13.633 & .017 & .383 & 2,250 & 45.7 \\
\hline 13 & 39 & 32.20 & 13.650 & .017 & .400 & 2,000 & 40.6 \\
\hline 13 & 40 & 33.10 & 13.667 & .017 & .417 & 2,250 & 45.7 \\
\hline 13 & 41 & 34.00 & 13.683 & .017 & .433 & 2,250 & 45.7 \\
\hline 13 & 42 & 34.90 & 13.700 & .017 & .450 & 2,250 & 45.7 \\
\hline 13 & 43 & 35.70 & 13.717 & .017 & .467 & 2,000 & 40.6 \\
\hline 13 & 44 & 36.50 & 13.733 & .017 & .483 & 1,999 & 40.6 \\
\hline 13 & 45 & 37.40 & 13.750 & .017 & .500 & 2,250 & 45.7 \\
\hline 13 & 46 & 38.20 & 13.767 & .017 & .517 & 2,000 & 40.6 \\
\hline 13 & 47 & 39.00 & 13.783 & .017 & .533 & 1,999 & 40.6 \\
\hline 13 & 48 & 39.90 & 13.800 & .017 & .550 & 2,250 & 45.7 \\
\hline 13 & 49 & 40.70 & 13.817 & .017 & .567 & 2,000 & 40.6 \\
\hline 13 & 50 & 41.50 & 13.833 & .017 & .583 & 1,999 & 40.6 \\
\hline 13 & 51 & 42.30 & 13.850 & .017 & .600 & 1,999 & 40.6 \\
\hline 13 & 52 & 43.20 & 13.867 & .017 & .617 & 2,250 & 45.7 \\
\hline 13 & 53 & 44.30 & 13.883 & .017 & .633 & 2,749 & 55.8 \\
\hline 13 & 55 & 45.60 & 13.917 & .033 & .667 & 3,250 & 33.0 \\
\hline
\end{tabular}


Soils Infiltration Data for Selected Wyoming Watersheds, 1998-99

Appendix 2-21. Infiltration data for site SP1.-Continued

\begin{tabular}{lc}
\hline & Penetration \\
\hline \multicolumn{1}{c}{ Ring } & Depth (inches) \\
\hline Inner & 5.0 \\
Outer & 5.0 \\
\hline
\end{tabular}

\begin{tabular}{cc}
\hline \multicolumn{2}{c}{ Water temperature } \\
\hline Temperature (degrees Celsius) & Time \\
\hline 20.0 & $13: 19$ \\
21.0 & $13: 34$ \\
21.0 & $13: 53$ \\
\hline \multicolumn{2}{c}{ Soil temperature } \\
\hline Temperature (degrees Celsius) & Depth (feet) \\
\hline 9.5 & 0.4 \\
\hline
\end{tabular}

Comments: None. 
Appendix 2-22. Infiltration data for site SP2.

[hrs, hours; min, minutes; $\mathrm{mL}$, milliliters; cm/hr, centimeters per hour; --, no data; NA, not applicable]

\begin{tabular}{|c|c|c|c|c|c|c|c|}
\hline \multicolumn{2}{|c|}{ Time } & \multirow[b]{2}{*}{ Tube (units) } & \multirow[b]{2}{*}{ Time } & \multicolumn{2}{|c|}{ Time } & \multicolumn{2}{|c|}{ Incremental } \\
\hline hrs & $\min$ & & & Interval (hrs) & Elapsed (hrs) & Volume (mL) & Velocity $(\mathrm{cm} / \mathrm{hr})$ \\
\hline 14 & 34 & 0.10 & 14.567 & -- & -- & -- & -- \\
\hline 14 & 35 & 2.70 & 14.583 & 0.017 & 0.017 & 6,500 & 132.0 \\
\hline 14 & 36 & 4.50 & 14.600 & .017 & .033 & 4,500 & 91.4 \\
\hline 14 & 37 & 5.50 & 14.617 & .017 & .050 & 2,500 & 50.8 \\
\hline 14 & 38 & 6.20 & 14.633 & .017 & .067 & 1,750 & 35.5 \\
\hline 14 & 39 & 6.80 & 14.650 & .017 & .083 & 1,500 & 30.5 \\
\hline 14 & 40 & 7.30 & 14.667 & .017 & .100 & 1,250 & 25.4 \\
\hline 14 & 41 & 7.80 & 14.683 & .017 & .117 & 1,250 & 25.4 \\
\hline 14 & 42 & 8.40 & 14.700 & .017 & .133 & 1,500 & 30.5 \\
\hline 14 & 43 & 8.90 & 14.717 & .017 & .150 & 1,250 & 25.4 \\
\hline 14 & 44 & 9.40 & 14.733 & .017 & .167 & 1,250 & 25.4 \\
\hline 14 & 45 & 9.90 & 14.750 & .017 & .183 & 1,250 & 25.4 \\
\hline 14 & 46 & 10.30 & 14.767 & .017 & .200 & 1,000 & 20.3 \\
\hline 14 & 47 & 10.70 & 14.783 & .017 & .217 & 999 & 20.3 \\
\hline 14 & 48 & 11.10 & 14.800 & .017 & .233 & 1,000 & 20.3 \\
\hline 14 & 49 & 11.50 & 14.817 & .017 & .250 & 1,000 & 20.3 \\
\hline 14 & 50 & 11.90 & 14.833 & .017 & .267 & 1,000 & 20.3 \\
\hline 14 & 51 & 12.30 & 14.850 & .017 & .283 & 1,000 & 20.3 \\
\hline 14 & 52 & 12.70 & 14.867 & .017 & .300 & 999 & 20.3 \\
\hline
\end{tabular}

\begin{tabular}{|c|c|}
\hline \multicolumn{2}{|c|}{ Penetration } \\
\hline Ring & Depth (inches) \\
\hline Inner & 3.0 \\
\hline Outer & 3.0 \\
\hline \multicolumn{2}{|c|}{ Constant water level } \\
\hline Ring & Depth (feet) \\
\hline Inner & 0.20 \\
\hline Outer & 0.20 \\
\hline
\end{tabular}

\begin{tabular}{cc}
\hline \multicolumn{2}{c}{ Water temperature } \\
\hline Temperature (degrees Celsius) & Time \\
\hline 22.0 & $14: 42$ \\
22.0 & $14: 49$ \\
\multicolumn{2}{c}{ Soil temperature } \\
\hline Temperature (degrees Celsius) & Depth (inches) \\
\hline NA & NA \\
\hline
\end{tabular}

Comments: None. 
Appendix 2-23. Infiltration data for site SP3.

[hrs, hours; min, minutes; $\mathrm{mL}$, milliliters; $\mathrm{cm} / \mathrm{hr}$, centimeters per hour; --, no data; NA, not applicable]

\begin{tabular}{|c|c|c|c|c|c|c|c|}
\hline \multicolumn{2}{|c|}{ Time } & \multirow[b]{2}{*}{ Tube (units) } & \multirow[b]{2}{*}{ Time } & \multicolumn{2}{|c|}{ Time } & \multicolumn{2}{|c|}{ Incremental } \\
\hline hrs & $\min$ & & & Interval (hrs) & Elapsed (hrs) & Volume (mL) & Velocity $(\mathrm{cm} / \mathrm{hr})$ \\
\hline 15 & 23 & 0.30 & 15.383 & -- & -- & -- & -- \\
\hline 15 & 24 & 4.50 & 15.400 & 0.017 & 0.017 & 10,500 & 213.2 \\
\hline 15 & 25 & 8.20 & 15.417 & .017 & .033 & 9,250 & 187.8 \\
\hline 15 & 26 & 11.00 & 15.433 & .017 & .050 & 7,000 & 142.1 \\
\hline 15 & 27 & 13.40 & 15.450 & .017 & .067 & 6,000 & 121.8 \\
\hline 15 & 28 & 15.40 & 15.467 & .017 & .083 & 5,000 & 101.5 \\
\hline 15 & 29 & 17.40 & 15.483 & .017 & .100 & 5,000 & 101.5 \\
\hline 15 & 30 & 19.20 & 15.500 & .017 & .117 & 4,500 & 91.4 \\
\hline 15 & 31 & 21.00 & 15.517 & .017 & .133 & 4,500 & 91.4 \\
\hline 15 & 32 & 22.70 & 15.533 & .017 & .150 & 4,250 & 86.3 \\
\hline 15 & 33 & 24.40 & 15.550 & .017 & .167 & 4,250 & 86.3 \\
\hline 15 & 34 & 26.00 & 15.567 & .017 & .183 & 4,000 & 81.2 \\
\hline 15 & 35 & 27.60 & 15.583 & .017 & .200 & 4,000 & 81.2 \\
\hline 15 & 36 & 29.20 & 15.600 & .017 & .217 & 3,999 & 81.2 \\
\hline 15 & 37 & 30.80 & 15.617 & .017 & .233 & 4,000 & 81.2 \\
\hline 15 & 38 & 32.40 & 15.633 & .017 & .250 & 3,999 & 81.2 \\
\hline 15 & 39 & 33.80 & 15.650 & .017 & .267 & 3,500 & 71.1 \\
\hline 15 & 40 & 35.30 & 15.667 & .017 & .283 & 3,750 & 76.1 \\
\hline 15 & 41 & 36.80 & 15.683 & .017 & .300 & 3,750 & 76.1 \\
\hline 15 & 42 & 38.20 & 15.700 & .017 & .317 & 3,500 & 71.1 \\
\hline 15 & 43 & 39.70 & 15.717 & .017 & .333 & 3,750 & 76.1 \\
\hline 15 & 44 & 41.10 & 15.733 & .017 & .350 & 3,500 & 71.1 \\
\hline 15 & 45 & 42.50 & 15.750 & .017 & .367 & 3,500 & 71.1 \\
\hline 15 & 46 & 43.80 & 15.767 & .017 & .383 & 3,249 & 66.0 \\
\hline 15 & 47 & 45.10 & 15.783 & .017 & .400 & 3,250 & 66.0 \\
\hline 15 & 48 & 46.50 & 15.800 & .017 & .417 & 3,500 & 71.1 \\
\hline 15 & 49 & 47.80 & 15.817 & .017 & .433 & 3,249 & 66.0 \\
\hline
\end{tabular}

\begin{tabular}{|c|c|}
\hline \multicolumn{2}{|c|}{ Penetration } \\
\hline Ring & Depth (inches) \\
\hline Inner & 3.0 \\
\hline Outer & 3.0 \\
\hline \multicolumn{2}{|c|}{ Constant water level } \\
\hline Ring & Depth (feet) \\
\hline Inner & 0.20 \\
\hline Outer & 0.16 \\
\hline
\end{tabular}

\begin{tabular}{cc}
\hline \multicolumn{2}{c}{ Water temperature } \\
\hline Temperature (degrees Celsius) & Time \\
\hline 20.0 & $15: 29$ \\
20.5 & $15: 40$ \\
\multicolumn{2}{c}{ Soil temperature } \\
\hline Temperature (degrees Celsius) & Depth (inches) \\
\hline NA & NA \\
\hline
\end{tabular}

Comments: None. 